Portland State University

PDXScholar

$1-1-1981$

\title{
Explorations in the development of a descriptive model of strategic business planning
}

Laura Williamson Doyle

Portland State University

Follow this and additional works at: https://pdxscholar.library.pdx.edu/open_access_etds Let us know how access to this document benefits you.

\section{Recommended Citation}

Doyle, Laura Williamson, "Explorations in the development of a descriptive model of strategic business planning" (1981). Dissertations and Theses. Paper 789.

https://doi.org/10.15760/etd.789

This Dissertation is brought to you for free and open access. It has been accepted for inclusion in Dissertations and Theses by an authorized administrator of PDXScholar. Please contact us if we can make this document more accessible: pdxscholar@pdx.edu. 
EXPLORATIONS IN THE DEVELOPMENT OF A DESCRIPTIVE MODEL OF STRATEGIC BUSINESS PLANNING

by

Laura Williamson Doyie

A dissertation submitted in partial fulfillment of the requirements for the degree of

DOCTOR OF PHILOSOPHY

in

SYSTEMS SCIENCE

Portland State University

(C) 1981 Laura Williamson Doyle 
TO THE OFFICE OF GRADUATE STUDIES AIID IIESEARC!:

The meabers of the Cownittee approve tie cissertation of Laura Villiaruson Dojle presented February 23, 1901.
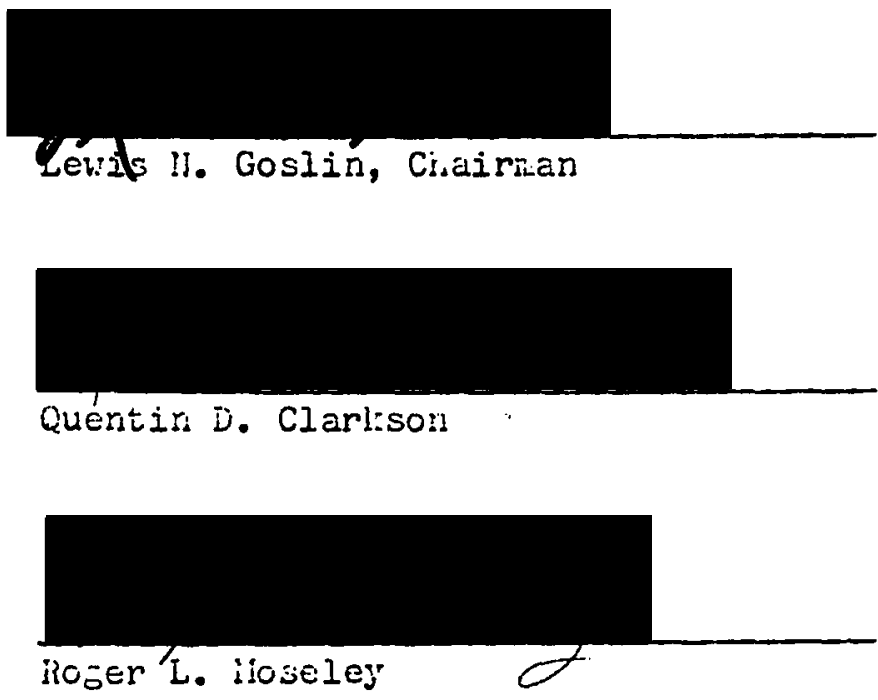

APPROVED:

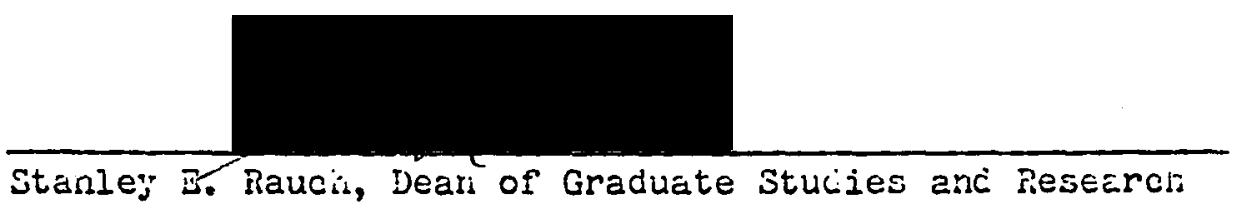


AN ABSTKACT OF THE DISSERTATIOH of Laura Williamson Doyle for the Doctor of Philosophy in Systems Science presented February 23, 1981.

Title: Explorations in the Development of a Descriptive lodel of Strategic Business Planning

APPROVED BY MEHBERS OF THE DISSERTATION COMIITTEE:
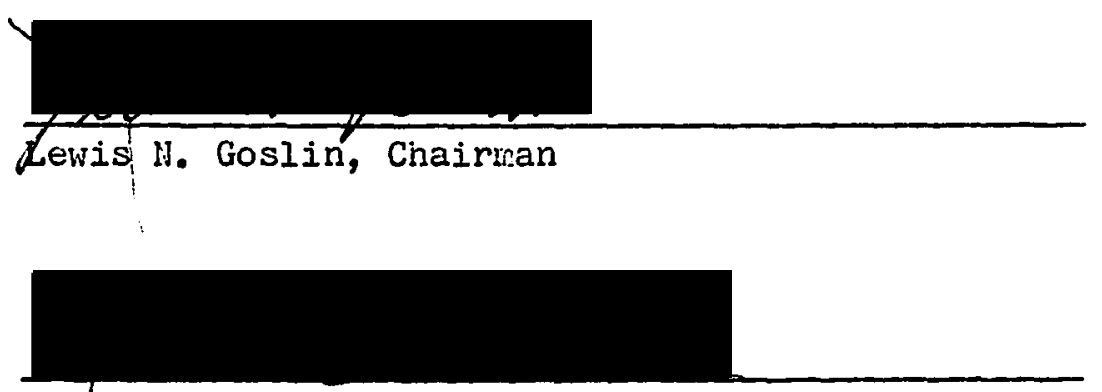

Quentin D. Clarkson

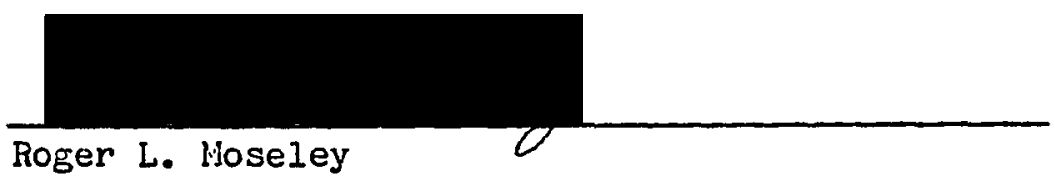

The intent of this exploratory case study was:

1) to compare a model of expected formal business plan content with the content of actual business plans developed within a single company,

2) to develop a modified model of formal business plan content which recognizes organizational influences on plan content,

3) to propose. a method for evaluating business plans based on this modified model. 
The firm studied was Fast Delta Corporation, a "Fortune 500" multidivisional manufacturing company in a high technology industry. The business plan content analyzed in this study was produced through a planning system similar to those implemented by other multidivisional companies.

In this study, planning by middle managers rather than top management was the primary focus. The study method was based on the analysis of formal plan content rather than direct observation or inquiry about the planning process.

Study steps included:

1) test of coodness of fit between a simple model of expected business plan content and the actual content of business plans produced through the Fast Delta Corporation planning system.

2) analysis of deviations of the actual content from the expected content model. This analysis included comparison of actual formal plan content with non-content characteristics of the formal plans, with the content of business strategy case studies from other firus, and with the the content of Fast Delta Corporation managers' responses to case studies in business strategy.

The results of this study showed that Fast Delta Corporation formal business plan content was influenced by several factors. These included short-term corporate-wide concerns; shared assumptions among managers about the strengths and limitations of the study firm; and constraints on strategy which nay be characteristic of other firms with similar structure, at a similar life cycle stage, or within the same industry. 
From these results a modified model of business plan content was developed which considered these influences. The validity of this model suggests that the plan analysis techniques used in this study were effective techniques for identifying the planning assurptions which underlie business plan content produced through a firm's formal business plannine syster.

The results and conclusions of this study are significant for top managenent, middle management, corporate planning staff, and those doin: research in strategic planning. 


\section{ACKNOWLEDGERENTS}

I wish to thank Drs. Bellerby, Clarkson, Goslin, and Moseley for their suggestions on the design and presentation of the dissertation. I wish to thank Drs. Linstone, Maruyama, and Sahal for the ideas they've presented through the Systems Science Program which I was able to draw on in the preparation of this dissertation. Tom Long and Cal Smith of Fast Delta Corporation deserve my gratitude for their interest in this project. Finally, my deepest appreciation to my husband for his patience, support, and encouragement in this long-term project. 
TABLE OF CONTENTS

PAGE

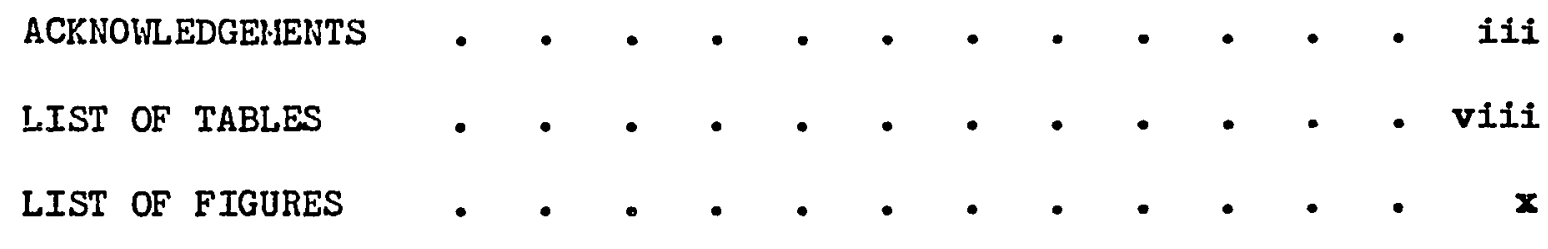

CHAPTER

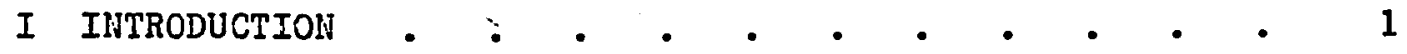

Background, Purpose and Significance of this Study - 1

Backeround

Purpose

Significance

Overview of the Hodel of Expected Plan Content . . 4

Description of the Expected Content Hodel

Objections to the Expected Content hodel

Intent of this Study

Description of the Study Firm . . . . . . 12

Description of Business Planning at The

Corporation . . . . . . . . . . 16

Limitations of this Study . . . . . . . 20

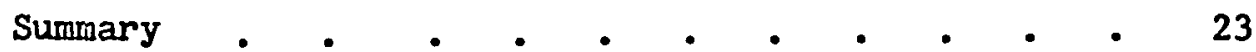

II REVIEW OF THE LITERATURE - • • • • • • • • • • 25

Expected Content of Formal Business Plans . . $\quad 25$

Corporate Strategy and Strategic Business

Plan Content

Normative Hodels of Strategic Business Plan

Content

Implications of Basic Content lodel for

Planning Process 


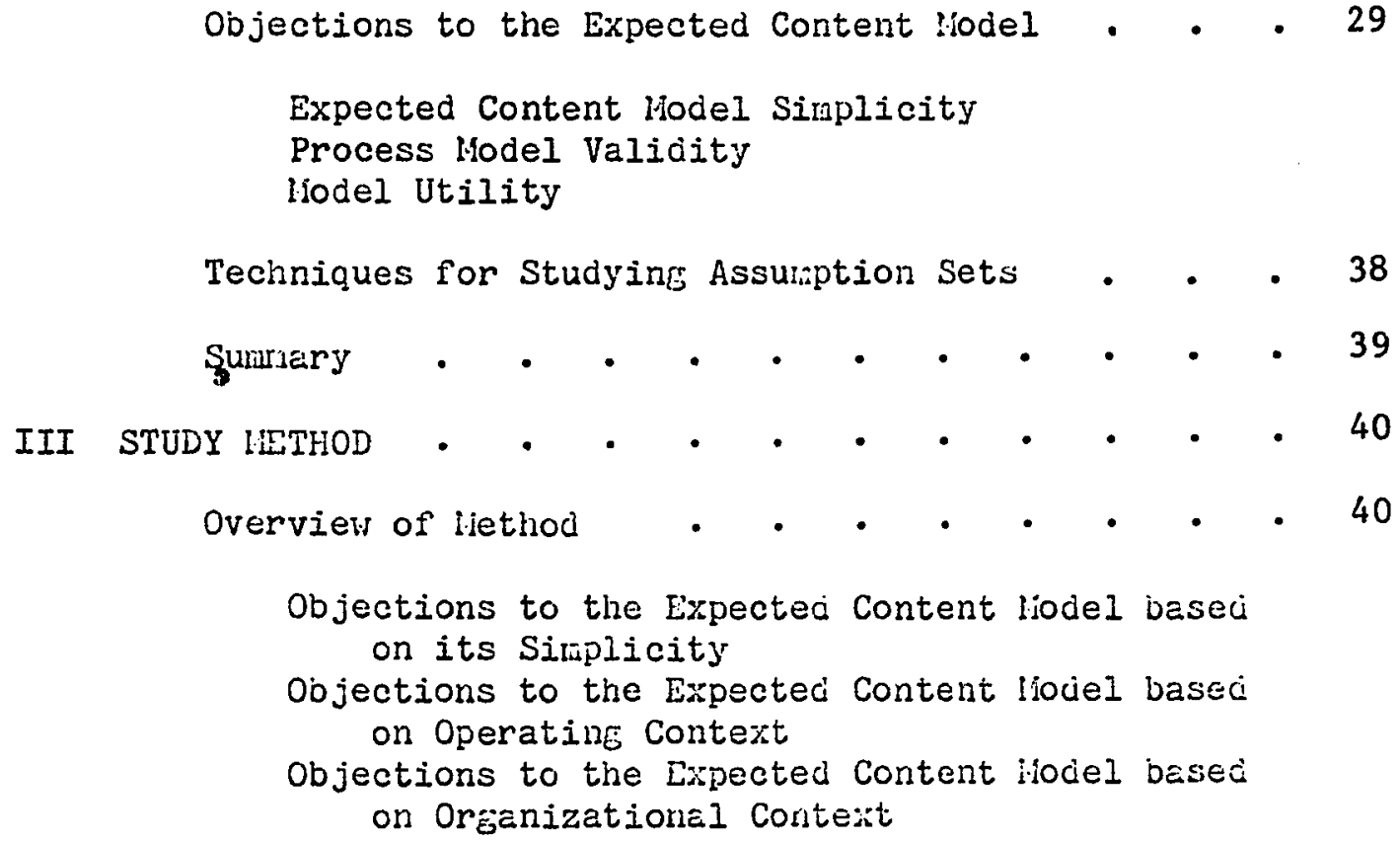

Objections to the Expected Content liodel based on its Sirplicity

Oojections to the Expected Content lociel based on Operating Context

Objections to the Expected Content liodel based on Organizational Context

Hodel Conparison: Expected Content hoclel vs Actual Strate;ic Plan Content

Variable Selection

Variable Coding

Data Tabulation

Data Analysis

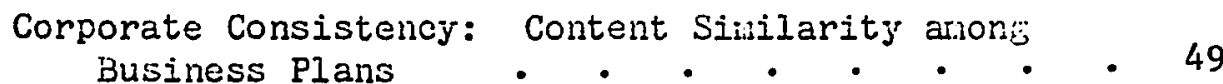

Rationale for Sirilarity Coeficient

Cálculation

Similarity Coefficient Calculation

Factor Analysis: Identifyinğ Couplex Components of Strategy

in Complex Components of

Non-Content Descriptors of Corporate Plans . . . 53

Planning Exercise: Plannine Process vs Plannins Losic

Planning Exercise Participants

Questionnaire Developnent: Part A and Part B Adninisterinï Questionaires 
Coding Questionnaire Jesionites

Analysis of Questionnaire Reslitts

Relative Corporate Consistency: Cowparison of Formal Plan Content vs Business Case Study Content .

Case Study Selection

Differences Between Case Studies and Formal Plans

Similarity Coefficient Calculation

Planning Exercise: Planninê Lo

Professional Characteristics

Sumary • • • • • • • • • • • • 62

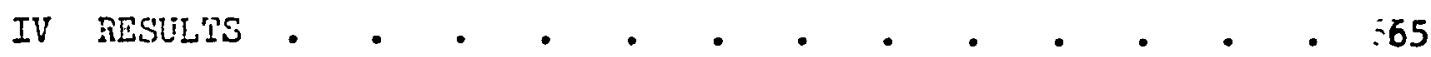

Goodness of Fit Test: Expected Content liodel vs Actual

Plan Content . . . . . . . . 65

Corporate Consistency: Sililarity Coerificients Por

Corporate Plans • . . . . . . • 68

Strateric Factors: Factor Analysis OA Plan Content . 71

lion-Contert Descriptors: Plan Characteristics anc:

Plan Content

Planning Exercise: Plamninis Process and Plannin: LoGic $•$ •

Relative Corporate Consisteney: Sililarity aron; Business Case Studies vs Sirilarity diloü For:ial Plans

Plannin̈ Exercise: Hanajers' Projessiolial

Characteristics vs Planrinir Logic . . . .

Content Variables and lianajers' Characteristics Sibilarity Anong ijanagers

Sumnary

V SULIARY, CONCLUSIOHS AHD RECOHHEZDATIOHS $\quad$ • • $\quad$ • 97

Sunwary

Pattern of Strategic Logic Role of Current Activities 
vii

CHAPTER

PAGE

Organizational Inpacts on Plan

Content

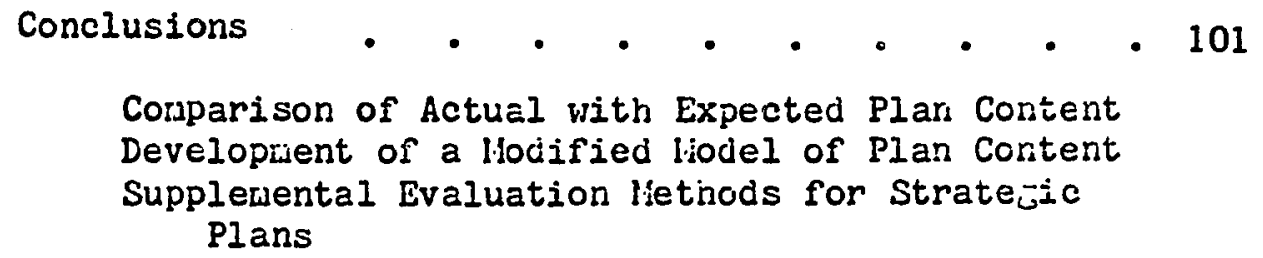

Recomendations

- 110

Top Yanagewent

liidcle lianagenent

Corporate Piannine Staff

For Further Stuciy

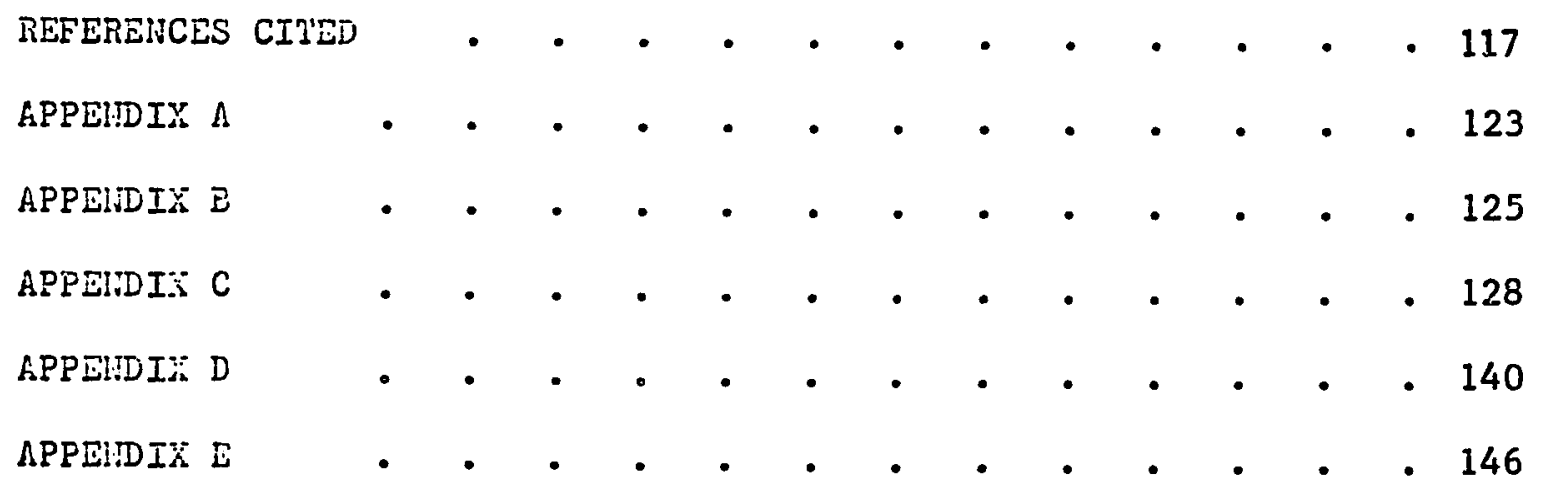




\section{LIST OF TABLES}

TABLE

PAGE

I Summary of Key Variables which Characterize the Expected Content Kodel • • • • • • • $\quad$ - 7

II Sumnary of Non-Content Variables Describing Plans • . 54

III Variables Used to Describe Professional Experience of Questionnaire Respondents . $\quad . \quad . \quad . \quad$. 63

IV Sumnary of Content Variable Pairs with Significant Joint Frequencies • • • • • • • • 66

V Comparison of Similarity Coefficients under Agreement and Disagreement for Condition and Action Variables for Formal Plans • • • • • • 69

VI Summary of Relative Agreement-Disagreement Score

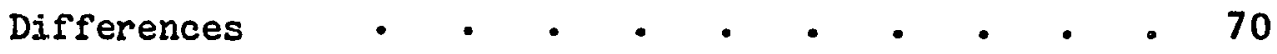

VII Results of Factor Analysis of Plan Content - • - $\quad 72$

VIII Content Variables Significantly Associated with Plan

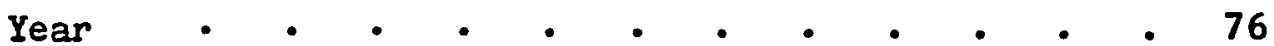

IX Content Variables Significantly Associated with Past Performance and Performance Forecasts - • . $\quad 77$

X Comparison of Part A Results with Basic Model and with

Formal Plan Results $\quad$. . . . . . 80

XI Comparison of Part B Results with Basic Model and with 
Eorwal Plan Results • • • • • • • • 80

XII Comparison of Similarity Coeficicients under föreenent and Disagreewent for Condition Variables between Fornal Plans anci Case Studies . $\quad$ - . . $\quad$ - 83 XIII Comparison $0 \hat{i}$ Sinilarity Coefficients under AGreenent and Disabreenent for Concition Variables between Formal Plans and Case Studies . . . . . 84

riv Suniary of Relative Agreenent-Disagreenent Score Differences • • • • • • • • • • • 85

yV Sumary of Content Variables Significantly Felated with Lenetir of Service • • • • • • • • • 88

XVI Sumary of Content Variables Significantiy tielated vith Functional Experience - • • • • • • • 90

XVII Sunitary ổ Content Variables Sionificantly Related iiti

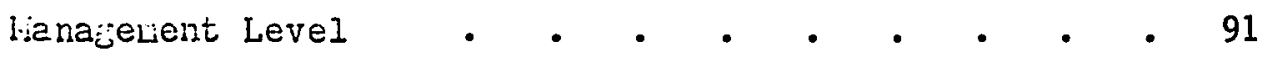
XVIII Results of Sirilarity Coesficient Calculations for Sub-Groups of lầajers • • • • • • • • • 93 


\section{LIST OF FIGURES}

FIGUPE

1. Sunizary of Business Researcin as the Expected Content líodel - 6

2. Conparison of Fast Delta Corporation liulti-divisional

Structure with General lulti-divisional Structure . . 15

3. Overviek of Strategic Planini Process Illustratine:

Three Kej Features • • • . • • • . 18

4. Overvie: of Fast Delta Corporation Strategic Plannine

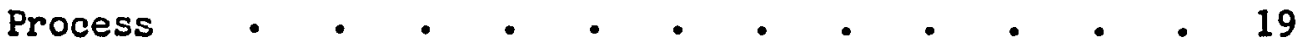

5. Overviev of Strategic Plaming Process for Mionentui:

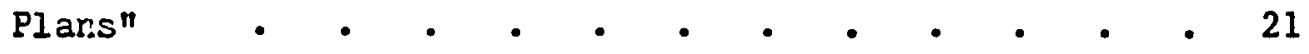

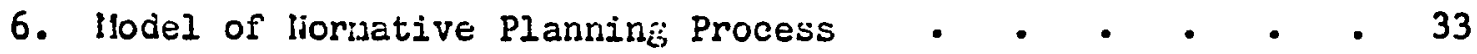

7. Kodel of liodified Planning Process ․ . . . . . 33

8. Flow Chart Subiarizing Study liethod • • • • • • 41

9. Comparison of Factor Analysis Results witin the Basic

lodel fror Figure 1 - . • • • • • • 73

10. Hodified lodel of Forwal Business Plan Content • • • 103

11. Hatrix of Alternative Approaches to Strategic Logic

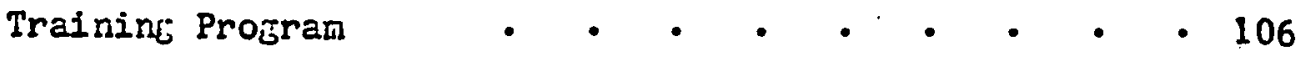




\section{CHAPTER I}

\section{INTRODUCTIOH}

Topics covered in this chapter include: background, purpose and significance of this study, overview of a nodel of expected strategic plan content, description of the study firn, description of the business planning process at the study firn, and limitations of this study.

$$
\text { BACKGROUIND, PURPOSE AIID SIGNIFICANCE OF THIS STUDY }
$$

\section{Background}

During the past 15 years, botin process and content nodels of stratefic planning (See Elossary, Appendix A, p. 123) have been developed which assume that ortanizations and their plans and activities can be evaluated in terms of efficiency or rationality. These models are reviewed in the first section of Chapter II (p. 24).

These models have been widely adoptec and inplenented in larie complex business organizations despite the simplistic assunptions on which they are based. lanagers have learned to rely on these models in their attempts at rational achievement and control and simplification of their increasingly complex environments. (Business Heek Deceuber 18, 1978, 62) At the same time, other models of organization activities as problem-solving efforts have been developed. These may be more descriptive of actual behavior under the ambiguous values and incouplete 
knowledge which characterize strategic business planning. These nodels have not been used explicitly in the design and analysis of fornal planning systems. (Sarrazin 1978) The second section of Chapter II ( $p$. 27), discusses three major objections to the simple strategy evaluation models and several alternative perspectives on strategy settinc which are based on organizational behavior models.

\section{Purpose}

The objectives of this exploratory study were threefold:

1) to compare a mociel of expected plan content with the actual business plan content developed in the study firm,

2) to develop a modified model of forwal plan content winich recosnizes organizational influences on pian cortent,

3) to propose a methoc for evaluating business plan content based on this modified model which can be used at The Fast Delta Corporation and other sirilar companies.

The preliminary step in this exploratory study vas a couparison of the content of the business plans produced through the formal plannine systed at Fast Delta Corporation (The Corporation) with an expected content model. The sirilarity of the plannine system at Fast Delta Corporation to those implemented by other multidivisional decentralized corporations is discussed in the following sections of this chapter (p. 4).

\section{Sisnificance}

The chief reason for attempting such a model building effort was the potential for improving the effectiveness of current decentralized 
strategic planning systems. Developing a nore accurate or complete model of business plan content would:

1) provide adoitional insights which can aid middle manazers in the development of business strategy and top managers in the developwent of corporate stratefic direction.

2) provide guidance to the corporate staff who design and implement planning processes by maling explicit the inpact of $a$ particular organization's characteristics and limits on its forwel plan content.

3) facilitate the evaluation of information conveyed throush formal plans. This is important for both staff and top management in evaluating plans and for top manarement in making decisions based on plans.

This model building exercise is unique in several ways:

1) The prinary focus of this study is the content of business unit plans developed trrough the formal decentralized planning system of a single large multinational, multidivision, high-tecinology industrial products manufacturer. This focus is based on two considerctions:

a) that the planning process and plannine logic can be deduced from the analysis of plan content; and,

b) that in a decentralized "bottom-up" planning systen corporate strategy appears not as a single top managerient business plan, but as a portfolio of business investment opportunities described by the plans of business units.

This approach is different from most descriptive studies of strategic business planning in that: 
a) most studies are based on the direct observation of plannine activities or on interviews with those involved in decision-wakin̈; and

b) most studies of strategic business planning focus on the role and activities of top managewent. The new and significant role of middle managers as entrepreneurs and strategic planners has only recently been noted and comented on. (Business Heek December 18, 1978 , 62)

2) This study attempts to malse deductions about the inpact of non-fomal planning logic on formal plannin̈ logic. A Lajor preaise behind this nodel buildine effort is that the organizational problen solving activities inpact the results or content of the planning process in consistent ways. These inpacts can be neasured in terus of deviations from a nodel of expected plan content. The particular deviations can be studied further for regular patterns. liost stuaies in strategic planning have been efforts in nornative rather than descriptive model building; or, they have been aired at building more effective content nodels of successful business strategy which better characterize marketplace laws. Descriptive studies of stratejic business planning have Eenerally been confined to anecaotal illustration of planning concepts or to assessments of the status and effectiveness of nomative planning systems in selected Eroups of companies.

\section{OVERVIEU OF THE MODEL OF EXPECTED PLAN CONTEHT}

\section{Description of the Expected Content liodel}

The expected content model must be based on the contingency theory of business strategy. This theory assumes that since the organization's 
objective is survival, business organizations adapt in consistent predictable ways to environmental conditions by adjusting their survival strategy or business stratezy. (Hofer, 1975)

Contingency theory suggests that a business plan can be effectively analyzed as a set of assunptions about conditions and a set of proposed actions or strate $\mathrm{Ey}$. Under certain conditions, certain action sets are wore likely than others to result in organization survival or success. (Hofer 1975) The proposed expected content model sumarizes associations between condition assumptions and proposed actions which have been identified by business researchers as resulting in success. This model is shown in Figure $1,(p .6)$, as a watrix associating a list of comon business conditions with actions fron a Iist of common business stratę̧ies. Table I (p. 7) provides references for these proposed associations among variables. While the two-dinensional matrix nodel of expected plan content shom in Fieure 1 (p. 6) is simplistic, it captures the essence of both the norlative planning process and the notion that business plans can be evaluatec in terms of consistency with general marketplace laws.(Schoeffler 1975, 1) This simple matrix provides a yardstick against which deviations in plan content can be measured. The simplicity of this model, however, prevents evaluation of deviations as "bad planninc".

Objections to Expected Content lodel

Descriptive literature on decision-nakine processes and informal interviews with practicing managers suggest two reasons why this nodeI may be neither valid nor useful in practical planning situations. Question of validity. Objections to the validity of this model 


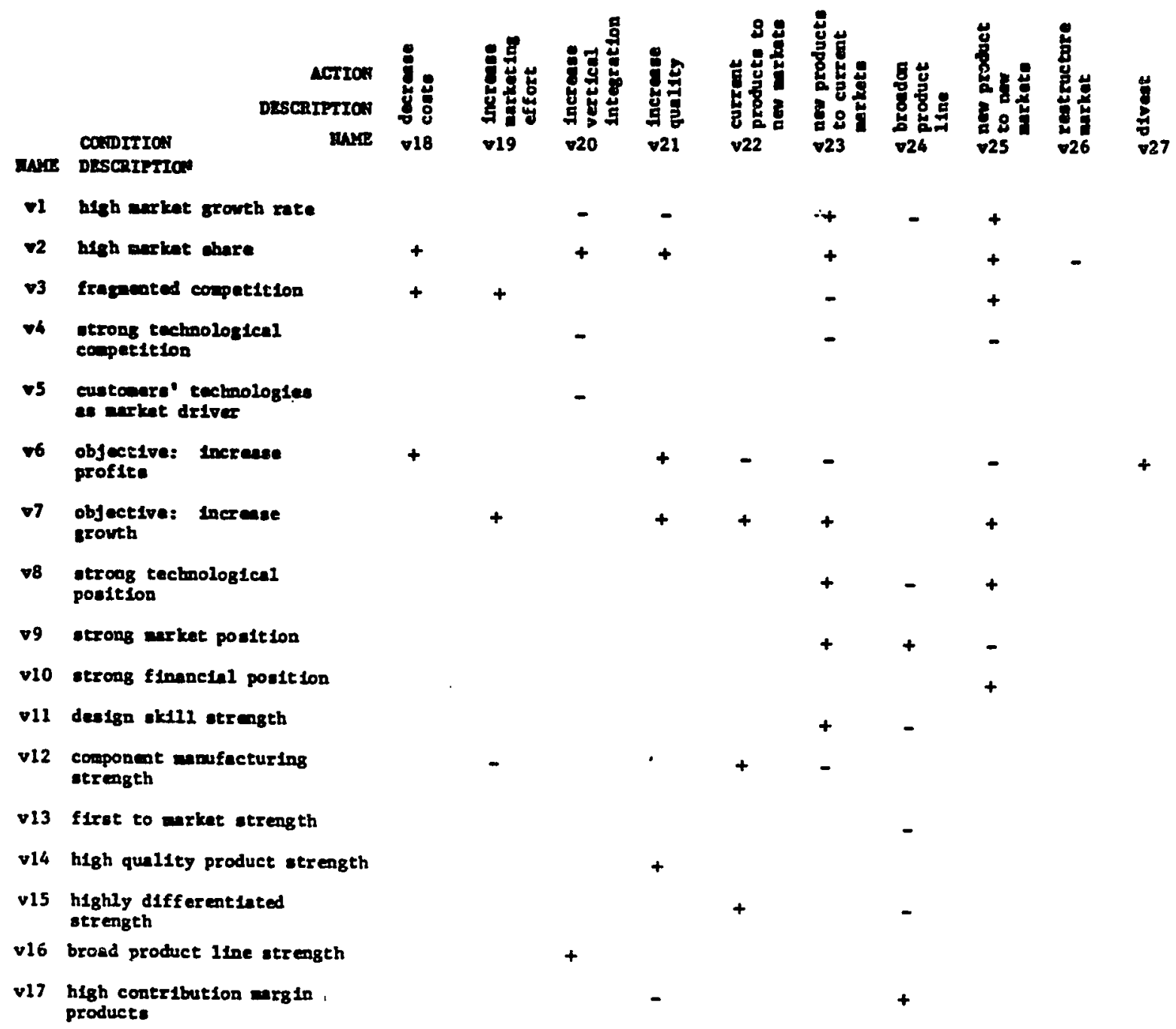

Figure 1. Sumnary of Business Literature as the Expected Content Model. This matrix illustrates the principle that: certain assumptions about business conditions and certain action plans should be consistently associated in business'plans. (+) indicates the pairs of variables used in this study whicin literature suggest should be associated. Variables are identified by the above numbers throughout the study and are described in Table $I,(p .7)$. Although the goodness of fit test used in this study addresses only positive associations between variables, variables which should be negatively associated are also shown above. (-) indicates variable pairs which should not occur together. 


\section{TABLE I}

SUMAARY OF KEY VARIABLES WHICH CHARACTERIZE THE EXPECTED CONTENT HODEL

\begin{tabular}{|c|c|}
\hline $\begin{array}{l}\text { NAME } \\
\text { I }\end{array}$ & $\begin{array}{l}\text { DESCRIPTION } \\
\text { high earket yrowth rate equal } \\
\text { or greater enan } 20 \% \text { year (reail }\end{array}$ \\
\hline$v 2$ & $\begin{array}{l}\text { hlgh market snare - equal or } \\
\text { greater than } 302 \text { in pursued } \\
\text { markets }\end{array}$ \\
\hline$\bullet 3$ & $\begin{array}{l}\text { Iragmented market - no } \\
\text { competitor has relative } \\
\text { marmet share greater than } \\
\text { 2r nearest }\end{array}$ \\
\hline 04 & $\begin{array}{l}\text { technological Innovation by } \\
\text { competitors is an important } \\
\text { conteloutor to markot chango }\end{array}$ \\
\hline$v 5$ & $\begin{array}{l}\text { customer technologlcal change } \\
\text { is an important contel butor to } \\
\text { market change }\end{array}$ \\
\hline
\end{tabular}

- ajor business objective is to Incraase proflicabliticy - up 202 over current level

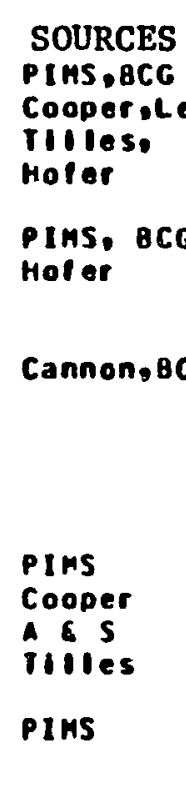

PINS

PIMS

PAIRED WITH
$\vee 23, \vee 25$

$\vee 20,021,023$. $\cup 18.019,025$

$\vee 19, v 22,418$

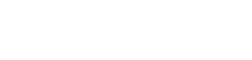

\section{EXAMPLE}

- The varket is estivated to grou in the future it j5x rate. prous mHP entersano Electronte Bustness. 9179. 0.75

- In theopenarmote..o. is enterenched ulen 002 varket share. irons buslaess pian 103

conpetitors are spectallzed to single segaent of the business. segment are often specialized. troar business pian 1205.

no correlations expected

- icroprocessor suppliter quichiy responded with alds to help the englecerso" froms "HP enters .." Electronic Business, 9179, D.75. no corrolations
expected

- inteducing les systom, MP is acdressing large and boonling merket enat resulted pron the develepment of tho alcroprocessor itself. fo ons mHP enters Eleceronlc Business, 9/79, D.75

$\vee 26,021,027$

mprofic goals ore just. as ambltious bring tnea up to the Indusery leaders 1177 pecurn on equityl. Proms aperkin Eimers Electronic Businesse 9179, 0.83.

19, 21,022, บ23,v25

- In ell. instrument cempantes accounted for $11 x$ of developaent sales lese yoas ... They could sell 402 in 1983 largely as a resule of HP"s eneryo" iroms "HP onters Eluctronis business, 9179, p.75. 
TABLE I (CONTINUED)

$\underset{y}{\text { NAME }}$ DESCRIPTION are ajor ousiness strength a arketing strongth - reputation serviceodistrioution

10

a major business serength is I tnancial, aolliey to support bissiness expansion

$\vee 11$

deslgn sklils, englneering knowledge are a significant strength

a significant strength is ability lo manufacture cosponents, vertical integration

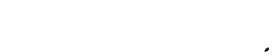

ช13

ablilty to or ing new product to market first is a business

serongth

\section{SOURCES}

PIHS, Cannon

CooperoAnsot

PAIRED WITH
$\vee 23, v 25$

$\bullet 23 \cdot v 24$

Cannon

Cooperosinsols

Arsof

PImS, Cannon a $\mathrm{S}$

\section{Cannon}

$A S$

$\checkmark 23$

$\checkmark 25$

$\checkmark 22$

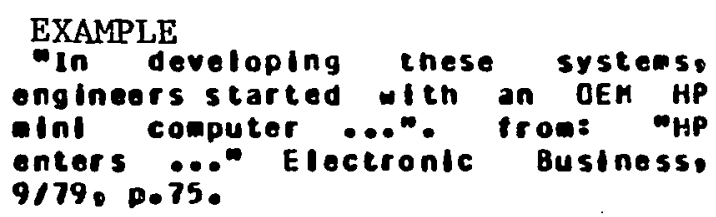

wany engineering manager who looks at the capltal Investment rogulied won't want co lock himself into a single sent-conductor aanutacturer when he can turn to two aajor instrusent manulacturor s." troms -HP enters ...". Electronic Business, 9/79, p.75.

mifa ealntains an oxtredely conservative Iinancial position ... that strong Inanclat position gives the the borroming pomer for future acquistelionse" from: wAS Con ...". Electronic Business. 6/79. P.62.

- these barriers come iron the cunaulative experlence of developing AIC7.

- M/A Con makes almost everyening trom sillcon waters to the sattellte subsystees that incorporate M/A loorlcaled chips $\ldots$... Markel analysts ... consider lis vortical integration o. strong points." irom: w/A Coe .... EN Electronic Business, 6/79, 0.62 .

PIMS, Cannon

Cooper

no correlations

expected 
TABLE I (CONTINUED)

\begin{tabular}{|c|c|c|c|c|}
\hline $\begin{array}{l}\text { NAME } \\
\square 14\end{array}$ & $\begin{array}{l}\text { DESCRIPTION } \\
\text { product IIne is characterized } \\
\text { by nigh qualiey rolative to } \\
\text { conpoticers - viewed as } \\
\text { business strengen }\end{array}$ & $\begin{array}{l}\text { SOURCES } \\
\text { PIMS }\end{array}$ & $\begin{array}{l}\text { PAIRED WITH } \\
\vee 21\end{array}$ & 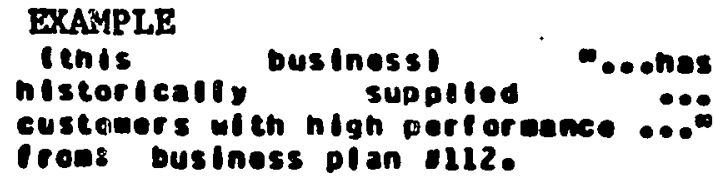 \\
\hline 115 & $\begin{array}{l}\text { product ilne is mighiy } \\
\text { differentiated from } \\
\text { competitars - offers } \\
\text { unique ieacuros ind inis is } \\
\text { vieued as business strengeh }\end{array}$ & $\begin{array}{l}\text { PInS } \\
\text { CoOper }\end{array}$ & $v 22$ & 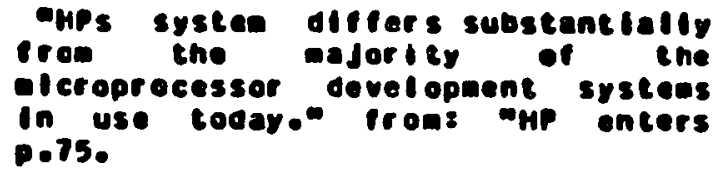 \\
\hline 116 & $\begin{array}{l}\text { - broad product I ine peovldes } \\
\text { an Important advantage }\end{array}$ & PIHS & $v 20$ & 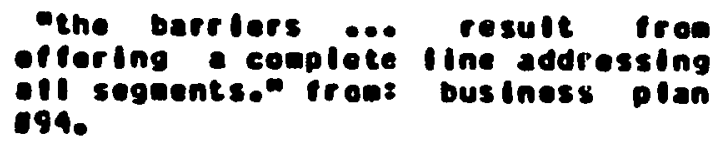 \\
\hline$\vee 17$ & $\begin{array}{l}\text { product conter loution argin } \\
\text { is relsetvety nigh }\end{array}$ & PIMS & $\checkmark 24$ & 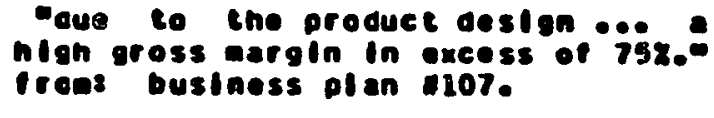 \\
\hline$\bullet 10$ & $\begin{array}{l}\text { actlon-strategy: decrease } \\
\text { anulacturing costs or } \\
\text { increase productivity }\end{array}$ & PINS,8CG & $v 2 \cdot v 3 \cdot v 6$ & 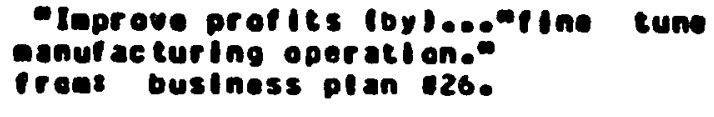 \\
\hline$\checkmark 19$ & $\begin{array}{l}\text { aetion-strategyi increase } \\
\text { marketinglsales effort }\end{array}$ & $\begin{array}{l}\text { PIms, Cannon } \\
\text { Cooper }\end{array}$ & 03,07 & 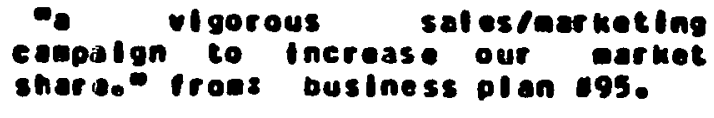 \\
\hline$v 20$ & $\begin{array}{l}\text { action-strategyz increase } \\
\text { vertical integration } \\
\text { lioruard or oackward }\end{array}$ & PINS & 02,016 & 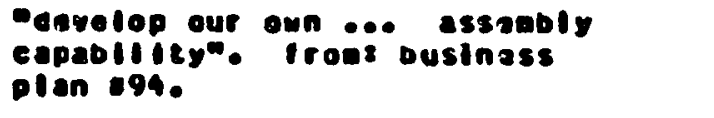 \\
\hline .21 & $\begin{array}{l}\text { Increase percelved product } \\
\text { quality }\end{array}$ & PIns & $\vee 2, \cup 6, v 7, v 14$ & 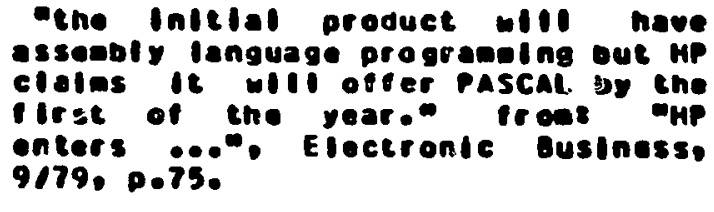 \\
\hline
\end{tabular}




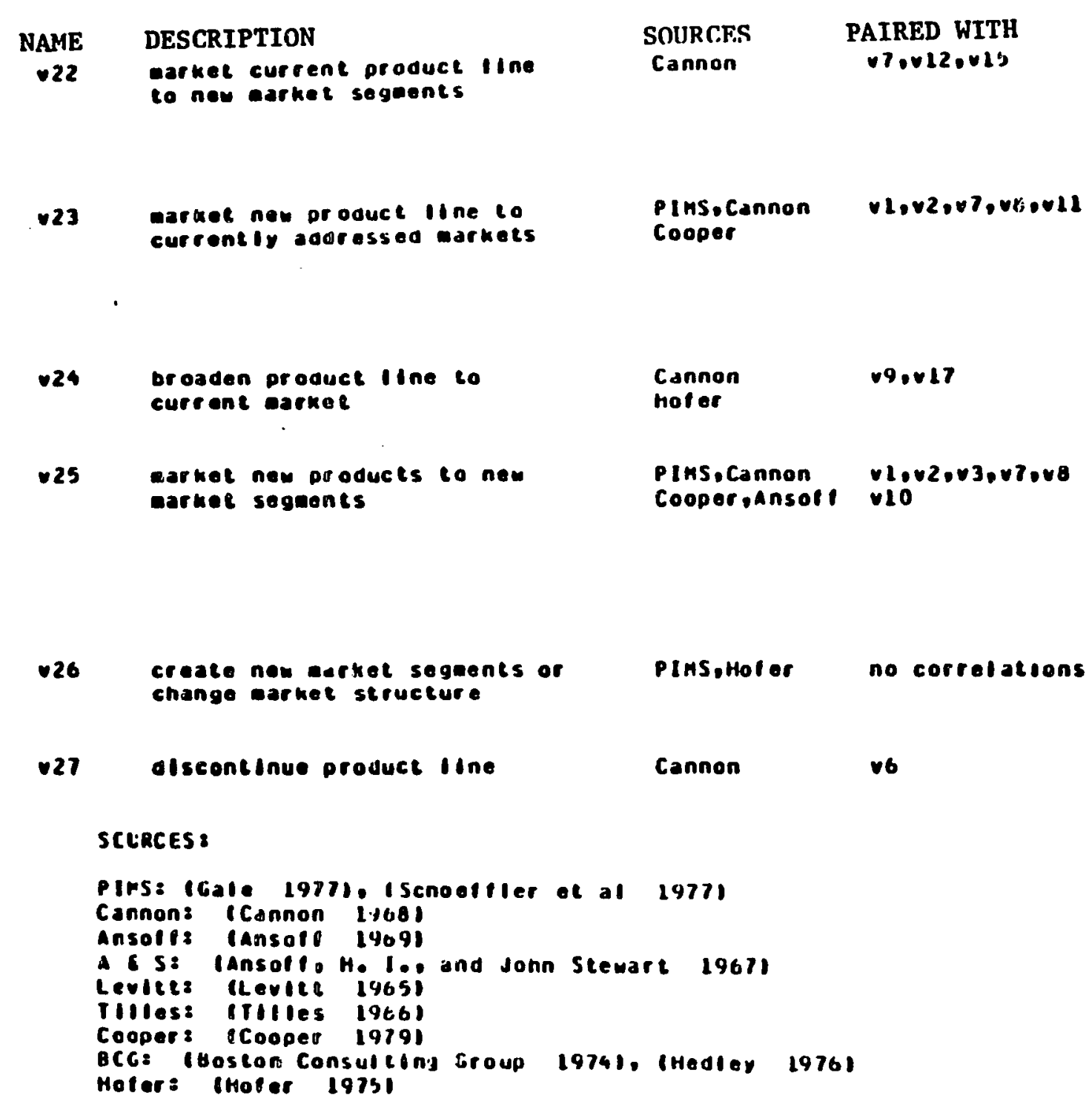

EXAMPLE

- ocus on a succession of atches ae the upper end and more sielectively chan before... spectatide in those

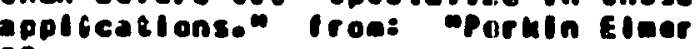
3.

- the new syster is a hatural for HP. a ajor supplier of both aint compaters and desion and develiepaene

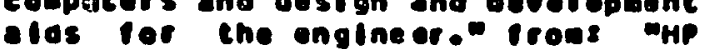
enters 9179.0 .75 .

-... product diversiffeation in a $\bullet \bullet \cdot$ plan cios.

- whe 3220 oe. Is al and ae oens and onc-users in hign perteruance conarelat iransaction appiteatlons. - maches Pormin Estar

arket Perkin Eleer

masn't vigorousty pursuaded trang - Partín Elaer ..... Euceronle Dusiness, 9/79, 0.83.

- ade another dimension te the parket, awakening ene need for .0. preas usiness plan 1207 .

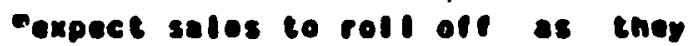
iproduct IInel age iscmolegteallyo proar business plan 107.

arheouomich had been our uajor produce uas abandoned $\ldots$ u have ne other ol ans to address ..e troes bustiness plan 495. 
relate to the fact that business planninis takes place within the operating environment of the organization. The wanagers responsiole for the plan content are the same managers responsible for the current activities of tine business. The historical continuity of the business and the essentially conservative nature of the business planning process mean that in orcer to maintain stability, manayers are tied to proposing planned activities that are the same as or a continuation or current activities. (Quinn 1978) Thus, instead of predicting oreanization actions basei on conditions, one is more likely to be able to predict the conditions planned for and the proposed actions if one knows current activities. Business planning may take place in the wode of searcinine for a problen for which an in-hand solution is valid.

question of utilitye objections to the utility of tris liociel center on the idea that the organizational context in which planning takes place influences plan content. Particular organizations have their own character, culture, or logic.(Sarrazin 1977) General conpanj strengths, weaknesses, policies or history may dictate certain alterrate action solutions or elininate optimal action solutions for particular business conditions. The top managenent goal of integrating a decentralized company increases the likelihood that business strateiy for a particular business will be less than optimal.

Organization structure and character may result in both conflicting objectives and inadequate or conflicting planning data bases. Individuals and suborganizations have often specialized for addressing specific organization problens. (Lawrence and Lorsch 1967) Data essential for planning are often fragnentary or unavailable. 
Organization priorities may be such that collecting these data, if they can be collected, is too expensive. (Leyshorn and Paul 1976)

This argument says that the nodel isn't useful because the major difficulty is in deteruining the conditions and objectives (the strategic assumptions); not in proposing actions. A more useful model would be a model which describes the crystalization of strategic assumptions when knowledge is incomplete and goals are ambiguolis. (Thompson 1964)

\section{Intent of this Study}

The intent of this study was to compare actual content of the business plans produced through the formal planning system at The Corporation with the content predicted by the model shown in Fisure 1 , (p. 6). By further exalination of deviations in actual content fron this model, the utility and valicity of tinis model could be evaluated and/or a wore useful or valid model may be suggested.

\section{DESCRIPTIOH OF THE STUDY FIM!:}

The firm studied in this exploratory effort was the Fast Delta Corporation, a 'Fortune 500' manufacturer of industrial electronics. The Corporation operates in a rapidly changing, complex environnent. Corporation structure is a conplex multidivisional structure vhici includes several foreign subsidiaries and joint ventures, centralized research and sales organizations, and a centralized vertically integrated manufacturing operation. Growth rate during the study period was exponential, in excess of $20 \% /$ year, and reaching almost $\$ 1$ billion by the end of the period. During the study period, Fast Delta 
Corporation product lines and markets were heavily impactsd by the substantial technological innovations and changes characteristic of the electronics market over the last 15 years.

During the study period The Corporation was organized as a multidivisional decentralized company. As Chandiler (1964) reported, a survey of fifty of the largest industrial companies showed that

what way be called the multidivisional type of or anization has become generally used by industrial firms carryine on the nost diverse economic activities. In this type of or enization a Eeneral oficice plans, coorcinates, and appraises the work of a number of operating divisions and allocates to theld the necessary personnel, facilities, funcis, anc other resources. The executives in charge of tirese divisions in turn, have under their command most of the functions necessary for handing one major line of products or set of services over $c_{\text {. wide }}$ geographical area, and each of these executives is responsible For the financial results of his division and for its success in the market place. $(p, 2)$

This multidivisional or decentralized structure vas videly accepted by three industries includins the electrical and electronic industry. Leaders in these industries have relied priwarily on diversification as an expansion stratejy, and as noted by Chandier, the nultidivisional form both allows and encouraces the diversification stratefy. Tije Corporation, like General Electric and Westinghouse, adopted the multidivisional form in order to facilitate diversirication. In the six years since adoption of the multidivisional structure, The Corporation evolved fros a company doninated by a single product line to a corporation consistine of 19 businesses, only two of winich were in the original product line during the period under study.

The Eeneral multidivisional structure (Chandler 1964, 10) is comparable to the multidivisional structure as implenented by The 
Corporation. (See Figure 2, p.15) At The Corporation, the central office includes central manufacturing, central research and development, central sales, and central finance and administration offices arid operations. The operations organization includes four major divisions. Each of these is further subdivided into several marketing-ensineerins organizations or business units and a manufacturing oreanization. Divisions are generally organized by product type. Engineerino and manufacturing concerns within each division are similar. Busiress units are also Eenerally based on sivilar product type althougin soue businesses address a vertical narket with several different product types and others are based on similar distribution channel.

The strategic planning structure at The Corporation, like those ai other large multidivision companies, is based on the business unit. (See Glossary, Appendix A, p. 123). The strategic business unit fort: of organization was initially formelized by General Electric.(Taylor 1976) At G.E., a strateğic business unit consists of a single prociuct line or market. A business strategy is developed for each business unit. The corporation for strategic purposes is assumed to consist of a collection of separate investment opportunities. The managers of each strategic business unit compete witis each other for corporate resources via business plans. Each plan takes on the nature of a "ousiness prospectus."

Because of this decentralized organization structure, top management and middle management roles in strategic business planning have evolved over the last 15 years. Formerly, 'top-management' and 'strategic' planning were synonymous (Steiner 1969), and middle managers 

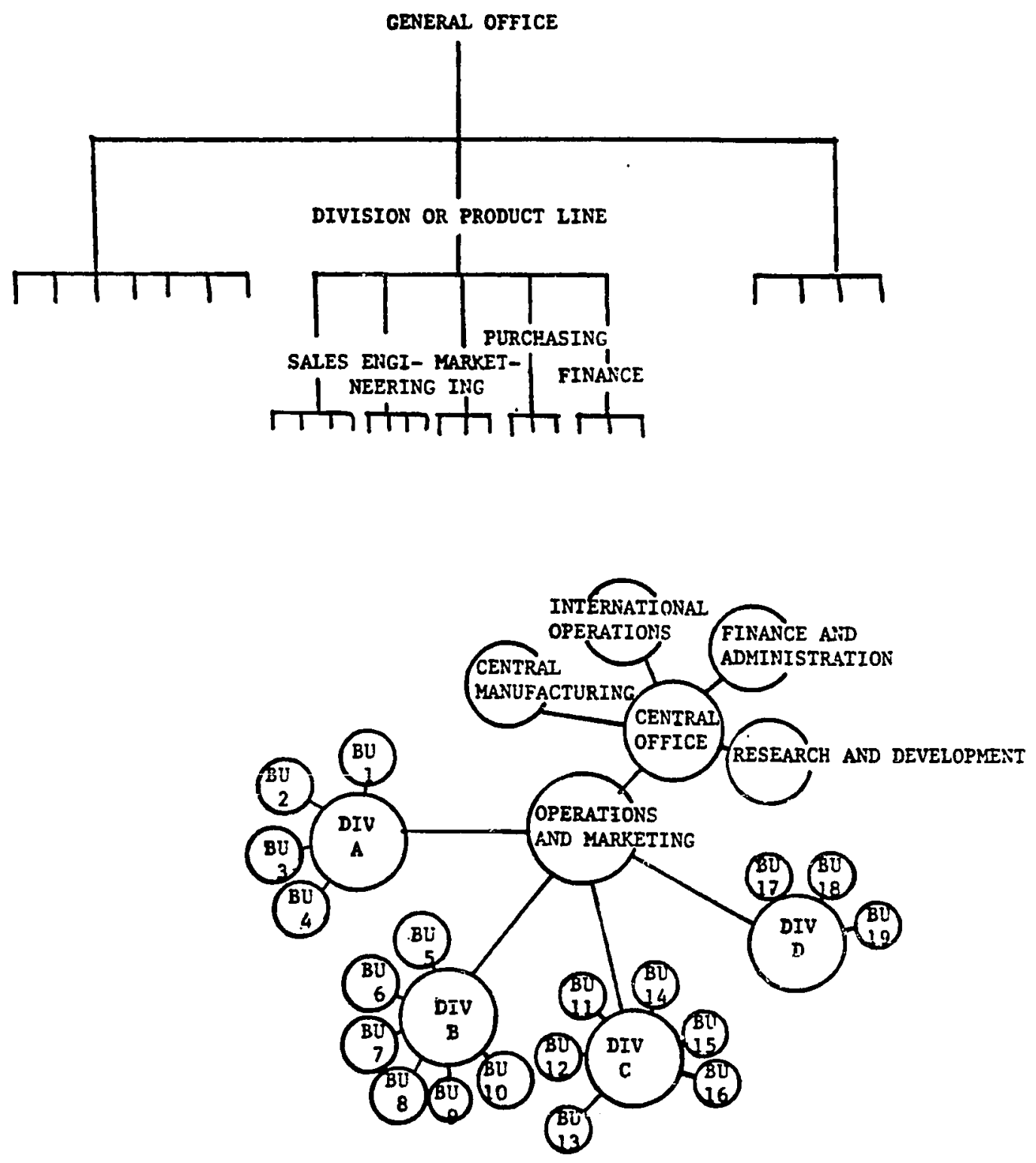

Figure 2. Comparison of General Multidivisional Company Structure (above) with Fast Delta Corporation Structure. General multidivisional structure example is taken from Chandler (1964, p. 10). Both structures 1llustrate the decentralization of operations and specialization of organizations around markets and products rather than around functional structures. 
concerned themselves with operational planning and budgeting. The top management strategic role now rocusses more on the task of "unifyine all. the business lines of a company and pointing then toward an overall goal." (Business Week December 18,1978, 62) In the sinplified strategic portfolio model, the top management task is one of ranaging a portfolio of business investment opportunities, while middle managenent is responsible for the more entrepreneurial task of developing the optimal business strateğy for their sub-organizations.

The framework within whick the business planning systed was established evolved over several years followint the establishment of a multidivision structure. (Technoloty Report, April, 1980) The first planning conference developed statements on corporate vaiues, purpose, and de facto objectives. Two years later a statenent of corporate intent was developed. In the followine year corporate objectives and strategic policies were developed and the first business plans vere written. The Corporation management inforuation systeks allow staff and mana belient at the central office, division, and business unit levels to nonitor operating performance vs. plan and budget. Hanagenent at division level is held accountable for expenses, contribution incone statenent performance, order volurie, inventory levels, and net sales.

\section{DESCRIPTION OF BUSINESS PLANIING AT THE CORPORATIOH}

The business planning process at Fast Delta Corporation, like those at other similar multidivisional corporations, offers three key features:

1) the information flow between corporate and divisional levels, 
2) the annual frequency with which strategic plans are developed and reviewed,

3) the ties to other more operational planning processes particularly budgeting.

These three features are illustrated in Figure 3, (p. 18). A more detailed flow chart of the strategic planning process at The Corporation is shown in Figure 4, (p. 19) which also illustrates these features.

The period covered by this study inclucied trie first siz years after the establishment of a forwal decentralized business plannino systew. Business unit management was annually requireci to subiit a written plan coverine a five year plan horizon in a forrat specified by a corporate planning staff and corporate manafenent. These plans were reviewed by the plannine staff and corporate managenent and in sone cases returned for changes and revisions.

In the first tiro years of the six year period under study, midile managewent was given little formal guidance in terms of perforiance objectives. In one year, planners vere asked to provide both maintenance and srowth-oriented plans.

In the last three years of the study period, the planning process nore closely resembled Figure $3,(p .18)$. Direction becare more "top-down" and corporate management becane more specific about both financial and market performance objectives. In the later years of the study period, The Corporation planning syster also more closely resembled Figure $3(p .18)$, in that the formal business planning process became more tightly coupled with other corporate planning processes. Initially, business planning was regarded prinarily as a managenent. 


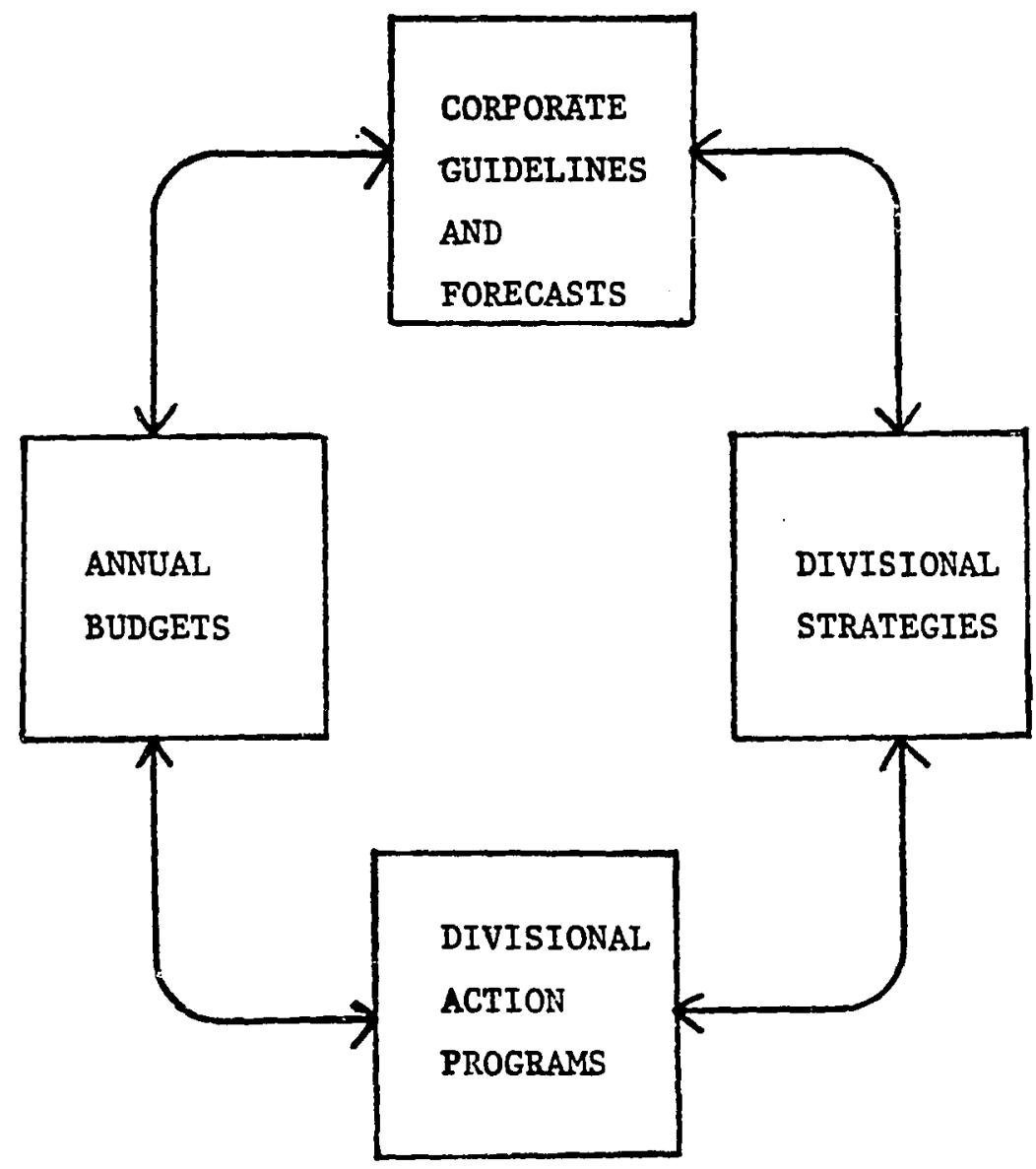

Figure 3. Overview of Strategic Planning Process Illustrating Three Key Features. The three key features are 1) annual cyclic process; 2) connection between business strategy planning and other operational planning processes particularly budgeting; and 3) crosslevel communication between corporate and divisional offices. Diagram from Taylor (1976). 


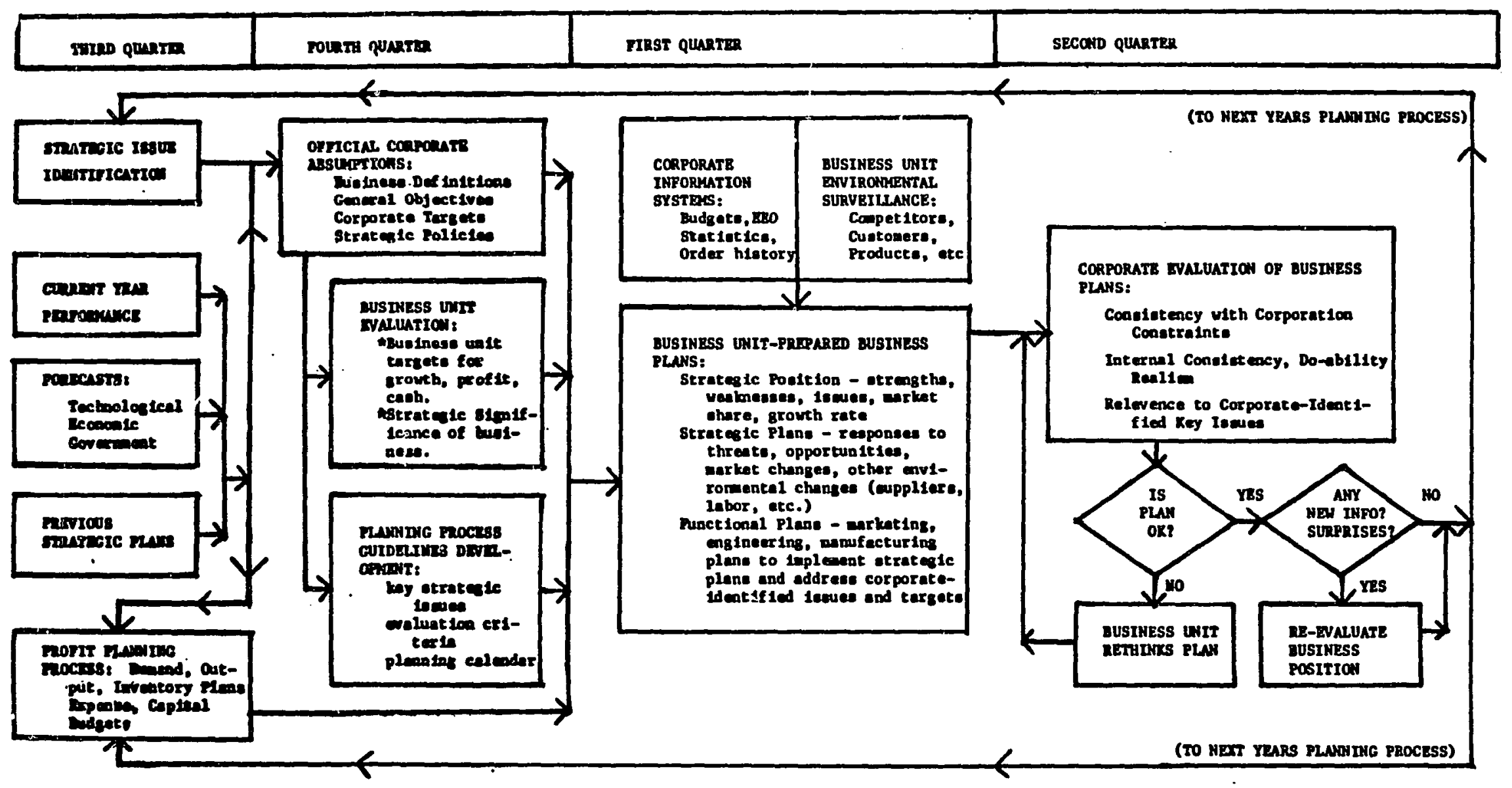

Flgure 4. Overview of The Corporation Strategic Planning Process. This figure 1llustrates the same three key features as the more general Figure 3, (p. 13). The annual cycle begins at the left side of Figure 4 with corporate issue identification and guidelines. Process proceeds toward the right with business unit and division staff input during the first quarter. Corporate staff and officers evaluate business plans, and the results provide the input to the following year profit planning process. 
development exercise and a communication process. In later years, these purposes rewained important, but the two year expense and capital requirements forecasts developed as part of the rive year plan were used in planning expense and capital budgets in the following year.

The Corporation plan content and plan evaluation criteria are similar to those used by other conpanies. Figure 4 (p. 19), which includes an overview of the business unit plan developrent process at The Corporation appears very sinilar to the process shown in Figure 5 (p. 21), which illustrates the Sperry Rand process for developini "romentur plans" or long range plans for existing businesses. (Geririci: 1976)

Althougin business unit nanagement was required to address speciai thenes or areas of corporate concern during sone years and althougin the reportine format for financial performance and objectives varied from year to year, plans generally were required to cover the saile topics. The following list of required sections in a Corporate business plan from the Corporate Strateric Plannine lánual (1977) appears very sililar to the list of essential elements of corporate planning provicied by Taylor (1976): business definition includine strengths, wealnesses, synergy with coupany, market and custoner analysis, competitor analysis, econowic analysis, strategic targets with respect to Eroith, profitability, market share, and cash flow, strategy and action plans, and financial statements.

\section{LIMITATIONS OF THIS STUDY}

This study was characterized by several linitations: 


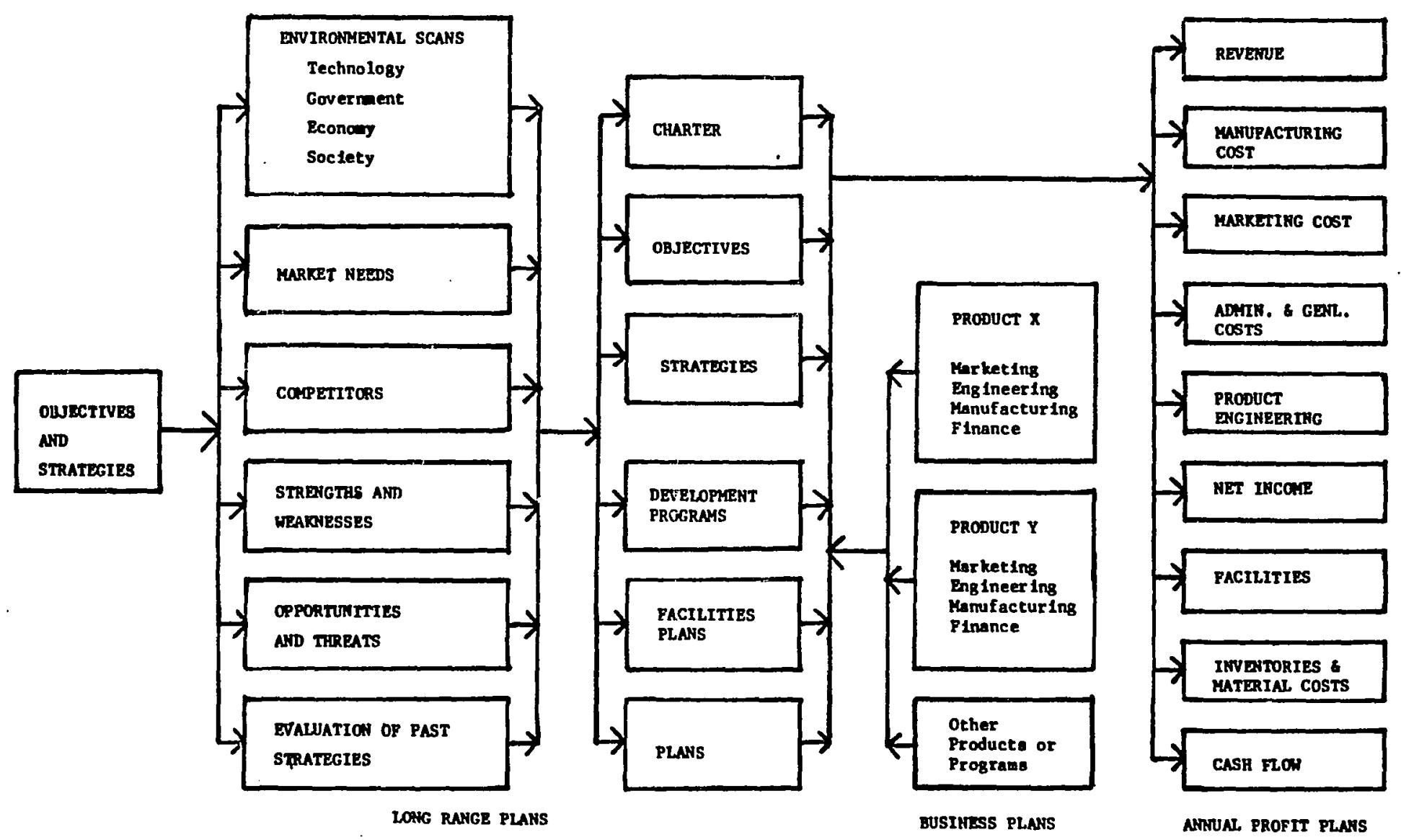

Figure 5. Overview of the Strategic Planning Process for "Momentum Plans". This diagram (Gedrich 1976) illustrates the process used by Sperry Rand for developing momentum plans, or strategic business plans for existing businesses. Figure 5 focusses on the business unit role in translating internal operating assumptions (objectives, charter) and external operating assumptions (market, competitors)

into action strategles and resource requirements. 
1) The study was confined to the exanination of a single company. The strategic planning process and structure implemented by this conpany were similar to those implemented by other companies as described in the literature referenced above. However, the results, conclusions and recomindations from this study can only be applied with caution to other conpanies. Since this effort was an exploratory study ained eventually at developing a better description of business plan content and improved techniques for evaluating plan content, the results of tinis single-company study could be tested further in other conpanies.

2) During the research project, the researciner was employed as the business unit planning manager for one of the Fast Delta Corporation business units. In this position, the researcher was responsible for coordinatino strategic and operational planning processes in that business unit. The wajor advantages of the researcher's euplojee status were increased access to highly confidential business plan content and increased access to middle manafement ideas on appropriate planing; logic. Enployee status may, however, have introduced bias in the judGuent required to code data on plan content and plannine lor̈ic. Every effort was made to reduce this bias through reducine the judgrent required to code data. The coding process was nearly mechanical and no analysis was perforned until coding was complete so that preliminary results did not bias further coding. These efforts to reduce cocine bias are discussed further in Chapter III (p. 40 ).

Bias which may have been introduced by the researcher's personal acquaintance with interviewees or by personal commitment to organization direction was reduced since the researcher was a new employee of The 
Corporation during the study period. As a new enployee, the researcher was unacquainted with most of the management interviewees and also unacquainted with the particular problems and characteristics of most of the businesses and sub-organizations with which intervievees were affiliated.

Researcher bias in this study was a real danger to the validity of these results and is a problem which is likely to occur in any further research. Because of the confidential nature of much of the data analyzed in this study, further testing of the models suggested here or implenentation of new plan evaluation methods will most probably be done by employees with the company under study.

\section{SUIIAAY}

Study objectives were identified as those of testing an expected model of plan content, developing a modified model of plan content, and developins a modified method for evaluating plan content based on this modified content model. Significance and unique aspects of this study were discussed. A matrix of expected plan content was introduced as the yardstick against which plan content would be neasured. Reasons why plan content way vary from this model were discussed. The study firi: was identified as a high technolozy, multidivisional company. The company's organization structure and strategic planning process were described with the intent to show that this company's planning structure and process are generaliy similar to those described in the literature as characteristic of other large firms. The researcher's position as an employee of the study company was discussed as both an advantage (access 
to highly confidential information) and a disadvantage (source of bias). Efforts to reduce this bias were discussed. 
CHAPTER II

REVIEW OF THE LITERATURE

The purpose of this revieu is to examine the nodel of expected strategic plan content developed for this study, the objections to the assumptions on which this model is based, and an indirect method for studying these objections.

EXPECTED CONTENT OF FORIAL PLANS

Corporate Stratesy and Stratesic Plan Content

Tilles (1963) writing on the benefits and purposes of formal strategic plannine, stated that a major purpose of the formal process is to make strategy explicit. Even those authors who complain of a gap between the content of formal strategic plans and corporate reality agree that the content of formal strategic plans should reflect a 'slice-in-time' image of managenent strategic perspective.(Quinn 1977,Quinn 1978, Koontz 1976, Hobbes and Heany 1977)

Formal plan content should thus represent organization strategy. Contingency theory, based on an open systems model of the organization, says that organization strategy can be predicted. This was the function of the model of expected plan content introduced in Chapter $I$. The origins of the model of expected plan content were in the open systems models of organizations developed by Thompson (1967), Lawrence and Lorsch (1967). The rationale for this model can be summarized as 
follows: Organizations aim at an adaptive match of environment and organization characteristics. For a set of organization and environment conditions there is an action set or strategy which might best enhance the organization's survival objective.

In the following discussion of normative models of strategy, the authors referenced all used financial measures for organization success or survival. The strategies suggested were successful with respect to some objective financial measure.

\section{Nomative liodels of Strategic Plan Content}

Hofer and Rumelt developed contingency theory specifically for business strategy development. Hofer (1975) sumnarized researci supporting a contingency theory of business strategy. Rumelt (1979) covers similar ground in reviewing what he called frame-based evaluation criteria for business strategy. The message from both authors was:

1) Successful stratefies are based on a successful natci between the organization and environment context.

2) Once the context is known, the success of alternate approaches can be predicted.

3) Useful evaluation criteria are those which checl the proposed strategy against its context.

Hore specific evaluation criteria are based on guidelines for effective strategy developed by the Strategic Planning Institute's PIis (Profit Impact of Market Stratesy) study effort. (Schoeffler 1974, Schoeffler 1977) The PIMS perspective and research provide the primary support for the expected content model shown in Figure 1 (p. 6 ). Chief finding of the PIMS effort was that "business situations generally 
behave in a regular and predictable manner." This means:

that we can estimate the approximate results (within 3-5 points of ROI) of most businesses (about 90\%) over a moderately long period ( $3-5$ years) on the basis of observable characteristics of the market and of the strategies employed by the business and its competitors. . . Business situations can be understood by an empirical scientific approach, and therefore the process of formulating business stratezy is becoming an applied science.(Schoeffler 1977, p.1)

PIIIS research identified a list of nine major influences on profitability: investment intensity, productivity, market position, growth of the served market, quality of the products and/or services offered, innovation, differentiation, vertical integration, cost push, and current strategic effort. Although the PIISS staff adritted that the "operation of the nine major strategic influences is complex", they also showed that "the laws of the marketplace deternine adout $80 \%$ of the observed variance in operating results across different businesses." (Schoeffler 1977, 2)

The relative specificity of the PIls marketplace laws allow tine relation between conditions and strategic actions to be brol:en down into a series of expected associations between condition and action sets. Other sources for strategic planning guidelines included tine Boston Consulting Group (Boston Consulting Grodp 1974, Hedley 1976) research on narket share, relative competitive position, and ezperience curve; enpirical studies of specific product-market problems such as Cooper's study of new product introductions (1979); and surveys of business experience such as J.T. Cannon's Business Strategy and Policy (1968). The specificity of these marketplace laws suggested that the business conditions and strategic action should be explicitly associated 
within the context of the formal plan.

Because these marketplace laws apply to all businesses one would expect to find similar pairs of conditions and actions in all effective business plans. Table I (p. 7) lists key variables describing comon business conditions and actions and the expected bivariate relations between these conditions and actions based on the above business studies. This set of bivariate reiations provided a miniwur set of logically related pairs of variables describins plan content. Fast Delta Corporation plans were expected to contain these pairs of variables if this model was characteristic of the Corporation's strategic planning logic. The matrix model shown in Figure 1 (F. 6) sumnarizes these relations.

Implications of Expected Plan Content lodel for Plannins Process

The contingency theory of organization behavior listed above implied a two step planning process: first concitions must be specified; and second, strategy and action plans must be developed. This process is shown in a simple block diagram in Figure 6, (p. 33 ).

This process is also inplied by the order in which information was presented in the business unit plans as required by the corporate Strategic Planning Manual. (1977) This process was explicit in the description of this and other formal planning processes discussed in Chapter I as well as explicit in the strategic planning guides developed by Steiner (1969) and Ansoff (1965). 
OBJECTIOHS TO THE EXPECTED COITENT HODEL

Objections to the expected content model were based on three argunents:

1) the expected content nodel was too simple.

2) the process model inplied by the expected content wodel isn't valid.

3) the expected plan content model isn't useful.

Expected Content liodel Simplicity

Characterizinê business strateđy as a list of relatively simple business context and action variables was a difficult task. Tho problews appeared inuediately:

1) the difficulty of choosing a list of characteristics which were both simple and complete, and

2) the linitations of viewini only bivariate relations betreen variables.

Hiller (1979) pointed up that bivarate-based (ie prociuct-bonent correlations) contingency theory research has resulted in contracictory findings. He concluded that bivariate relations are insufficient to capture the complexity of organizations' environments and suggests that more useful results could be attained by studying more closely specified contexts.

Hofer (1975) addressed Miller's concerns in his article when he cho4seses a relatively complex, synthetic concept such as product life cycle phase as the key deternining factor in business strategy. His own normative business strategy propositions listed six context descriptors 
in addition to life cycle phase before prescribing actions. As he pointed out, however, extending this approach would mean countless thousands of propositions for each combination of signiricarst context descriptors.

The nociel, based on bivariate relations shown in Ficure 1 ( $p$. 6), and Table I (p. 7), allowed a simple comparizon of actual plans witi the results of descriptive business researcin. Hovever, the aisence of appropriate matches between context and proposed actions in Corporation plans may sirply have indicated as ililler (1979) suscested that stratery is too complicated to capture as a coubination of bivariate relations. For this reason further analysis of deviations in actual plans from the plan model relied on techniques which icentify nore conplicated relationships among variables.

\section{Process liodel Validity}

The argument that the inplied process nodel wasn't valid centered on an alternative view of the stratesy setting process. In this vieu, introduced in Chapter I (p. 4), strategy is fixed and the organization searches for an environment for which a particular specific strate successful. This is exactly the opposite of the expected model which says that strategy is based on an analysis of the environuent. Sainal (1976) developed this nodel of organization adaption in Eeneral systens terns. He concluded that "conditions $=f(s t r a t e g y$ proposed)" is a viable alternative model of organization planning. Business strategy literature offers several examples of tinis approach. The most comson examples dealt with the task of defining targeted market segments. In "Strategies for Low lfarket Share Businesses," Hamiermesh et al (1970) 
argued that small share businesses needn't always try to Erow. An alternative strategy is changing the environment by resegnenting the market. Redefining the environment means that strategies which coulcin't succeed in the larger environment way succeed in a more restricted environment. The key role that market share estinates play in business strategy literature makes market redefinition and resegnentation particularly important when the oreanization is constrained by current conditions that it is unable or unvilling to change.

Soti tine literature anci inforial coments from manacers suiciest that tinis approach is videiy used. They agreed trat strong considerations in strategy setting are current position, current mowentur, and current activities of the organization. (Drucker 1973, 123)

Cyert and liarch's behavioral theory of the organization $(1963,34)$ and Quinn's concept of lowical increnentalisi (197i) stresseci the importance of learuine from current activities and preciritatins events. The benefits of the increriental approach are that it "inproves tire information content and the process aspect" of decision-making by allowing participants to test assumptions and build support and confort amorie others.

According to Fast Delta Corporation nanagers, the major step in the annual strategic plaming process was an assesswent of current activities and a testing of these activities against a personal wodel based on experience, expectations, and analysis of data. The strategy developnent process was based on the sul of experience which one general manager called "gut feel". These informal coments suggested that one of 
the best sources for explicit assumptions stated in plans is the experience generated by current activities.

The above literature and inforwal cominents sussested the nodiried block diagrar. of the planning process shown in Figure 7, (p. 33 ).

Both Figure 6 (p. 33) and Figure 7 (p. 33) depict plannine as a unidirectional process. This view way be too sinple. liost authors on the normative planning process emphasize the importance of iteration, or checkinis results against analysis of conditions. Heither the nori:ative plannins process wodel nor the model shown in Ficure 7 (F. 33) should be more dominant. The addition of "iteration" to the initial uni-directional nodel is the essence of the concept of "adaptive planning" (liintzberg 1973). However, in practical planning applications, the iterative process nay not be impleuented. Iniormal counents from Fast Delta Corporation managers indicated that under time, resource, and process constraints, they siuplified tre forlial process to a uni-directional non-iterative process. It was not clear which process nodel was more descriptive of plannine at The Corporation and what impact this night have on plan content.

\section{lídel Utility}

Guth (1976) sumuarized the work of Ansoff (1965), Steiner (1969), and others when he identified the basic intellectual tasks of strateagy formulation as:

1) the assessment of environmental conditions and trends and identification of opportunity and threat 2) the determination of comparative strengths and weaknesses of the organization for competing in particular product, market areas 3) the iuentification of the objectives, coals, and values to be served by the organization 4) the identification of the requirenents of 
FORMAL PLAN CONTEXT

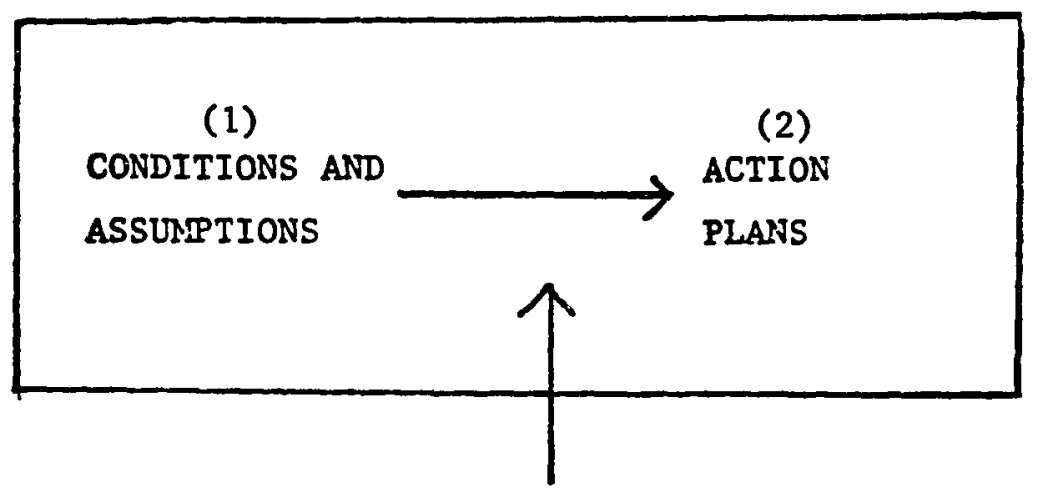

MARKETPLACE LAWS

Figure 6 . Model of Normative Planning Process. This simplified block diagram illustrates the normative planning process as irplied by the corporate Strategic Planning lanual (1977). First, business conditions are specified. Second, based on these conditions and on marketplace laws, actions are proposed. This process should produce results consistent with those predicted by the expected content model.

FORMAL PLAN CONTEXT

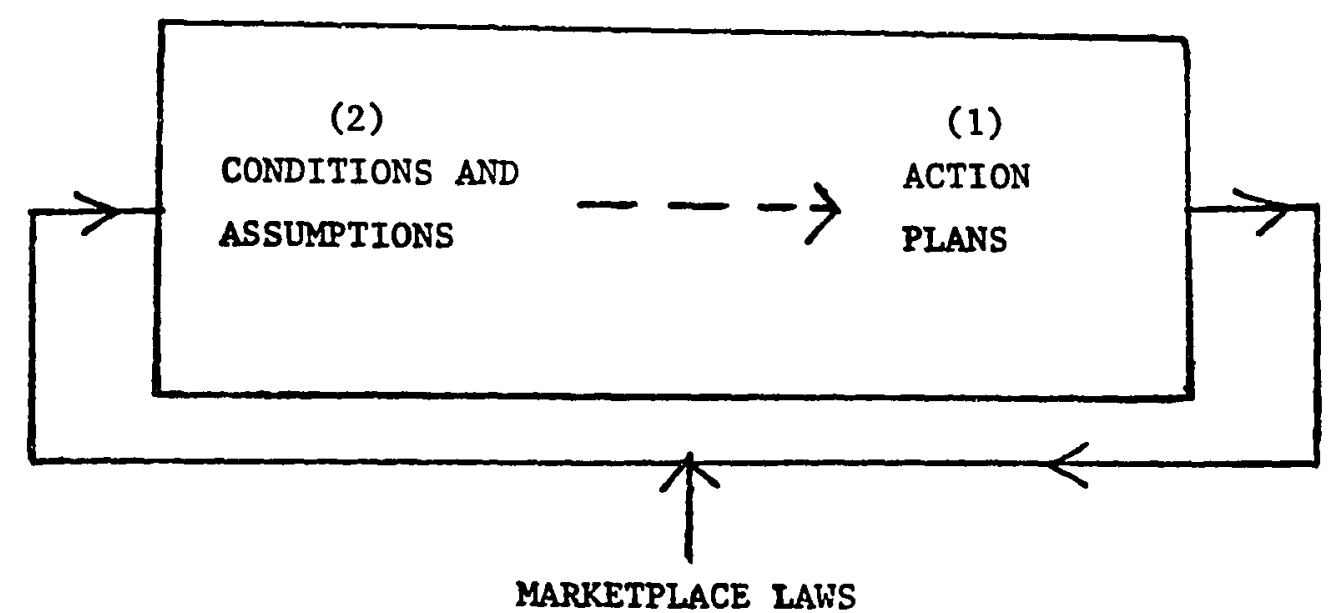

Figure 7. Model of Modified Planning Process. This nodel is based on the suggestion that current activities and strategies play a major role in strategy forwulation. First, action plans or strategies are specified. Second, assumptions about business conditions which are consistent with these current activities are developed. Because the format of the formal plan was fixed as required by the Corporate Strategic Plannine llanual (1977), the format of the plan continues to imply that the process used was that shown in Figure 6. 
a chosen strategy on the particular management structure in order to implement that strategy effectively and efficiently.

The expected content model is what Thompson called an "efficient" model (1967, 86) and what Allison (1971) called a "rational actor" model. By efficient, Thompson meant that plan content can be evaluated in terms of "relative perfection."(1967,.86) That 1s, "was the effect produced for least cost?n or "was the greatest result produced for a given amount of resources?" The rational actor model assumes not only efficiency evaluation criteria but a structured problem solving process. In the rationai actor model, the tasks described by Guth are achieved easily because of two key simplifing assumptions:

1) The planner or decision-maker is rational. That is, the filter between "reality" and the development of explicit assumptions is transparent and the strategy is based on complete information about the real world.

2) The plans and decisions are made by a unitary decision-maker. "Standards of desirability" or values are crystalized and unambiguous. (Thompson 1967)

Under these simplifying assumptions or premises, Guth's condition specification processes are trivial tasks of collecting data.

The argument that this model is not useful centers on the work by Allison, Thompson, Guth, Cyert and March and others who suggested that these premises are too simple. Knowledge is never complete nor are values crystalized.

Incomplete Rnowledge. The difficulties of planning with Incomplete knowledge are well documented. Leyshon (1976) and Paul, Donavan, and Taylor (1967) identified the practical problems in 
gathering information on current conditions, integrating this as a set of assumptions in a timely way and forecasting in a changing world. The decentralized business unit-based planming oystem partially addressed these difficulties. This is because this structure allowed the individuals who are experts in a particular business to develop the pians. The technisal tools of analysis and forecasting are more appropriate to the business planning task of developing an optimum business plan than io the more difficult corporate planning task of trying to balance and Integrate the investment portfolio of corporate businesses. (Business Week December 18,1978, 62)

Despite the business unit structure which involves more "experts" in plan development, differences in individuals' knowledge bases can contribute even at the business unit level to different "standards of desirability." Lawrence and Lorsch (1967) have studied what might be called centrifugal forces operating on organizations against unity and integration. They identified a chief difficulty in integrating different functional areas. They concluded that differences among functional groups are basic (differences in goal orientation, time orientation, and interpersonal orientation). These differences are unresolvable since they are adaptive to solving the functional problems which must be addressed if the organization is to survive. The impact of differences in functional perspective on strategic planning perspectives is unclear since functional problems are typically regarded as more operational and less strategic.

Ambiguous and Conflicting Values and objectives. While the business unit structure partially addresses the incomplete knowledge 
problen, it introduces new complexities into the problen of planning with ambiguous objectives and values. With more individuals and rore suborganizations involved, the task of resolving differences and integrating conflicting objectives is more difficult.

The Business lieek report on the "lvew Planning" (Decenber 18,1978) reinforced this perception of the expected content rodel as inadequate. Even though the new planning way allow the developient of wore "efficient" business plans, corporate planners nust still intêrate these plans in order to develop a corporate stratej. The logic behind a particular business plan which can be easily integrated with corporate level strategy is not necessarily the sane as "efficient" löic. Efficient locic may dictate agfressive product developient effort and heavy resource use for a business which is not himl on the corporate list of business priorities. Without the resources available for product development the business must opt for another less optival strategJ.

Literature offered two alternate views of the inpact of conflicting objectives on strategy planning. Both views, however, agreed that the simple efficient model is not useful in predictinis the outcoue of the stratesic planning process.

1) One view was that conflicting objectives among suborganizations and individuals mean that an organization does not operate as an integrated whole. Cyert and March (1963, 36) concluded that the organization may appear integrated even while suborganizations are aineci at achieving conflicting goals. This is because there is enough organization "slack" so that suborganizations cail pull in different 
directions without pulling the organization apart. Allison (1971) summarized both this model and an alternate "bureaucratic politics" model which assumes conflicting objectives among individuals. Both models described the dynamics behind what is included in a strategic or any other plan and how the plan is used and evaluated by its readers. Neither model depended on the quality or efficiency of the plan content because both assumed that other reasons outside the formal plan logic better explain plan content and evaluation.

2) A second view supported by Emshoff and Mitroff (1979, 1978), Vancil (1976), and Sarrazin (1977-78) was that organization dynamics can be addressed and controlled so that an integrated strategy can be developed and implemented. These authors offered three complementary suggestions for improving the process by which objectives and the iogic relating conditions with appropriate actions are developed.

a) Mitroff and Emshoff developed a formal strategic assumption analysis based on a Hegelian debate process which assumes conflict and bias among participants.

b) Vancil developed a conceptual model of integrated organization strategy which involves management at all levels through "an intricate web of personal statements."

c) Sarrazin suggested an informal but deliberate apprenticeship program for managers in the corporate strategic logic.

The first view suggested that formal plans are unlikely to reflect either the efficient logic of the expected content model or any other logical pattern. The second view suggested that if the corporation has attempted to integrate strategy the business plans may well demonstrate 
a consistent approach even if it is not the efficient logic of the expected content model, In either case, the efficient model is not useful in predicting plan content because other processes dominate the nornative planning process.

\section{TECHNIQUES FOR STUDYING ASSUMPTION SETS}

While the task of studying assumptions-strategy match was initially a straightforward comparison of actual against model, the task of explaining deviations from the model was more complicated. Wilcox (1972) pointed this out in his study of decision assumptions. He viewed assumptions as a "network of causal relationships" linking goals and the perceived situation to the consequences of decision. In a non-optimizing decision process, such as the decision of what strategies to propose in a formal plan, he identified two ways to determine the relevant assumption set. The first was via direct modeling of the decision net. This required direct observation of what Newall, Shaw and Simon (1958) called the problem-solving protocols and has been used extensively in management studies.(Cyert et al 1956, Mintzberg et al 1976) Clarkson (1962), in his effort to predict trust officer investment decisions, used this approach very successfully.

The second way of determining the assumption set was the indirect method used in public opinion pclling, market research, and cognitively orlented psychology. Participants made a large number of independent choices and these data were analyzed via factor analysis or multi-dimensional scaling to determine the underlying attributes or dimensions of the positive cholce objects. Wilcox' indirect approach was 
similar to the factor analysis and sinilarity coefficient approaches used here to search for complex plan logic.

\section{SUITIARY}

This chapter reviewed the baciscround literature relevant to tire problems of describing and evaluating stratesic business plan content. Nomative plan content models sucgested that plan content should convey a logical and consistent association between the assuaptions about tret organization's environment and planned or proposed strategies and actions to address these assumptions. Implied in this nodel of plan logic was a two step process of identifying these assumptions and proposing stratejies based on these. This chapter also included a review of business research on the consequences of specific assumptions for organization strategies. Selected results of this researcin vere sumuarized as tire expected plan content nodel used in this stlidy. Literature suggesting that this model vas not adequate was also reviewed. Various authors have areued that bivariate-based models are too simple for describine a complex subject such as strategy settine; that the inplied process model is neither used nor is it the only appropriate plannine process; and, that efforts to nodel the stratecy settins process and predict strateric content must focus on strategic assurption development, not stratery selection. Two alternate tecinniques were reviewed for studying assunption sets. This study relies on indirect rather than direct nethods for identifying underlying strategic logic. 


\section{CHAPTER III}

STUDY METHOD

This chapter includes an overview and description of the rethods used to gather and analyze data about the strategic planning logic used at Fast Delta Corporation. The two primary data sources were the actual content of The Corporation business plans and the questionnaires on strategic planning completed by Fast Delta Corporation managers. The rationale for the data sources and statistical tests chosen is presented in the noverview of liethod" (p.40). A flow chart sumarizing the study procedure is shown in Figure $8(\mathrm{p} .41)$. The remainder of the chapter provides a more detailed description of each data collection and analysis step.

OVERVIEH OF IETHOD

The preliminary technique used to evaluate the Fast Delta Corporation business planning content was a goodness of fit test of actual Corporation plan content against the expected content model. The model, shown as a matrix in Figure 1 (p. 6), associates certain actions with certain assumptions in a strategic plan. If a condition assunption is present, certain action plans should also be present. Each business unit plan was checked for the presence of the condition and action pairs shown in Figure 1 (p. 6). The reasons behind the results of this comparison between expected and actual plan content ray 


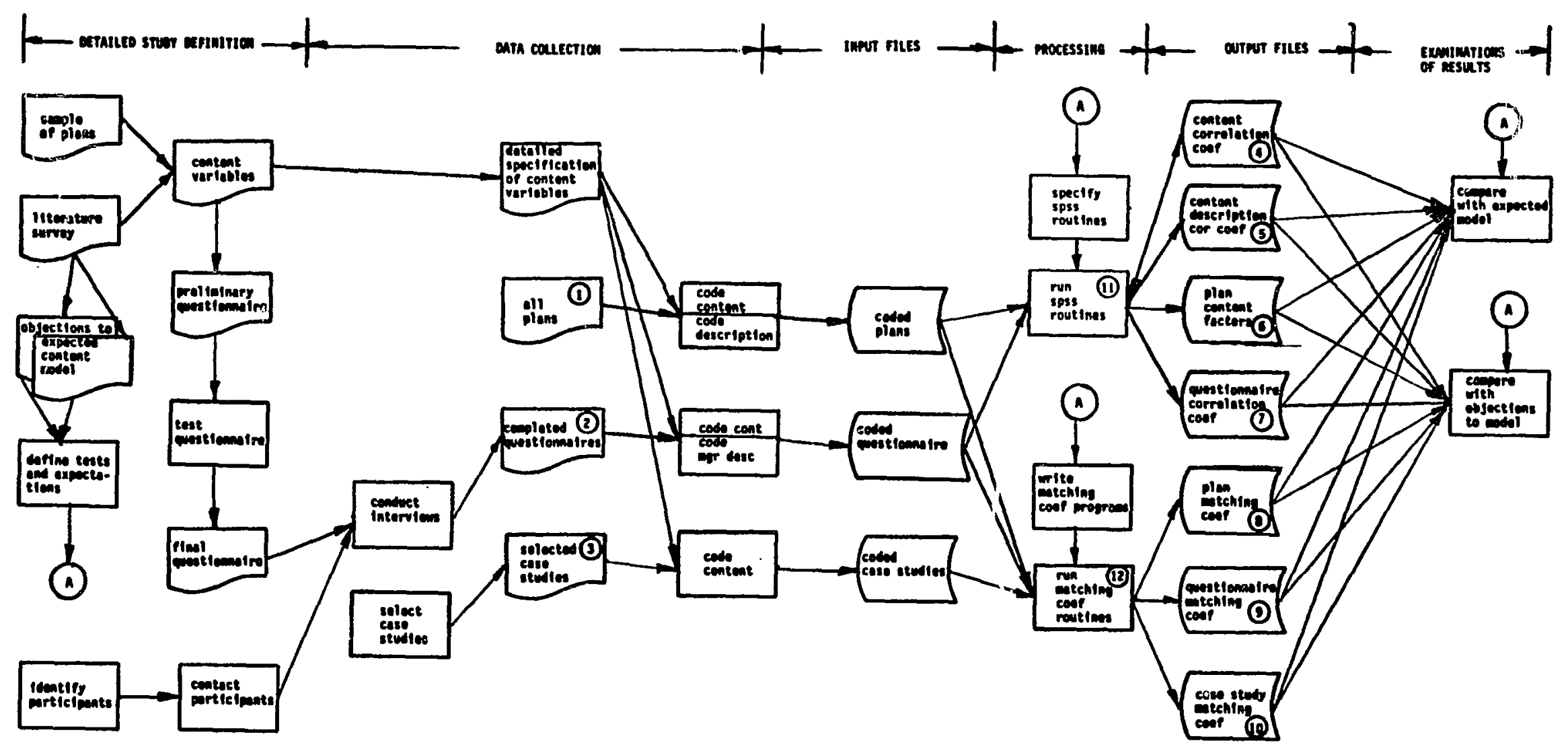

Figure 8. Flow Chart Summarizing Study Method. This flow chart describes the functional steps in this study process. Major steps were study definition, data collection, input file development, data analysis, output file development, and examination of results. The two major data sources were Fast Delta Corporation plans (1) and managers" completed questionnaires (2). A third data source was business strategy case studies (3). Output files containing the results of statistical routines are shown as (4) - (10). The two sources for statistical routines were the SPSS package (11) (Nie et a1 1974) and BASIC routines shown in Appendix C (. ). 
be identified with further analysis. This further analysis, based on objections to the expected content model discussed in Chapter II ( $p_{0}, 29$ ) may suggest both a modified model and content evaluation methods based on this modified model.

Description of this process is discussed in "iodel Comparison" (p. 45) and the results are discussed in Chapter IV, "Goodness of Fit Test" (p. 65).

Objections to the Expected Content Model Based on its Simplicity

Because strategy may be wore conplicated than simply paired conditions and action plans, two other tests for consistent association of conditions with actions were developed:

1) The first was a test of sinilarity anone strategic plans listing the same condition of business. Even if strategy were more complex than paired association between a condition and an action, plans which agreed on the presence of a condition should agree core on proposed actions than plans which did not agree on the presence of this same condition. Development of this sirilarity weasure is discussed in the second section of Chapter III, "Corporate Consistency" (D. 49). The results are discussed in the second section of Chapter IV (p.68).

2) The second was a factor analysis test. Factor analysis of plan content was used to explore for more complex associations anong variables describing plan content. If the expected content model is correct, factors identified should consist of the paired associations among variables as shown in Table I (p. 7). This approach is discussed in "Factor Analysis", (p.52). The results are discussed in the third section of Chapter IV (p.71). 
The discussion in Chapter II suggested several reasons why these expected pairs of condition and action variables may not be found. These included constraints imposed by the operating context of plannine, and constraints imposed by the organizational context. The fourth and fifth sections of Chapter III and Chapter IV exarine the influence of operating context. The sixth and seventh sections of Chapter III and Chapter IV examine the influence on plan content of organizational constraints.

Objections to the Expected Content lodel based on Operating Context

Two approaches were used to study the influence of operating context or current activities on strategic plan content:

1) Inforwation about the plans other than content was collected. This information included the year the plan was written and recent performance history and performance forecasts for the strategic business unit. Content variables were checked for significant association with these non-content descriptors.

2) Corporation managers were asked to participate in an experinent. A two part questionnaire was distributed to manafers who had participated in the formal business planning process the previous year. In part $A$ of the questionnaire managers were asked to develop action plans when a set of condition assumptions was provided. In part $B$, managers were asked to develop an assumption set when an action plan was provided. Questionnaire responses were coded and analyzed using the sane procedures as those used for analyzing plans. One would expect the results from part A to match the expected results predicted by the expected content model. If the results fron part $B$ were more similar to 
the results of the fortal plan content analysis, one would expect that current activities played a sicnificant role in deternining forwal strategic plan content. The fourth section of Clapter III, "Non-Content Descriptors" (p.53) discusses the wethod for gatierine data on the non-content characteristies of plans. The result of this analysis is discussed in the fourth section of Chapter IV, (p.75). The developnent of the planning exercise and questionnaire, procedure, and analysis is discussed in the fifth section of Chapter III, "Plannine Ezercise", (p. 55) and the results are discussed in "Planning Exercise", Crapter IV, (p. 79).

Objections to the Expected Content lodel Dased on Orsanizational Conteit If organizational fiators afiect plan content, there sholild be more sinilarity in stratejic content anong Corporation plans tran anon: the strategic plans of businesses from different companies. Case studies in strateijic plannine were substituted $\vec{i}$ or actual stratejic plans since data from plans of different conpanies would be difficult to collect. The sinilarity measure discussed above was applied to data or the content of these case studies and the results were colpared with similarity coefficients fros Corporation fornal plans. This process is described in "Relative Corporate Consistency", Chapter III, (p.59), and the results are discussed in the sixth section of Chapter IV, (p.82).

Discussion in Chapter II surgested that if orianizational constraints afrect strategic planning logic, individuals with longer lenisth of service and higher organizational position should agree with each other more in strateric perspective. On the other hand if functional trainin: determined strateric perspective, contert variables 
selected in the planning experiment should be closely associated with professional background of planners. Agreement should be higher within similar professional groups than between these groups.

Method for gathering and analyzing data on the individual characteristics of managers who participated in the planning experiment, for comparing individual planning experiment response with professional characteristics and for developing agreement measures within similar groups is discussed in the last section of Chapter III (p.61). Results are discussed in the last section of Chapter IV (p.87).

MODEL COMPARISON: EXPECTED CONTENT VS ACTUAL STRATEGIC PLAN CONTENT

Steps in comparing the Fast Delta Corporation business plan content with the expected content model included:

1) the development of an expected content model. This included the selection and definition of the variables shown in Table I (p. 7) as the expected content model and the identification of expected relationships between these content variables as shown in Figure 1 (p. 6).

2) coding business unit plans for the presence of these variables

3) identification of significant joint frequencies of condition and action variables

4) comparison of significant joint frequencies found in Corporation strategic business plans with expected pairs of conditions and actions suggested by the expected content model.

Variable Selection

The list of conditions and action descriptors suggested in the 
expected content model is shown in Table I. (p. 7) Criteria for the variables selected to describe plan content were:

1) Variable was suggested as important or relevant by one or trore references from business literature review above.

2) Variable frequently appeared in a preliminary study of seven business plans from three business units within Fast Delta Corporation. In this preliminary study, key topics, issues, areas of concern, and proposed actions were listed and organized under such categories as market position, market characteristics, objectives, business strengths, actions impacting financial position, marketing actions, and engineering actions.

3) Variable contributed to relative "completeness" in describing business strategy. While it was clearly impossible to describe all possible business assuriptions and action plans using a combination of statements, this list was selected as a best effort to cover these alternatives as completely as possible.

4) Variable was easy to detect as "present". Because only assumptions and actions which could be coded as definitely present in the document were included, only very specific statenents of conditions, objectives, and strategies were chosen. This proved particularly limiting in the selection of strategies (see v18-v27). Strategies were usually stated in either a very general or global way or else in a way unique to the particular business. For this reason, what frequentiy appeared as a "strategy package" was described as a combination of fairly specific action plans which could be coded as "present" or proposed in the plan. 
This criterion was especially important in order to address the potential effects of researcher bias in coding business plan content and in order to assure that the experiment could be duplicated with comparable results in other firms.

Seventeen variables describing conditions were selected (v1-v17). Ten variables describing strategies were selected (v18-v27).

\section{Variable Coding}

One-hundred-nineteen formal business plans were examined and coded for the presence of the variables described in Table I (p. 7). These plans represented $100 \%$ of the formal plans produced through the formal planning process over a six-year period. These plans ranged from three to almost 100 pages in length but generally followed the format described in Chapter I (p.20). Each plan described a single business, as that business was conceived in the plan year. Durinf the study period The Corporation was organized into an average of 20 businesses but the specific businesses and the number of businesses varied from year to year. In few cases was it possible to trace loneitudinally a business during the entire six years.

A variable was coded as present only if an explicit statement matchine the variable description appeared in the document. Appendix B (p.125) offers an example of the coding process. Included in Appendix $B$ is the managenent summary fron a real business plan. In this study, the entire plan was examined, not just the management summary. Inclusion of the summary is intended to substitute for the more lengthy business plan while still providing sone insight into the coding process. The summary is censored for conridentiality. 
Key items are underlined. The underlined items are then coded on the data collection form.

As ambiguities became apparent, variables were more closely Jefined and new coding conventions were added so that further coding was consistent. For example, even a fairly explicit variable such as high market growth rate or market growth rate over $20 \% /$ year (v1) appeared ambiguous when it wasn't clear whether the growth rate was stated in real or inflated dollars. Coding convention was revised so that growth rates were assumed to be in real terms unless otherwise stated and inflation was assumed at $8 \% /$ year unless otherwise stated.

The practice of coding simple presence of a variable linited the types of interpretation that can be made fron this data in two ways:

1) While presence of a variable means that the condition, objective or action plan is explicitly stated, absence may mean that the opposite is true, that the particular variable is not mentioned, or that the particular variable was mentioned but discounted explicitly as beirs irrelevant to the actions taken or planned.

2) There is no tine frame associated with the coding of the presence of a variable. It is therefore impossible to distinguish loneterm strategies, objectives or changes in conditions. This limitation in variable coding required some additional coding conventions. For example, if the proposed strategy is "we will do a and after 3 years, we will do $b^{\prime \prime}$, both $a$ and $b$ were coded as present unless some condition(s) were stated as triggering conditions for implementing b.

\section{Data Tabulation}

Data collecied on the occurrence of variables 1-27 vere tabulated 
for frequency and conditional frequency using the SPSS crosstabs program. (Nie et al 1975 , 218)

Data Analysis

For each data set, the chi-square statistic was used to identify significantly related paired associations between conditions (v1-v17) and actions (v18-v27). (Kendenhall 1975, 284) Those joint frequencies for chi-square with a<. 1 were selected as significant and an SPSS computed $\phi$ statistic was examined for these joint frequencies. $\phi$ statistic measures strenEth of relationship and approaches 0 if the relationship appears significant due to chance. (Nie et al 1975, 224)

CORPORATE CONSISTEHCY: CONTENT SIMILARITY AINONG BUSIMESS PLAHS

Rationale for Similarity Coefficient Calculation

The following sinilarity test addresses the objection raised in Chapter II: analysis of paired associations among condition-strategy sets doesn't capture the complexity of strategic plan logic.

The similarity test used was called a coefficient of relationsinips, matching coeffient, or coefficient of asscciation. This coefficient measures resemblance or sinilarity among selected pairs of entities. In this test, resemblance of strategies is measured anong those plans which share common condition variables. Resemblance amons condition sets is measured for plans which propose the same actions.

If the model is correct, plans which share the same condition set. should be more similar than those which don't. The most significant condition variables in planning actions should show the most similarity anong the action sets of plans which include this condition. The 
similarity coefficient for the wost significant condition variables should be lowest when similarity of action sets is. weasured for plans which don't agree on the presence of these concition variables. The expected content model shows the nost actions positively associatec vith market growth rate and frowth objective (v2, v7). These variables are expected to show the most difference in similarity coeficients betwecn the pairs of plans wich agree on the presence of these conditions and those wihich don't agree.

A key assumption in the expected content model is that conditions serve as the plannine prenises for proposinc actions. The similarity Weasure can also be usec to examine the first cojection to this nociel: since current activities play a dominant role in developing actions, actions serve as the prenises on which assumptions about conditions are developed. Sinilarity coefrients measurine condition set similarity anong plans whici: agree on a jarticular action can be coupared hitin similarity coefficents lieasurine action set agreenent for condition variables. Ir comitment to a particular action is tine basis for plan content, similarity coefficents measurinti tie concition set sililarity should be higiner.

\section{Sinilarity Coeficient Calculation}

Several different coefficients of similarity have been developed for different applications. All are based on a pairwise couparisou of cases. Each case is conpared with every otrier case along a nuniver of variables or characteristics.

In this test, cases can only be called similar with respect to a particular variable (v1-v27) when they asree on its presence. In 
addition, there is no reason to weight positively matched pairs any differently than other pairs. The similarity coefficient which meets these criteria is the Coefficient of Jaccard (Sneath) which Sokol and Sneath (1963, 196) argue is the most promising for most taxonomic work. The Coefficient of Jaccard expresses similarity as the proportion of positive matches relative to all potential matches. Or,

$$
S j=N j k /(N j k+U)
$$

where $\mathrm{HJK}$ is positive matches and $\mathrm{U}$ is all unmatched.

In order to facilitate comparison of similarity coefficients anone data sets, $S j$ is further expressed relative to average the average frequency with which variables in the character set appeared. Or,

$$
S j(p)=N j k /(N j k+U) * F
$$

where

$$
\mathrm{F}=\mathrm{P} / \mathrm{n} \approx \mathrm{m}
$$

where $n=$ number of characters, $m=$ number of cases, $P=$ number of positive responses.

BASIC prograns which selected and compared cases which agreed on the presence of a particular variable (v1-v27 above) and calculated similarity coeffients for the response set associated with that variable are shown in Appendix A (p.123). Similar programs were used to calculate both "agreement scores" and "disagreement scores". The "agreement score" for a premise variable is the similarity coefficient calculated for those plans which agreed on the presence of this prewise variable. The "disagreement score" for a prewise variable is the similarity coefficient for those plans which disagreed on the presence of this premise variable. 


\section{FACTOR ANALYSIS: IDEHTIFYING COMPLEX COIPONEITS OF STRATEGY}

A general assumption behind the expected content model is that strategy setting is based on a consistent association arong key variables. The expected content model is more specific in that it proposes the consistent association between pairs of variables, one of which is a condition and the other an action. Factor analysis is used as an exploratory model building tool to identify other possibly stronger associations among variables whici aren't pairwise and don't depend on a distinction between conditions and actions. (Fumel 1976)

If the expected content model is correct, the variables clustereci on a particular factor should reflect the matrix shown in Figure 1 (p. 6). Hore complex clusters of variables on a particular factor would indicate a more complex approach to strategy formulation.

Because factor analysis is intended here as a technique for clustering variables ratier than for fitting a linear nodel, factor analysis could be applieo to raw data which was nominal ( 0 or 1 indicatinf either presence or absence of a character). Joint frequencies calculated earlier using the SPSS crosstabs progran vere substituted for correlation coefficient, and the riatrix of joint frequencies was subnitted in SPSS matrix fornat to the SPSS factor routine. PAl factor routine (makes no assurptions about data structure) and varinax rotation (simplifies factor matrix columns) were used. (Nie et al 1975) This factor analysis application is not dissimilar to the clustering application of factor analysis discussed by Sokol and Sneath. (1963) They sugfest that factor loading results be interpreted as the 
higher the factor loading, the more typical the variable of the factor.

\section{NON-COITEHT DESCRIPTORS OF CORPORATE PLANS}

If plan content were heavily influenced by the short-term: operating context in which planning takes place, one would expect a close association between plan year, past performance and short-terri forecasts, and the presence of variables describine content. One woulc expect an especially close relationship between plan year and plan content if short-term corporate-wide concerns doninated the planring process. If short-tera business unit operatinë concerus were dowinant, one would expect that recent performance and short tern forecasts would be closely associated with content variables.

Seven additional variables were selected to describe the formal plans. These variables are sumarized in Table II (p.54). Variables, v29-v34 describe past performance and forecast performance for sales growth and profitability. These variables were introduced in order to check whether recent performance or plan objectives contributed to variations in plan content. These perfornance measures and objectives were included in all plans, althougin plans from the first year that the business was organized as a business unit typically did not include data on past performance $(\mathrm{v} 29, \mathrm{v} 30)$. Because the speciric measures of past and forecast growth and past and forecast profitability varied frow year to year, business plans were ranked relative to other business plans for the same year and coded as follows:

\footnotetext{
1 high growth or profitability (top fifth of businesses for that year)
} 
TABLE II

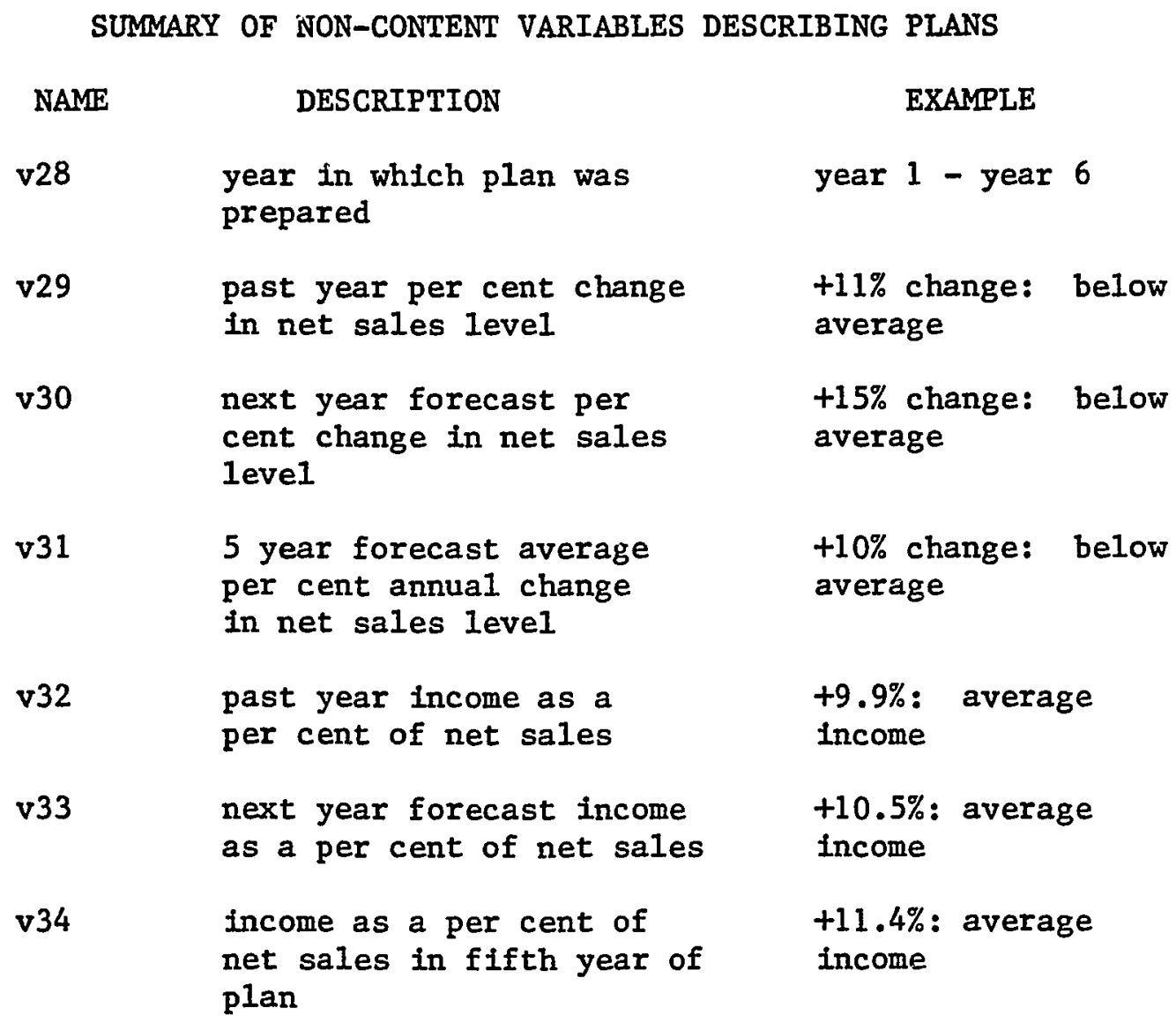




\footnotetext{
2 above average growth or profitability (2nd fifth of businesses for that year)

3 average Erowth or profitability (niddle fifth of businesses for that year)

4 below average growth or profitability (4th fifth of businesses for that year)

5 lowest Erowth or profitability (botton fifth of businesses for that year)
}

The SPSS crosstabs prosran was used to tabulate the joint frequency with which each content variable appeared with eaci of the six plan years and with each of the five ranisings of the seven variables describing past and forecast performance. As in the previous section, SPSS-conputed tests for significance and strength of relationship were used. Chi-square test was used as a test of significance. Craner's V test was used to determine strength of significant relationships. Craner's $V$ is based on the $\phi$ test described earlier and adjusts for tables larger than 2x2. (Nie et al 1975, 224)

\section{PLANIIIG EXERCISE: PLANHIIIG PROCESS VS PLANHIHG LOEIC}

The intent behind involving Fast Delta Corporation managers in this planninf exercise was to compare the content of plans developed using two different processes. The first process is that implied by the expected content model. The second is dependent on manager comilitment to current activities. Results of this experiment were compared with both the expected content model and with actual formal plan content. In addition, data collected on the professional backgrounds of manasers allowed further analysis of the organizational constraints imposed on 
planning locic.

\section{Planning Exercise Participants}

Business unit general managers, functional managers and staff directly reporting to business unit managers typically participate in the business planning process. Therefore, these managers were selected for participation in this exercise. These managers were identified through the corporate roster. Approximately $80 \%$ of this study population was asked to complete two exercises in planning and to answer three questions about their professional background and position. The reasons the remaining $20 \%$ were not asked to complete the questionnaire are discussed in a following section ( $p .57$ ).

\section{Questionnaire Development: Part A and Part B}

A preliminary questionnaire asking managers to plan usinf two different processes was developed and tested on five nanagers. Because responses to the exercise requiring that managers ignore the noruative process could not be coded using condition variables 1-17, this portion of the questionnaire was revised to require more specific answers.

A sample of the final questionnaire is shown in Appendix $D$ (p.140).

In the first exercise, part A, respondents were provided with a description of a hypothetical business' current conditions. The case study could be characterized as the presence of high market growth rate, low relative market share, profit growth objective, market share growtin objective, design skill strength, and high quality products (v1, v3, v6,v7,v11,v14, see Table I, p. 7.) Variables were chosen in order to 
create a realistic case and in order to test the expected content model. Respondents were asked to suggest appropriate action strategies which matched these conditions. If the expected content model were relevant to managers' planning logic most participants should respond with the same action suggestions: to increase productivity, increase marketing effort, increase product quality, market new products to current markets, or divest (v18, v19, v21, v23, v25, v27, see Table I, p. 7 ).

In part B, respondents were provided with an arbitrary set of action strategies and asked to suegest the conditions under which this action set might be successful. The stratery was characterized as the presence of actions to increase productivity, warket new products to current markets and market new products to new markets. ( v18, v23, v25, see Table I, p. 7.) The expected content model suggests that sone condition variables ( 1 , v2, v3, v6, v7, v8, v9, v10, v11) should be paired with these action variables. However, since the process required to complete part $B$ is backwards from the normative process, responses should show little pattern compared to the responses to part A. Part C is discussed in the last section of Chapter III (p.62) and requests infornation about participant background. Response forwat in parts A and $B$ was open-ended but response time for all parts was linited to ten ninutes.

\section{Administering Questionnaires}

Participants were asked individually or during business unit staff meetings to participate in this study. All those who were asked completed the questionnaire. The questionnaire was adrinistered to 
participants individually or in small groups of less than five managers. In order to provide some individual anonymity, questionnaires were identified by group (business unit) code only. The managers who did not complete questionnaires were those who were absent from the staff meetine on the day questionnaires were distributed or those who proved unreachable by phone after several tries. Hanagers from each of the Fast Delta Corporation business units were included in this study. Participants who completed the questionnaire in small groups completed it without discussion amon eaci other. All participants completed the questionnaire within ten ninutes.

\section{Codini Questionnaire Responses}

Case study content and participants' responses were coded for the presence of strategic content variables using the codirg method described in the first section of Chapter III,(p.45). In part A, case study condition variables were coded as presence of $v 1, v 3, v 6, v 7, v 11$, and v14, and participants' responses were coded for v18-v27. In part B, participants' responses were coded for v1-v17, and case study-specified action variables were coded as presence of $118, \mathrm{v} 23, \mathrm{v} 25$.

In sone cases participants requested additional information. These requests were noted separately. For example, in part A, participants sometines requested more information about overall technological position. Other participants indirectly requested more information by making action plans conditional on the presence of sone condition variable which had not been addressed in the case study. Coding difficulties were similar to those encountered in coding plans. Responses which could not be matched with variables were ignored. 
If a response overlapped two variables both variables were coded as present.

Appendix D (p.140) includes an example of a coupleted questionnaire and coding for this response.

\section{Analysis of Questionnaire Results}

SPSS crosstabs programs were used to summarize the frequency witin which each variable appeared in each part of the questionnaire. Chi-square statistia was used to indicate significant joint frequencies and Cramers $V$ was used to indicate strength of relationship for those joint frequencies for chi-square with a<.1.

RELATIVE CORPORATE CONSISTENCY: COHPARISON OF FORIAL PLAI CONTEIT

VS BUSINESS CASE STUDY COHTENT

Comparison of formal plan content with the strategic logic evidenced in case studies allows the identification of the dewree of constraint imposed on plan lofic by The Corporation. If Fast Delta Corporation were completely diversified, there shoulu be no difference in similarity coefficients between plans from the same company and plans from a variety of different companies.

\section{Case Study Selection}

Data describing the coincidence of assumptions about conditions with actions taken or action plans were collected from business strategy case studies. A sample of 105 case studies was collected fron the business strategy sections of Business lieek and Electronic Business. These case studies represent nearly $100 \%$ of the case studies presented 
in Electronic Business during 1977-1979 whicis were lonser than about 800-1000 words. Case studies frow Business lieek represented about $70 \%$ of case studies printed in 1978-1979 which dealt with industrial products manufacturing coipanies. See Appendix E (p146) for case study references.

Differences Between Case Studies and Formal Plais

It was expected that case studies frori popular läjazines woulc differ frow Corporation business plans. First, the case studies vere shorter. Second, case studies vere witten for a different purpose anc: for a difierent aldience than the purpose and audience for the Corporation business plans. Generally, the case stldies vere intsnciec to illustrate a jusiness success story. Because the audience for case studies was the public, ley variables nay have been onittec. Finally, the case studies described asstimptions vilicl: proved correct and actions which were tal:en rather than tentative assuptions and planned actions.

\section{Sigilarity Coeficient Celculation}

Data fron these sources were coded lising the sare proceciures as described in the previous sections. Appendix $E(p .146)$ also incluces the results of this codine process. Similar dirifulties vere encountered. The same sinilarity calculations described previously were performed with cata describine case studies. Sinilar BASIC prozräE were used. (See Appendix C, p.128) 
PLANHIHG EXERCISE: PLAMIIIG LOGIC AHD liAMGERS' PROFESSIOHAL CHARACTERISTICS

The expected content model does not deal with differences in strateäic logic based on organizational experience or orsanizationel culture and processes. Objections to the expected content model suisest that this makes tre nodel less useful. Relationships ioentiried betreen the wanacer professional characteristics collected in part $C$ of tise questionnaire and the stratejic logic identified in parts $f$ and $D$ could throw sose liblht on the deviations oí stratesic plan content fron tire Expectes content model.

As in the exanination of stratejic plan content, banajeri' responses were examined in two alterrative ways. First, sijnificant joint frequencies between variables describing the strategic content of wanagers' responses and variables describine the nanäers' professional characteristics were identified. Second, sinilarity anong croups of nanagers with respect to strateöic losic was exalined.

If the expected content model described the strategic losic usec by Corporation manasers, there should be no sicnificant association between content and professional characteristics. Sinilarity should be higher in part $A$ than in part $B$, and there should be no differences in similarity between Eroups. Discussion of objections to tris wociel sugeests that: either similarity should be hisiner witi longer lensth or service and with higher managesent level; similarity should be hiöher within professional groups; and/or sinilarity should be hicher in part $D$ than in part A. In addition, sicnificant joint frequencies of professional characteristics and content variables should occur. 
Part $C$ of the questionnaire submitted to participants asked managers to supply the following information on their professional background: length of service, training, and management level. Questionnaire format for Part $C$ was multiple choice with choices intended to develop three approximately equal groupings of managers for each of the three questions. Response categories and coding are shown in Table III $(p .63)$.

SPSS crosstabs program was used to tabulate joint frequencies of each category with the 27 plan content variables characterizing managers' answers to parts $A$ and $B$. Significance and strength of relationship were calculated using the SPSS Chi-square and Cramers V tests as described in previous sections.

Similarity coefficients for parts A and B were also calculated for each of the nine subgroups of managers identified through part $C$. BASIC programs similar to those used above to calculate similarity coefficients are shown in Appendix $c,(p, 128)$

SUMRAAY

This chapter discussed the methods used in this study. Preliminary steps included the selection and definition of content variables and the development of an expected content model. Fast Delta Corporation strategic business plans were coded for presence of content variables and compared against content expectations. Matching coefficient and factor analyses were also used to examine plan content. Other tests used to explore planning process and content in the study firm were aimed at examining the impact of planning- process and 
TABLE III

VARIABLES USED TO DESCRIBE PROFESSIONAL EXPERIENCE OF QUESTIONNAIRE RESPONDENTS

NAME

DESCRIPTION

EXARIPLE

v35 Length of Service at The Corporation

1 less than 8 years

28 - 15 years

3 more than 15 years

v36

Primary Functional

Background

1 eng ineering

2 manufacturing

3 marketing

4 general business

5 other

v37 Management Level

1 genera1 manager

2 functional manager

3 other (staff) 
organizational constraints on content. These tests included couparison of plan content with other plan characteristics, couparison of plan content with the strateisy content of business case studies anci examination of the results of interviens with Fast Delta Corporation managers. Interviei format consisted of a questionnaire which asised wanajers to plan business strategy using two dirferent processes. Tine content results of each process were compared with tile eapected plan content model. Plannine ezercise content anc nanager baciorounc were also coupared usine correlation coespicient and watchin coefricient analysis. 
CHAPTER IV

RESULTS

GOODHESS OF FIT TEST: EXPECTED CONTEITT HODEL VS ACTUAL PLAI COHTEIT

Significant pairec relationships arione variables describinê assunptions and actions in Fast Delta Corporation formal plans are shom in lable IV (p.66). The expected content model predictec that certain pairs of action and assumption variables should be present in the business unit plans. Table IV is divided into a list of those variables which were present as predicted by the nociel and those pairs of variables which were identified as strongly associated but vere not predicted by the wociel. Table IV also includes discussion of individual pairs of variables. Alternative explanations for the absence of sone variable pairs and the presence of otiers are discussed in followin sections.

of the 28 significant joint irrequencies predicted by the vodel, this approach checked for only 17. Only significant joint frequencies for variables occurring with more than $15 \%$ frequency were checked for. The 15\% frequency cut-off was chosen to compensate for relatively snall sanple size and very low joint frequencies for pairs where variables occurred less than $15 \%$ of the time. This meant that even though product high contribution margin and actions to increase vertical integration, market new products to new markets, change market structure, anc divest 
TABLE IV

SUMMARY OF CONTENT VARIABLE PAIRS WITH SIGNIFICANT JOINT FREQUENCIES

\begin{tabular}{lccc}
\multicolumn{4}{c}{ EXPECTED } \\
NAME & $\chi^{2}$ & $\phi$ & DASED ON BASIC MODEL \\
v1-v23 & .05 & .20 & expected \\
v2-v21 & .07 & .19 & expected \\
v7-v21 & .02 & .24 & expected \\
v12-v22 & .01 & .28 & expected
\end{tabular}

HOT EXPECTED - BASED ON BASIC MODEL
NAME


TABLE IV (CONTINUED)

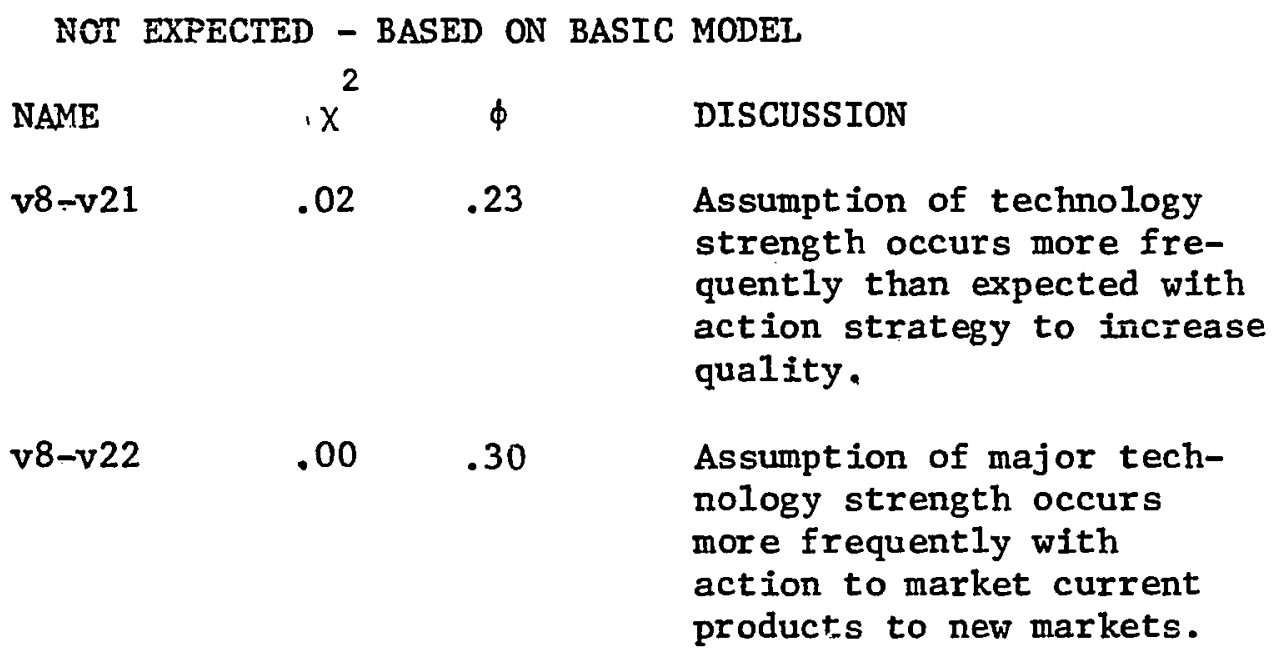


(v17, v20, v25, v26, and v27) were coded, this analysis did not adiress expected pairs which included these variables. of the 17 renainini expected joint frequencies, four actually appeared and four other significant joint frequencies which were not expected appeared.

The results of chi-square and $\phi$ tests for significant and strongly related variable pairs are also shown in Table IV (p. 66).

lissing expected variable pairs were spread throughout the matrix or expected pairs (See Figure 1, p. 6). Associations with absolute and relative market share(v2 and v3), profit objective (v6) and vitis procilict cinaracteristics (v13-v16) were not present as expected. The unexpected pairs related to the assunption of technology strength (v8).

CORPORATE CORSISTEICY: SIIILARITY COEFFICIEITS FOR CORPORKIOH PLAM

This section discusses test results ôे corporation plans for association between a prenise variable and a pacliaice of resultant variables.

Table V (p.69) shors the agreenent score (sinilarity coeficicient for plans which agree on a preuise variable) and disarreenent score (similarity coefficient for plans which don't agree or 2 premise variable) for each variable. Table VI (p.70) Eroups variables by relative difference in similarity coeficient. Althougn all sinilarity coeriticients were higher under agreenent on the presence of the preaise variable, differences betiveen agreement and disagreenent were not very large. Only five of 14 showed differences of nore than 10\%. lione showed a difference larger than 20\%. Only three of five condition similarity coeficients showed differences larger than $10 \%$ and none 
TABLE V

COMPARISON OF SIMILARITY COEFFICIENTS UNDER AGREEMENT AND DISAGREEMENT FOR CONDITION AND FOR ACTION VARIABLES FOR FORMAL PLANS

$\begin{array}{ccc}\text { NAME } & \text { AGREE } & \text { DISAGRE } \\ \text { v1 } & .437 & .378 \\ \text { v2 } & .396 & .363 \\ \text { v3 } & .378 & .367 \\ \text { v4 } & .404 & .356 \\ \text { v5 } & .411 & .351 \\ \text { v6 } & .400 & .367 \\ \text { v7 } & .357 & .363 \\ \text { v8 } & .415 & .359 \\ \text { v9 } & .385 & .355 \\ \text { v11 } & .319 & .351 \\ \text { v12 } & .393 & .378 \\ \text { v14 } & .374 & .370 \\ \text { v15 } & .381 & .367 \\ \text { v16 } & .430 & .378\end{array}$

(Average frequency of actions $=.27$ )

$\begin{array}{lll}\text { v18 } & .535 & .506 \\ \text { v19 } & .496 & .499 \\ \text { v21 } & .569 & .501 \\ \text { v22 } & .647 & .538 \\ \text { v23 } & .577 & .504 \\ \text { v24 } & .506 & .499\end{array}$

(Average frequency of conditions $=.39$ ) 
TABLE VI

\section{SUMMARY OF RELATIVE AGREEMENT-DISGREEMENT SCORE DIFFERENCES}

RELATIVE

DIFFERENCE

variables

showing $20 \%$

difference

variables

showing

$10-20 \%$

difference

variables showing less

than $10 \%$

difference
NAME

$\mathrm{v} 1, \mathrm{v} 4, \mathrm{v} 5$, v8,v16,v21

v22, v23

v2,v3,v6, v7,v9,v11

v12,v14,v15

v18,v19,v24 
showed differences larger than $20 \%$

While this approach suggested that some variables were more important than others in predicting action set, broad product line strength (v16) did not appear as a significant variable in the expecteci content model and did appear as a significant variable in this test of the formal plans. Hign market share and action to broaden line to current market (v2 and v24) were expected to shoi larger relative differences in similarity and showed no differences instead. Actions to increase perceived product quality, narket current products to nen segwents and warket new products to current segnents (v21, v22, v23) were expected to show larger relative dirferences and instead ranjei only 10-20\% disference.

STEATELIC FACTORS: FACTOR AIFLYSIS OF PLAI COMTEHT

Factor analysis was used to detect other patterns in the stratejic content of plans which aidn't conforn to the expected content nociel.

Hine factors accounted for nearly $90 \%$ of the variation in tire sample. Table VII (see p.72) sumarizes the factors includint eifen values, percentage of variance explained, and variables associated vith each factor. Figure $9(p, 73)$ shows the relationship detween the expected content model and the results of the factor analysis. Significant paired associations are marised if two variables appeared heavily loaded on the sane factor. Only eigint of the expected 28 relationships appeared and many more unexpected associations are identified. Two of the major factors identified include condition assumptions only. 
TABLE VII

RESULTS OF FACTOR ANALYSIS OF PLAN CONTENT

$\begin{array}{llllllllll}\text { FAC } & 1 & 2 & 3 & 4 & 5 & 6 & 7 & 8 & 9 \\ \text { EIG } & 12.3 & 2.0 & 1.8 & 1.6 & 1.4 & 1.3 & 1.2 & 1.0 & \\ \text { VAR } & 45.5 & 7.4 & 6.5 & 6.1 & 5.8 & 5.3 & 4.9 & 4.5 & 3.7 \\ \text { V } & & & & & & & & & \\ 1 & .02 & .12 & .25 & .45 & .12 & .49 & .17 & .02 & .00 \\ 2 & .43 & .70 & .18 & -.03 & .22 & .29 & .15 & .16 & .27 \\ 3 & .20 & .09 & .42 & -.11 & .20 & .29 & .03 & .10 & .71 \\ 4 & .30 & .48 & .24 & .67 & .28 & .14 & .21 & .19 & .13 \\ 5 & .42 & .30 & .37 & .34 & .20 & .23 & .43 & .29 & .16 \\ 6 & .40 & .51 & -.13 & .07 & .18 & .20 & .08 & .36 & .36 \\ 7 & .11 & . .00 & .47 & .46 & .32 & .10 & .44 & .23 & .35 \\ 8 & .19 & .24 & .11 & .26 & .34 & .45 & .60 & .18 & .24 \\ 9 & .43 & .29 & .55 & -.02 & .33 & .24 & .27 & .53 & . .09 \\ 10 & .14 & .11 & .10 & .07 & .08 & .06 & .09 & .07 & .09 \\ 11 & .17 & .05 & . .09 & .31 & .10 & .02 & .22 & .12 & .84 \\ 12 & .19 & .25 & .09 & .25 & .16 & .46 & .68 & .01 & -.09 \\ 13 & . .00 & .07 & .13 & .04 & . .03 & . .01 & 1.0 & .03 & .18 \\ 14 & .35 & .40 & .29 & .15 & .45 & .43 & -.01 & -.05 & .19 \\ 15 & .07 & .22 & .20 & .46 & .29 & .30 & .08 & .45 & .09 \\ 16 & .09 & .49 & .24 & -.14 & .07 & .47 & .08 & .38 & .15 \\ 17 & .01 & 1.0 & .08 & .20 & .02 & -.02 & .15 & .00 & -.07 \\ 18 & .53 & .18 & .22 & .04 & .25 & .11 & .04 & .49 & .09 \\ 19 & .27 & .03 & .25 & .31 & .78 & .07 & .01 & .17 & -.03 \\ 20 & .00 & .12 & .04 & -.02 & 1.0 & .15 & .13 & .07 & .25 \\ 21 & .73 & .06 & .23 & .22 & .04 & .47 & .04 & .05 & .04 \\ 22 & .20 & .04 & .08 & .23 & .14 & .90 & .15 & .02 & .15 \\ 23 & .23 & .11 & .68 & .20 & .12 & .12 & .11 & .32 & .02 \\ 24 & .89 & .11 & .13 & .06 & .09 & .01 & .09 & . .00 & .20 \\ 25 & .12 & .08 & .94 & .14 & .09 & .09 & .10 & -.06 & .06 \\ 26 & .09 & .03 & .11 & .91 & .04 & .17 & .11 & .12 & .11 \\ 27 & . .00 & .02 & .05 & .20 & .03 & -.05 & .04 & .99 & .13 \\ & & & & & & & & & \end{array}$


ACTION VARIABLES

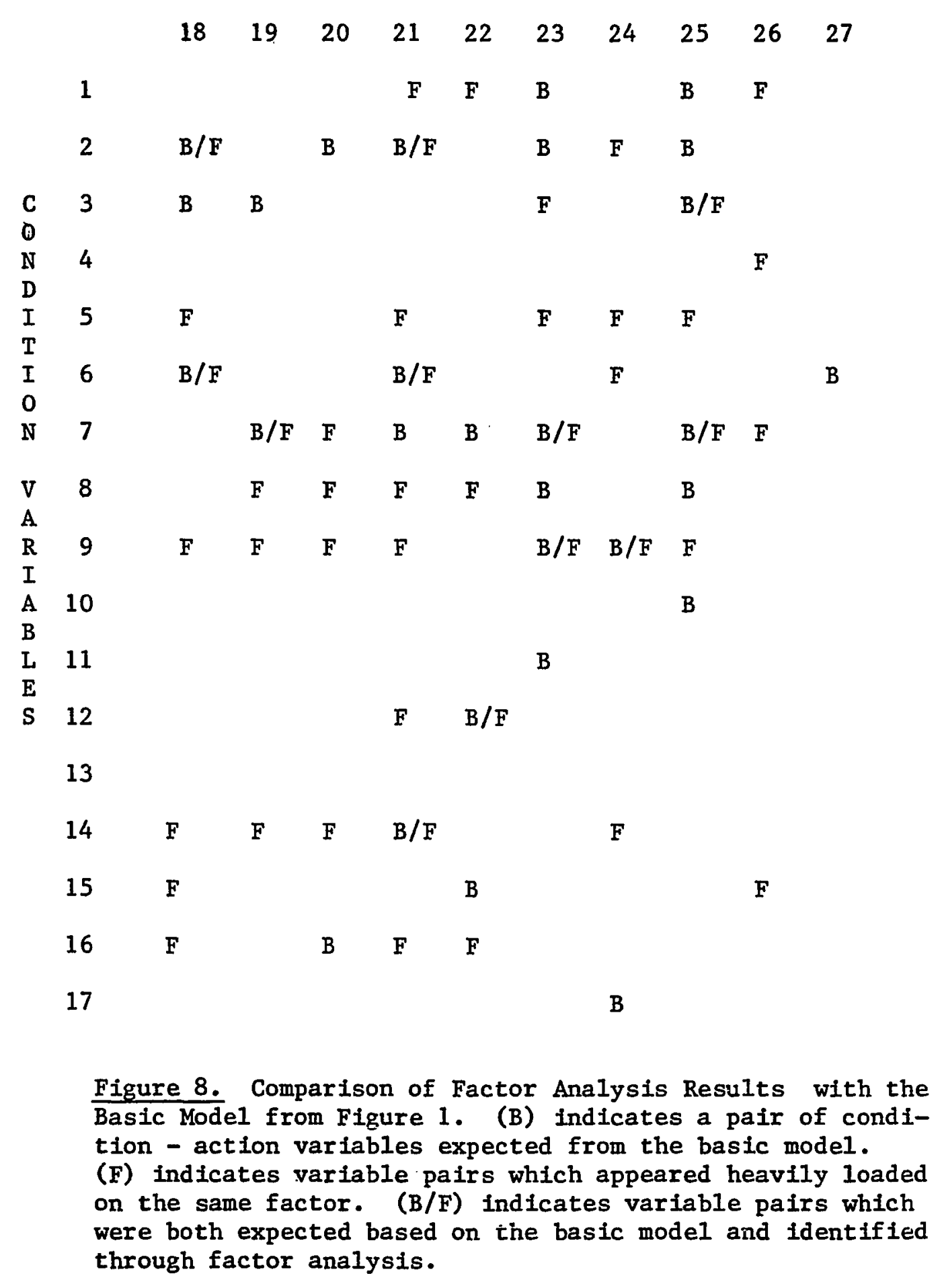


While factor 2 and $7(p .72)$ didn't include action variables, triej do include profit and market share jrowth objectives (v6, v7). Sizi of the seven factors explainine the most variance included significant loadings on at least one of these variables describine objectives. Sarrazin's (1977) sufgestion that objectives and forecasts are nore important plan content than action proposals is in part supported.

Ideally, one would have expected each factor to consist of very feir heavily loaded variables. Instead:

1) Host factors included more than a fe:; heavily loaded variables. Factor 1 (p.72), for example, (45.5\% of the variance), loaded heavily on the largest nuluber of variables. It characterized a business vitin laréce warket share and custower technological need as aajor wariet oriver. liajor objective was increased prorit and streneths were nariet stren,jth and product quality. ifajor actions were to decrease costs, increase quelity, and broaden the product line. Rather than describini business planninf principles, factor 1 and others appear as descriptive suinaries of the types of business in which The Corporation participates.

2) Ilost condition variables loaded at or above .4000 on nore thain one factor. This sugrests triat variables studied here as simple content variables actually had wore conjlex content for strategic plaming purposes. For exariple, high narket gronth rate (v1) was alnost equilly loadec on factors 4 and $6(p .72)$. Factors 4 and 6 shared no other cormon variables and "high mariset growth" appeared to have different implications for eacin factor. 
NOH-CONTENT DESCRIPTORS: PLAN CHARACTERISTICS AHD PLAIN COITLII'

Table VIII (p.76) surararizes variables which were significantly correlated with plan year and performance. Criteria for inclusion in this chart was that variables appear with greater than $15 \%$ frecuency over saraple, and a<.1. 0 tests indicatinê streneth of relationsinip rangec from .25 to .40 .

Significant variable frequency changes with tilie exhibited t::o patterns. The first was that pattern characteristic of hibl prociuct quality strenith and action to increase marketing exfort (v14 and v19). Durino the six-year period $v 14$ and $v 19$ appear at a signiricantly different frequency in one of the six years. This sliecests eititer a one-tine event sucin as a trainine prograli or a one-time corporate concern. Design skill strengtin and action to broacien product line to current narket (v11 and v24) exhibited öradual changes in frequency over time in what was nore lixely a change consistent with the expected content model. V11 and v24 were predicted by trie rociel to be closely associated and results here anci in "Goodness of Fit Test" (p.65) confiri.. this. Proíit đronth objective (vo) was associated uitin plan year oniy. This subrests that profit objective statements were tied to short teri. corporate soals and concerns.

Table IX (p. 77) sumarizes content variables which vere significantly associated with past performance and perforrance forecasts included in the business unit plans.

Correlations of nariset Growti rate, maricet share (v1, v2) witin profitability and growth performance and iorecasts were expected. The correlation of the Erowth objective (v7) with the five-year growti 
TABLE VIII

CONTENT VARIABLES SIGNIFICANTLY ASSOCIATED

WITH PLAN YEA'R

$\begin{array}{llll}\text { NAME } & x^{2} & V & \text { DISCUSSION } \\ \text { v6 } & .05 \quad .30 & \begin{array}{l}\text { The ratio of businesses listing this objective } \\ \text { to those not listing changes dramatically from } \\ \text { as high as } 1: 4 \text { in one year to as low as } 1: 2.5 \\ \text { in other years. This objective (increase profit) } \\ \text { appears closely tied to annual changes in finan- } \\ \text { cial objectives. }\end{array}\end{array}$

v11 $\quad .01 \quad .36$ This highly significant correlation was based on a variation of from $5 \%$ to $50 \%$ of the businesses including design skill as a major strength. No one explanation is satisfactory since planners may have valued this quality more in some years, competitive position may have changed, business mix may have changed, or corporate values may have changed.

v14 .05 .30 This significance score appears high because in one year, the number of businesses including this assumption (high product quality) was about onethird the average of other years.

v19 $\quad 10 \quad .2$ This signif icance score appears high because in one year, action to increase marketing effort appeared in twice as many plans as in other years. This suggests a corporate-wide concern for market position.

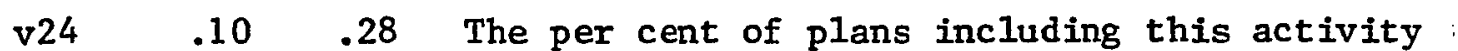
ranges from $28 \%$ to $62 \%$. Broadening product line represents a comparatively conservative approach for this industry. Data pattern suggests that if more history was available, this variable may follow a cyclic pattern. 
TABLE IX

\section{CONTENT VARIABLES SIGNIFICANTLY ASSOCIATED \\ WITH PAST PERFORMANCE AND PERFORMANCE \\ FORECASTS}

\begin{tabular}{|c|c|c|c|}
\hline NAME & $x^{2}$ & V & DISCUSSION \\
\hline v22-v29 & .08 & .30 & $\begin{array}{l}\text { Past relative sales growth and proposed action } \\
\text { to introduce a current product to a new market. } \\
\text { Almost half of the plans proposing this action } \\
\text { indicated previous year's growth at slightly } \\
\text { above average. }\end{array}$ \\
\hline v3-v30 & .03 & .33 & $\begin{array}{l}\text { I year growth forecast and assumption that market } \\
\text { was fragmented. More than a third of the plans } \\
\text { including this assumption forecast above average } \\
\text { growth the following year. However, a much } \\
\text { smaller protion forecast very high growth. }\end{array}$ \\
\hline v16-v30 & .03 & .24 & $\begin{array}{l}1 \text { year growth forecast and assumption that a } \\
\text { broad product line provides a major busiress } \\
\text { strength. More than a third of the plans includ- } \\
\text { ing this assumption forecast slightly below } \\
\text { average growth. }\end{array}$ \\
\hline v22-v30 & .02 & .34 & $\begin{array}{l}1 \text { year growth forecast and action proposal to } \\
\text { introduce current products to new markets. More } \\
\text { than two-thirds of the plans including this pro- } \\
\text { posal forecast above average or highest growth } \\
\text { forecasts for the following year. }\end{array}$ \\
\hline v1-v31 & .04 & .31 & $\begin{array}{l}5 \text { year growth forecast and assumption that mar- } \\
\text { ket was growing at a rapid rate. More than half } \\
\text { of the businesses including this assumption fore- } \\
\text { cast slightly above average or highest growth over } \\
5 \text { years. }\end{array}$ \\
\hline$v 7-v 31$ & .00 & .43 & $\begin{array}{l}5 \text { year growth forecast and major objective of } \\
\text { market share growth. More than half of the bus- } \\
\text { inesses including this assumption in their plans } \\
\text { forecast highest or above average growth over } \\
\text { the five year period. }\end{array}$ \\
\hline
\end{tabular}


TABLE IX (CONTINUED)

\begin{tabular}{|c|c|c|c|}
\hline NAME & $x^{2}$ & $\mathrm{~V}$ & DISCUSSION \\
\hline $2-v 33$ & .00 & $.4 \pi$ & $\begin{array}{l}1 \text { year profit forecast and the assumption of high } \\
\text { market share. One third of the businesses indi- } \\
\text { cating this market characteristic forecast above } \\
\text { average profitability. Three-quarters forecast } \\
\text { average to highest profitability. }\end{array}$ \\
\hline v4-v33 & .00 & .42 & $\begin{array}{l}\text { I year profit forecast and the assumption that } \\
\text { competitors' technological pressure was a major } \\
\text { market driver. Less than } 10 \% \text { of the businesses } \\
\text { reporting this assumption forecast the highest } \\
\text { profitability for the following year. }\end{array}$ \\
\hline v21-v34 & .02 & .33 & $\begin{array}{l}\text { profit forecast for the fifth year of the plan } \\
\text { and action proposal to increase quality. Almost } \\
\text { two-thirds of those businesses who planned to in- } \\
\text { crease product quality forecast above average or } \\
\text { or average profits for the fifth year of the plan. }\end{array}$ \\
\hline v15-v34 & .12 & .27 & $\begin{array}{l}\text { profit forecast for the fifth year of the plan } \\
\text { and assumption that highly differentiated products } \\
\text { provide a business strength. Almost three- } \\
\text { quarters of the businesses indicating this also } \\
\text { indicated above average profitability. }\end{array}$ \\
\hline v16-v34 & .12 & .27 & $\begin{array}{l}\text { profit forecast for the fifth year of the plan and } \\
\text { assumption that a broad product line was a busi- } \\
\text { ness strength. Almost half of the businesses } \\
\text { indicating this assumption forecast above average } \\
\text { profitability. }\end{array}$ \\
\hline
\end{tabular}


forecast was also expected; although if forecasts were nore key than content both profitability and growtin objectives (v6, v7) should have been associated with nore forecast neasures. Because more variables were associated with five-year forecasts than with past perforiuance, these results suggest that past performance was less relevant than forecast content to plan content. Of the 10 variables associated with forecasts, half were associated with short ter.i forecasts and hali were associated with lonk tern forecests. Of those variables associated with long-term forecasts, narket related variables were associated with Ionj-term growth forecasts and product related variables vere associated with long-teru profitability forecasts. This relationship was just reversed with respect to variables associated with short-teri: forecasts. Two of the three variables related to short-term frowtin were prociuct strengtis, and botr. variables related to siort teri profitability forecasts were ilariset related variables.

\section{PLAMIIHG EXERCISE: PLAHIIHG PROCESS AHD PLAMHIHG LOGIC}

Tables $Y(p .80)$ and $Y I(p .80)$ corpare questionnaire responses with wodel and with plan results. The expected content nodel vas precictive for part A results if one assumes as the Cyert and liarci: (1963) organizational process model does that conditions or problems were ranked in significance and responded to sequentially in that orcier. These results suggested that most participants ranked narket growth rate and market share Erowth objective ( $\mathrm{v} 1$ and $\mathrm{v} 7$ ) as nost important. Tine rodel suggested that $v 7$ was associated with three of the top eight higinest frequency responses. A nodel of expected response based on tile 
TABLE X

COMPARISON OF FART A RESULTS WITH BASIC MODEL AND WITH FORMAL PLAN RESULTS

$\begin{array}{cc}\text { V } & \text { FREQUENCY } \\ & \text { RESPONSE } \\ 18 & 32 \% \\ 19 & 65 \% \\ 20 & 11 \% \\ 21 & 27 \% \\ 22 & 49 \% \\ 23 & 40 \% \\ 24 & 11 \% \\ 25 & 27 \% \\ 26 & 13 \% \\ 27 & 5 \%\end{array}$

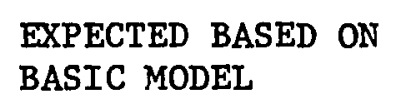

$\mathrm{v1,v3,v6}$

$\mathrm{v} 1, \mathrm{v} 3$

none

v6, v7, v14

v7

$\mathrm{v} 1, \mathrm{v} 7$

none

$\mathrm{v1}, \mathrm{v} 3, \mathrm{v} 7$

none

v3,v6
EXPECTED BASED ON FORMAL PLANS
v3
v7
none
v7
v1
$\mathrm{v} 1, \mathrm{v} 7$
v11
none
none
none

TABLE XI

COMPARISON OF PART B RESULTS WITH BASIC MODEL AND WITH FORMAL PLAN RESULTS

\section{V}

\section{FREQUENCY OF} RESPONSE

$\begin{array}{ll}1 & 36 \% \\ 2 & 31 \% \\ 3 & 18 \% \\ 4 & 10 \% \\ 6 & 29 \% \\ 7 & 13 \% \\ 8 & 15 \% \\ 9 & 44 \% \\ 10 & 41 \% \\ 11 & 16 \% \\ 14 & 11 \% \\ 17 & 52 \%\end{array}$

EXPECTED BASED ON BASIC MODEL

v23,v25
v18,v23,v25
v18,v25
none
none
v23,v25
v23,v25
v23
v25
v23
none
none

EXPECTED BASED ON FORMAL PLANS
v23
none
none
none
none
v23
none
none
none
none
none
none 
analysis of actual business plan content associated market share growth objective (v7) with three of the top six. The expected content nociel associates market growth rate (v1) with four of the six hichest frequency responses. A model based on actual business plan content associates two of the six hikhest frequency responses with v1. Hish relative market share (v3) also appears as a sienificant variable in that the model associates $v 3$ with three of trie hiohest frequency responses and one of the lovest. Fev, however, responded as if profit objective (v6) were significant. The profit objective vas also insienificant in the formal plan analysis.

One is left with the question, hovever, "what was the basis for the rankini of sionificant prenises to plannine?" Why did the Eroviti objective (v7) appear significant and the profit objective ( $v \sigma)$ ienored by fiost? The expected content fodel colid not predict whicii variables would be ranlied as most sicnificant.

A model based on actual content of stratejic business plans was nore helpful than the expected content wociel in precicting the results of part A. As in the expected content nodel, market gronth, relative market share, and market Growth objective (v1, v3, and v7) were significantly associated with highest frequency responses. Iits subsests that the e:sercise offered in part a can prociuce results similar to those which appeared in the results of the formal strategic planninf process. This means:

1) formal plans may be developed usins the normative process model required in part $A$; and,

2) there was little difference between the content wilich resulted 
from the fornal process and that resultine from informal and incivicual exercise required in part $A$.

The results of part $B$ sugsest no such consistent patterr. lieither the expected content model nor a model based on actual plan content was predictive of the highest frequency response set in part $B$. The process of evaluatinf current activities did not generate results similar to either the expected content model or a content rodel based on actual plan content.

While the purpose of tinis experinent was to identify and confare strategic planning content under two different planning processes, these differences may have been obscured or distorted by a less efífective preilise set in part E. Inromal participant comrents sugerested that this exercise was less stratejic, less interestine, and nore difíicult. In part A, 17 of 40 perticipants adued additional assunptions or wanted more information. In part $B$, only eight added alternative action proposals or wanted more information. Two sugEested that tine exercise was impossible and that the action proposal would de unsuccessful under any circuristances. In Eeneral, answers to part $E$ consisted of fewer words. This may have been because the question was second anci participants were operating under a tine linit, or it nay have been because participants found the question too simple ana less strategically focussed.

RELATIVE CORPORATE COHSISTEHCY: SIHLARITY AHOHG BUSINESS CASE STUDIESS VS SIIILARITY AMOIGG FORIIAL PLAIS

Tables XII (p.83), XIII (p.84), and XIV (p.85) compare similarity 
TABLE XII

COMPARISON OF SIMILARITY COEFFICIENTS UNDER AGREEMENT AND DISAGREEMENT FOR CONDITION VARIABLES BETWEEN FORMAL PLANS AND CASE STUDIES

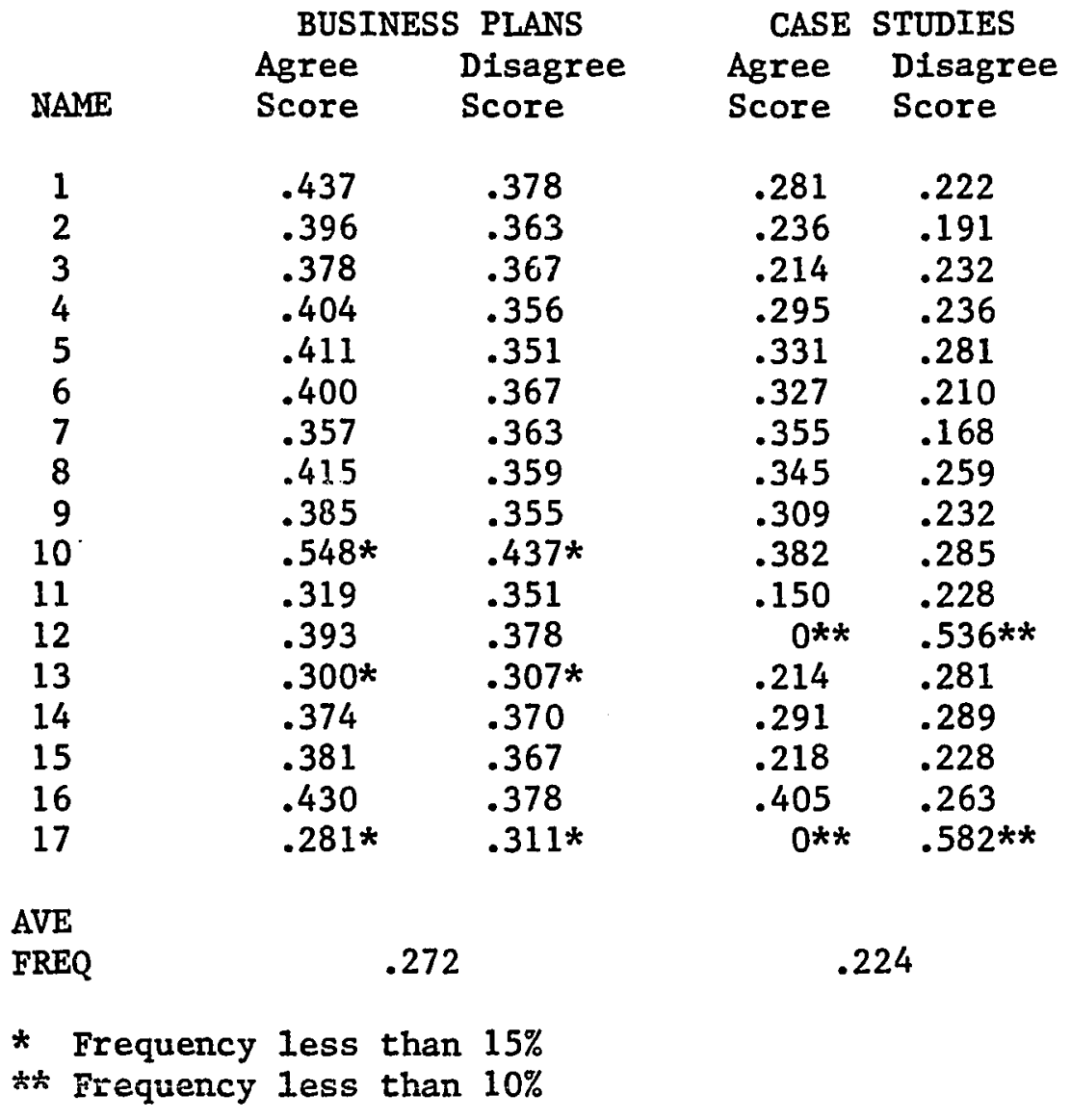


TABLE XIII

COMPARISON OF SIMILARITY COEFFICIENTS UNDER AGREEMENT AND DISAGREEMENT FOR ACTION VARIABLES BETWEEN BETWEEN FORMAL PLANS AND CASE STUDIES

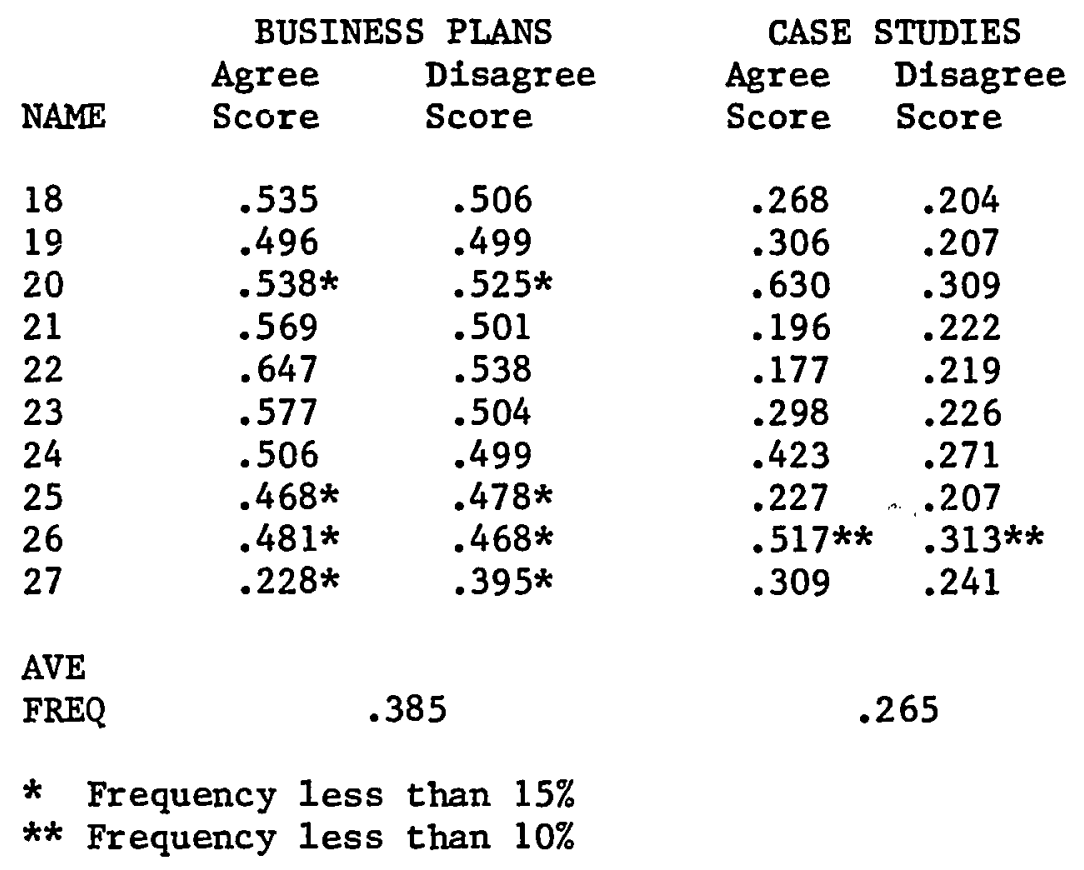


TABLE XIV

SUMMARY OF RELATIVE AGREEMENT-DISAGREEMENT SCORE DIFFERENCES

\begin{tabular}{|c|c|c|}
\hline & $\begin{array}{c}\text { BUSINESS } \\
\text { PLANS }\end{array}$ & $\begin{array}{c}\text { CASE } \\
\text { STUDIES }\end{array}$ \\
\hline $\begin{array}{l}\text { Variables } \\
\text { showing more } \\
\text { than } 20 \% \\
\text { difference }\end{array}$ & - & $\begin{array}{l}\text { v1, v2, v4, v6, } \\
\text { v7, v8, v9, v10, } \\
\text { v16, v18, v19, } \\
\text { v20, v23, v24, } \\
\text { v27 }\end{array}$ \\
\hline $\begin{array}{l}\text { Variables } \\
\text { showing } \\
10 \%-20 \% \\
\text { difference }\end{array}$ & $\begin{array}{l}\text { v1, v4, v5, v8, } \\
\text { v16, v21, v22, } \\
\text { v23 }\end{array}$ & $\mathrm{v} 5, \mathrm{v} 25$ \\
\hline $\begin{array}{l}\text { Variables } \\
\text { showing less } \\
\text { than } 10 \% \\
\text { difference }\end{array}$ & $\begin{array}{l}\text { v2, v3, v6,v7, } \\
\text { v9, v11, v12, } \\
\text { v14, v15, v18, } \\
\text { v19, v24 }\end{array}$ & $\begin{array}{l}\text { v3, v11, v13, } \\
\text { v14, v15, v21, } \\
\text { v22 }\end{array}$ \\
\hline
\end{tabular}


coefficients for case studies with similarity coefficients for forral Corporation business plans. Tables XII and XIII show a siliilarity coefficient under agreenent for each assurption variable and acticn variable in colums 1 and 3 of these tables. The sinilarity coefficient disagreement score for each assumption variable and action variable is shown in coluuns 2 and 4 . Scores for Corporation forral plan cases are shown in coluruns 1 and 2. Scores For business case studies are shown in coluuns 3 and 4. Table XIV sumarizes these results by Grouping variables by the relative difference betideen similarity coefficients under agreement and disagreement.

Each data source shows variables with higher coefficients for agreeing premise variables than for disagreeing prenise variables. Case studies showed bigôer relative differences anon̈̈ agreement and disagreement similarity coefíicients for more variables. Forwal plans showed much smaller relative differences, In Eeneral, case studies appear to conforn nore closely with the expected content Eodel. ilost variables which were expected to appear as significant actually showed the sipacted larger relative differences among similarity coefficients.

Or the other hand, Tables XIII (p.84) and XIV (p.85) showed that for Corporation plans, both action and condition scores were generally higher whether they were based on agreenent or disagreement. This suggests that no matter what assumptions, Corporation forral plans tended to include similar packages of actions. 
PLANNING EXERCISE: HANAGERS' PROFESSIONAL CHARACTERISTICS

VS PLAWHING LOGIC

Analysis of the influence of manajers' professional characteristics on planning logic took two forms: the first was a single comparison of background and content variable joint frequencies; and the second was tine developtient of agreenent scores for specific SUbEroups of ilanagers.

Content Variables and ianarers' Characteristias

Questions 1-3 asied participants to indicate (1) length of service at The Corporation, (2) backiround or discipline, anc (3) organization level. The following discussion sumarizes significant joint frequencies between these characteristics (v35-v37) and plan content $\operatorname{logic}(\mathrm{v} 1-\mathrm{v} 27)$

Question 1: "How many years have you worked at The Corporation?" Forty percent of the respondents reported that tiney had worked at The Corporation for less than eight years; 25\% had worked at the site for 8-15 years and 35\% had a length of service longer than 15 years. Assumption descriptive variables market fragmentation ( 33 ), and conpany technological strength (v8) and action descriptive variables of fer new products to current market (v23) were significantly related to the participants' length of service. See Table XV (p.88).

Question 2: "In whicli area do you feel you have the most experience and training?" Engineering provided the their background and experience $35 \%$ of the respondents; $17.5 \%$ reported a manufacturine background; $40 \%$ reported a marketing background; 5\% reported a seneral 
TABLE XV

SUMMARY OF CONTENT VARIABLES SIGNIFICANTLY

RELATED WITH LENGTH OF SERVICE

\begin{tabular}{|c|c|c|c|}
\hline NAME & $x^{2}$ & V & DISCUSSION \\
\hline V3 & .09 & .17 & $\begin{array}{l}\text { A much smaller percentage of those with } \\
\text { less than } 8 \text { years experience indicated } \\
\text { this condition as important ( } 13 \% \text { ) com- } \\
\text { pared to } 56 \% \text { of those with } 8-15 \text { years } \\
\text { experience and } 24 \% \text { of those with more } \\
\text { than } 15 \text { years experience who indicated } \\
\text { this condition as a key pre requisite to } \\
\text { pursueing actions described in part B. }\end{array}$ \\
\hline V8 & .09 & .22 & $\begin{array}{l}\text { While there was no significant differ- } \\
\text { ence on part B responses between these } \\
\text { three groups, } 21 \% \text { of those with more } \\
\text { than } 15 \text { years experience added this } \\
\text { condition to the conditions listed in } \\
\text { part } A .0 \% \text { of those with } 8-15 \text { years } \\
\text { experience added this condition. }\end{array}$ \\
\hline V23 & .01 & .24 & $\begin{array}{l}\text { Only } 19 \% \text { of those with less than } 8 \\
\text { years experience suggested that offering } \\
\text { new products to a current market was an } \\
\text { appropriate action for conditions listed } \\
\text { in Part } A . \quad 30 \% \text { of those with } 8-15 \text { years } \\
\text { experience and } 64 \% \text { of those with more than } \\
15 \text { years esperience suggested this action. }\end{array}$ \\
\hline
\end{tabular}


business background, and $2.5^{\circ}$ reported "other". Assumption-descriptive variables company strong technological position (v8), product quality or performance as a business strength) (v14), and high contribution uargin (v17) and action descriptive variables increase marketing/sales effort (v19) and increase vertical integration (v20) were significantly related to the baciground reported by participants. See Table XVI (p.90).

Question 3: "What position do you now hold?" General wanagers accounted for $22.5 \%$ of the respondents; $60 \%$ were managers of functional areas such as marketinE, manufacturing or engineering; $12.5 \%$ reported "other" such as staff positions within a general business or functional area. Only two action descriptive variables were significantly associated with differences in reportine level described by the responses to this question: restructure market segments or market (v26) and divest or discontinue product line (v27). See Table xVII (p. 91 ).

In general, reportins level (question 3) appeared to make little difference to the frequency with wich participants sugsested particular actions and conditions. Those with more experience (question 1) gave more significance to overall technolosical position and strength ano suggested introducing new products to current marliets as a wore relevant action stratezy. Those with mecilub experience expressed nore concern about competitive position, especially relative market share.

Bacliground (question 2) appeared to affect conditions and actions proposed in more ways than experience. The association of bacliground with particular variables in part explained the variation in managenent response reported in "Planning Exercise: Planning Process" (p.79). Managers responded with concerns in part B and with plans in part A 
TABLE XVI

SUMMARY OF CONTENT VARIABLES SIGNIFICANTLY

RELATED WITH FUICTIONAL EXPERIENCE

\begin{tabular}{|c|c|c|c|}
\hline & 2 & & \\
\hline NAME & $x$ & V & DISCUSSION \\
\hline V8 & .00 & .40 & $\begin{array}{l}28.6 \% \text { of those with engineering backgrounds } \\
\text { indicated that a strong technological posi- } \\
\text { tion was an Important necessary condition } \\
\text { for pursuing the actions proposed in part B. } \\
0 \% \text { of those with manufacturing and genera1 } \\
\text { business included this condition and } 12.5 \% \\
\text { of those with marketing backgrounds included } \\
\text { this assumption. In part A, al1 participants } \\
\text { with general business and other backgrounds } \\
\text { added this condition to the } 1 \text { ist of conditions } \\
\text { specified and } 7.1 \% \text { of those with engineering } \\
\text { backgrounds and } 6 \% \text { of those with marketing } \\
\text { backgrounds added this assumption. }\end{array}$ \\
\hline V14 & .10 & .15 & $\begin{array}{l}25 \% \text { of those with marketing backgrounds in- } \\
\text { cluded this condition that product quality be } \\
\text { a business strength. } 0 \% \text { of those in other } \\
\text { groups included this condition in part } B \text {. }\end{array}$ \\
\hline $\mathrm{V} 17$ & .04 & .32 & $\begin{array}{l}42.8 \% \text { of those with an engineering background } \\
\text { specified high contribution as a condition } \\
\text { required for pursuing the actions proposed in } \\
\text { part B. } 57.1 \% \text { of those with manufacturing } \\
\text { backgrounds and } 50 \% \text { of those with marketing } \\
\text { backgrounds included this condition. This } \\
\text { variable probably appears as significant } \\
\text { because } 14.3 \% \text { of those with engineering back- } \\
\text { grounds also added this condition in part A } \\
\text { while } 0 \% \text { of the other groups did. }\end{array}$ \\
\hline
\end{tabular}

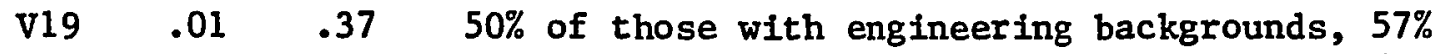
of those with manufacturing backgrounds, and $68.8 \%$ of those with marketing backgrounds suggested increasing marketing efforts in response to conditions 1isted in part $A$.

V20 $\quad .05 \quad .36 \quad 0 \%$ of those with marketing backgrounds suggested vertical integration (forward) as a response to conditions described in part A. $42.8 \%$ of those with manufacturing backgrounds and $7.1 \%$ of those with engineering backgrounds suggested this approach. 
TABLE XVII

SUMMARY OF CONTENT VARIABLES SIGNIFICANTLY RELATED WITH MANAGEMENT LEVEL

\begin{tabular}{|c|c|c|c|}
\hline \multirow[b]{2}{*}{ NAME } & \multicolumn{2}{|l|}{2} & \multirow[b]{2}{*}{ DISCUSSION } \\
\hline & $x$ & V & \\
\hline v26 & .05 & .25 & $\begin{array}{l}40 \% \text { of those in other than general or } \\
\text { functional management suggested revising } \\
\text { market structure as a response to conditions } \\
\text { in part } A . \quad 11.1 \% \text { of those in general manage- } \\
\text { ment and } 8.3 \% \text { of those in functional manage- } \\
\text { ment positions suggested this approach. }\end{array}$ \\
\hline v27 & .03 & .26 & $\begin{array}{l}22.2 \% \text { of those in general management positions } \\
\text { said that the approach proposed in part B } \\
\text { couldn't work under any conditions. One of } \\
\text { nine in general management positions said } \\
\text { that conditions in part A could not allow any } \\
\text { action proposals to be successful. Only one } \\
\text { participant in functional or other management } \\
\text { categories suggested that conditions in part A } \\
\text { could not allow a successful action plan. }\end{array}$ \\
\hline
\end{tabular}


which reflected their professional training and experience. Responses tended either to deal with support needed for their particular area (i.e., marketing approach to increase marketing effort or engineers' concern for technological position) or with activities they can do little to control (i.e., marlseting concern for product quality anci manufacturing concern for sales).

Variations in individual responses from the model may have sone inplications for the variation in actual plan content frow the expected content nodel as discussed in "Goodness of Fit Test" (p.65). Technological position (v8) appeared as more significantly associated with action variables than the model predicted. The strong concern for v8 along those with more experience and anons those with eneineering backiground may explain the significant association of vo with other variables in the formil plans.

\section{Sirilarity Amore lianajers}

Sinilarity coefficients for condition variables are based on the results of part A of the questionnaire. Similarity coefficients for action variables are based on the results of part $B$.

Table XVIII (p.93)sumarizes the results of agreenent score calculations for subgroups of managers for both parts $A$ anci $B$. Agreewent scores are not adjusted for average variable frequency and are not comparable to previous agreement scores.

These results suggest that organizational constraints do impact strategic logic. Agreement among those with longer length of service was higher than any other subgroup. On the other hand, management level seemed to make little difference to agreement although those at the 
TABLE XVIII

RESULTS OF SIMILARITY COEFFICIENT CALCULATIONS FOR SUB-GROUPS OF MANAGERS

NAME

V35 LENGTH OF SERVICE

less than 8 years

8 - 15 years

more than 15 years

V36 PROFESSIONAL GROUP

engineering

manufacturing

marketing

V37 MANAGEMENT LEVEL

general

functional

other
RESPONSES

PART A

.080

.086

.120

.101

.096

.108

.089

.098

.078
RESPONSES

PART B

.046

.101

.071

.068

.066

.068

.066

.063

.132 
"other" level agreed less with each other in part $A$ and wuch more with each other in part $B$. This sufgests that if there is an apprentice program in strategic lofic, it is associated with corporate service lenth rather than managerient position. The association of similarity with service lengtr suggests $a$ more informal, possibly more subjectively-based apprenticeship progran than sirilarity associated with management level would suggest.

Siwilarity of perspective within functional groups was confirned for those witin marieting and engineerine backcouncis. Hanagers with warketing backgrounos appeared to agree with each other nore than other Eroups. This way be because marketing-trained nanagers have had more experience with exercises such as this one.

The largest differences in siuilarity coefficents lie betiven agreement on part $A$ and agreenent on part $B$. This way be because scores were not adjusted for average frequency. Results in part $B$ were not consistent with the expected content nodel or any rodifications to the model. The highest agreenent was anons those who are at sove manacenent level other than Eeneral or functional manajers. The second highest was anone those with mediui. leneth of service. This result is similar to findings in "Plannine Exercise: Plannin̈̈ Process" (p. 79) whici: identified little pattern to the response frequencies in Part $B$. Although this may be due to the inadequacy of the questionnaire, the process which relies on evaluation of current activities as the key planning process appears ineffective. 
SUIAIARY

This chapter described the results of the effort to compare actial strategic plan content with expected content; the results of furtier analysis aimed at developine a nore complete nodel of plan content; and the effectiveness of several tests for acilieving these results. Four of 17 expected pairs vere present, and four additional unexpected pairs appeared. Similarity coefíicient analysis showed that in Fast Delta Corporation plans, content results of the planrine process diu not depend on the inclusion of particular prenise variables. Sivilar analysis ôे business stratery case studies shored trat content was incin iwore depencient on the inclusion of particular prenise variabies. Factor analysis identified clusters of content variables wici: appear to characterize strateric content for tie conpany as a viole. Tile wajor factor or cluster explains $45 \%$ of the variance and includes a lario nurber of variables. Several variables load heavily on hore than one factor. Several content variables appear associated vith forecasts in a lofical way. Plan content was not associated with past perforrance, altrough several content variables were associated vitin the year tive plan was written. Results of wanager interviews showed planning reslits similar to both expected and formal plar content when tiae noriative planning process was used. Particular content variables vere significantly associated with each of the nine subgroups of managers. lore content variables were more closely associated with lengtin of service and functional background than vith managenent level. These results were confirmed by the results of sirilarity coefficient analysis of manager responses. Ilichest agreenent on strategy was anong those 
with longest length of service. 


\section{CHAPTER V}

SUHARY, CORCLUSIONS AHD RECOIIIEIDETIOHS

\section{SUIAIARY}

The intent of this study was to evaluate the content of Fast lielta Corporation business plans afeainst an expected content lodel, develop a wodified nodel based on the comparison of expected with actual plan content, and develop alterrative methods for evaluating plan content based on this modified nodel.

A goodness of fit test was used to neasure actual plan contert against the expected content model. Alternative explanations for plan content were sought by ezarining plan content for patterus other tlan those predicted by the expected content wodel, and by exaninino several objections to the expected content sodel.

\section{Patter: of Stratejic Loric}

Study nethod exanined actual plan content for 17 variable pairs. of the 17 expected pairs, the soodness of fit test identified four pairs as actially occurring in Fast Delta Corporation plans. Low frequency of sowe variables prevented testing for about one-third of the expected variable pairs. Coding limitations meant that the absence of trese 13 significant pairs was difficult to interpret. Four additional pairs of variables appeared as significant. Each additional pair can be rationalized within the context of the Fast Delta Corporation planrino 
system.

Similarity coefficients for condition sets were higher when plans agreed on the presence of actions. The presence of an action appears associated with a consistent set of condition assumptions. The similarity of action sets for a particular condition does not show suci a consistent pattern. High market share (v1), profit objective (v $\sigma$ ), and market share growth objective (v7) do not appear as signiricant determinants of action plans in this test while the expected content model suggests that they should be amone the nost sienificant variables. The presence of a particular condition does not seen to inply a consistent action package.

Factor analysis identified plan content factors whicis were broader than simple pairs of actions and conditions. This analysis produced several interesting results:

1) Action variables loaded heavily on separate factors wilie condition variables, particularly those relatine to objectives, loaded on several factors. In this population, action variables are rore predictive of condition sets. The condition variables are not simple variables but contain nore complex strategic implications.

2) All factors included heavy loadings by more than simple pairs of variables. This suggests that strategic factors are quite covplex. These complex factors appear to describe types of businesses rather than marketplace laws.

3) One very heavily loaded factor accounts for more than 45\% of the variance. This suggests that business strategy or strategic logic comnunicated through the plans is relatively howoseneous altinough 
complex.

\section{Role of Current Activities}

The strong relationship between plan year and profit objective (v6), product quality (v14), and action to increase parketine/sales efforts (v19) when these variables appeared unrelated to other content variables suggests that annual changes in corporate-vicie policy or perspective affected these variables. There was only one content variable related to past perfornance. The strong associations between content variables and perforuance forecasts support tive notion that forecasts provide a synthesis of the impact of a variety of action plans and conditions. The content-forecast associations shoved regular patterrs which could be explained in expected content nodel teris.

The results of the plamning exercise in part $A$ or the questionnaire are sinilar to the results of the strategic plan analysis. llanagers appeared botr: nore successful and wore familiar witin a plannine process winich begins with the analysis of conditions. Despite tie simple loadine of action variables on stratejic factors, manä̈ers appear to rely heavily on the recommended strate gic planning process froli tie Corporate Strategic Plannine lanual (1977) in developinê business plans. There is no support for the idea that the planning process explicitly begins with a coimitment to and focus on current activities.

\section{Organizational Inpacts on Plan Content}

Analysis of similarity coeficients for case studies identified key variables which were predicted by the expected content model. These results confirm the validity of both similarity coefficient 
analysis and the expected content model.

The comparison of similarity coefficients under agreenent and disagreement between business plans and case studies showed that tire Corporation plans were considerably more similar to each other than those of other companies were similar to each other. Business plans from The Corporation showed more similarity arong both condition and action sets even when they disagreed on the presence of the premise variables. Some variables are consistently included in the fortal plans whether or not the logic represented in the expected content nodel supports the inclusion of these actions and conditions.

Analysis of significant variables associated with manaiger backiground showed content variables associated with length of service and functional background. These results offer sone insight into forulal plan content analysis results. The significant association of strons technical position ( $(8)$ with the responses of wanagers with the longest length of service and of managers with engineering training suögests 2 possible explanation for the unexpected appearance of $v 8$ as a significant variable in formal plans. These managers probably have a strong voice in strateßic business plan development.

Similarity coefficient analysis of manager responses supported the notion that a company perspective is characteristic of managers' strategic thinking. Similarity was highest anong those with the Iongest length of service. Similarity was also high among those with similar functional training, although not as high. Surprisingly, the responses of managers at higher managenent levels were no more similar than those at lower levels. Similarity analysis results for part $B$ of the 
questionnaire support the conclusions above: the process required in part $B$ was clunsy and difficult for participants. Results showed very little pattern.

\section{CONCLUSIOHS}

Conclusions based on these results relate to the triree-part intent of this study:

1) to compare a model of expected plan content with actusi tusiness plan content developed in the study firt:

2) to develop a modified mociel of formal plan content which recognizes organizational influences on plan content.

3) to suggest a method for evaluatinë business plan content desed on this modified model.

Coruparison of Actual with Expected Plan Content

The results of several tests allow the conclusion that the mociel concept is basically correct but inconplete. At Fast Delta Corporatica, managers' planning löic is based on the analysis of conditions, the developrent of a condition set, and tile relation of these conditions with an action set. The plannine process recomencied bj the forwal systen appears to be used even in informal exercises. The condition variables have more couplex strategic implications which suwests that this process is not simple. The absence of sowe variable pairs and the presence of others as well as the failure of the similarity coefficiert test to distinguish significant variables must be explained throush the use of a modified nodel. 


\section{Development of a Modified Model of Plan centent}

Plan content as evaluated by this method appears based on additional planning principles besides the general principles in the expected content model. These principles are characteristic of the corporation as a whole. These additional principles can be further identified as based on:

1) short-terii concerns, that is, plan content characteristic of the company in a particular year;

2) logical concerns, that is, plan content characteristic of a class of companies sinilar to the particular company;

3) historical or cultural concerns, that is, plan content characteristic of the company in the sense of "unique to the company."

Figure $10(p 102)$ shows a modified version of the normative model which includes these additional dimensions. Each of these is discussed below.

Short-Term Corporate Concerns. Although the five-year piannin: window used in Fast Delta Corporation business plannine suesests a longer perspective, this study showed that sienificant short-term conditions and issues are recognized in formal plans.

of those content variables significantly related to plan year, some are integrated into the formal plan using the general plan logic of the expected content model. Others, for exarale, increase profit objective (v6), and appear associated with plan year but not to other content variables. These variables are not integrated logically into plan content.

Inclusion of short-term and locally arbitrary issues in business 


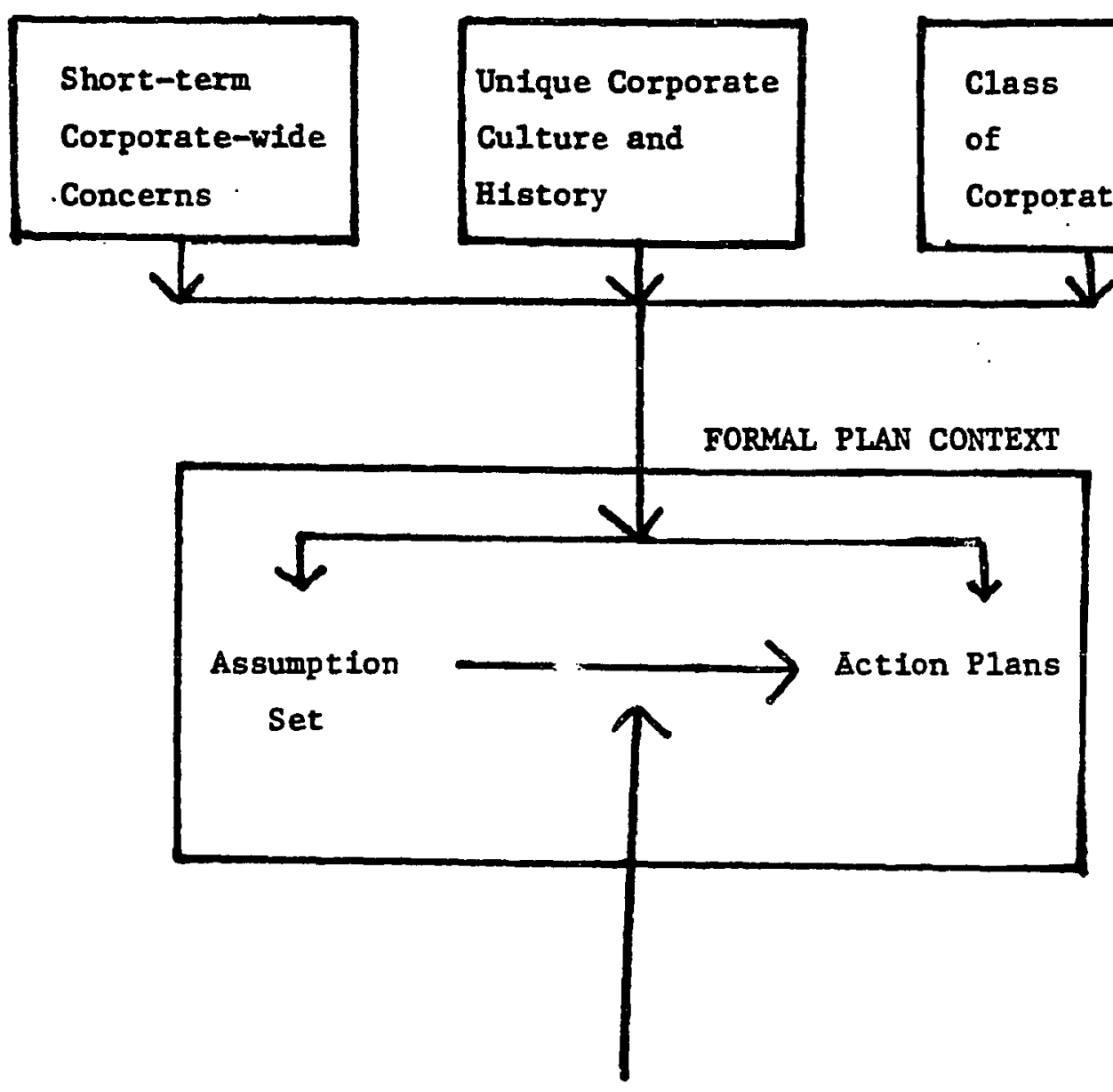

Marketplace Laws

Figure 10. Modified Model of Formal Business Plan Content. This model 11lustrates the impact of three other types of factors from outside the formal plan context. These factors include short-term corporate-wide concerns, unique aspects of corporate history and cuiture, and corporate characterlstics which are those of a class of companies such as companies at a particular IIfe-cycle stage, companies in a particular industiy, etc. These factors appear to Impact plan content independently, in some cases, of the logic of marketplace laws which relate an assumption set and proposed action plans. 
plans is not, counter to the intent of the strategic planning process. Strategic concerns appropriate for business plans are not necessarily long-term. The busiress planning process serves as an effective comunication process for disseminating any general corporate concern. Content variables related to plan year only may be imnediate concerns imposed by top managewent. Corporate directives also provide one way of unifying and integrating otherwise divergent business plans. The degree to which these are integrated into the logic of an individual business plan may depend on the planning skill of midole managenent.

In general, corporate-wide issues which gust be included but which cannot be integrated inwediately into lons terw logic will modify the logical contents of formal plans as measured by these evaluation methods. It is expected that the more the business plannine exercise is used as a decision-making tool rather than simply a wanagement developsent exercise, the more pressure to incorporate short-ter.. corporate-wide factors into the logic of plans.

Lofical Concerns Chacacteristic of a chass of Corporations. Corporations can be classified in various ways. Discussion belo: focusses on the following alternative classifications: industry type (such as SIC code used by the U.S. Department of Comerce), wariset or industry life cycle stage (Hofer 1975), corporate life cycle stage (Greiner 1972), and corporate structural type (for exanple, dezree of centralization) (Chandler 1964).

The particular integrative intent of the formal process suegests that the business plans of all companies which rely on top-down as well as bottom-up communication will be impacted by the short-tera corporate 
concerns discussed above. The extent to which planning direction is top-down and the extent to which business planning is coupled to the annual budgeting processes may determine the impact of short-tera. concerns. The planning skili and experience of a particular company may determine the extent to which these concerns are incorporated into longer-term, local plan logic.

The above results suggested that a surprisingly homogeneous strategic approach was characteristic of this company. While the company's characteristic strategic factors identified through factor analysis may be unique to the company, the principle of meisurin: corporate diversity or honogeneity in this way is established. Sozie relative degree of homogeneity may be characteristic of companies at different life cycle stäes. This company established a decentralized structure relatively recently. If this concept is valid, this approach might be used to track the increasing diversity of this or any other company with a decentralization policy.

The processes suggested above for corporate integration or maintenance of homogeneity may also be characteristic of a particular class of corporations. The identification of strategic training as informal and long-term suggests a matrix of alternative approaches to developing managers' strategic 10gic. (See Figure 11, p.106) This matrix may suggest asscciated corporation types which rely on these training approaches. The training program in this recently decentralized, relatively young company appears inforwal and corporate-oriented. A more mature and lifinly diversified company may rely on a business-oriented, formal training program. The tests used 
TRAINING STYLE

BORYAI INFORMAL

A

I

N

I

$\mathbf{N}$

G

CORPORATE-

centralized

companies.

structured

path within

the organi-

zation.

centrailzed

companies.

no structured

promotion

path within

the organi-

zation.

R

I

E

N

BUSINESS-

decentralized

decentralized

companies.

structured

companies.

ORIENTED

promotion

path within

no structured

promotion

path within

the organi-

the organ1-

zation.

zation.

F1gure 11. Matrix of Alternative Approaches to Strategic Logic Training Program. The results of this study suggested the above typology of management development approaches to strategic planning. The Corporation was shown to have used an Informal, corporate-oriented approach. 
here could distinguish the results of these two approaches. In the hypothesized company, siuilarity would be highest among managers at the highest management level. The formal plans in such a company would shor: a relative difference pattern for similarity coefficients under afreement and disacreenent nore similar to that of tile case stuciy population.

The unexpected appearance of significant variables relating to technolorical position and mariet characteristics nay be characteristic of strategic thinling for corporations within this particular inoistry. Tiue significance of these variables amone case studies, over half of which were frow the electronics industry, confirrs tinis.

The close integration of the Gronti objective with nearly all strategic factors is more difficult to classify. The significance of this objective may be characteristic of the class of all electronics coupanies, of all conpanies in relatively fast growinö warliets, of all conpanies at a particular life cycle stage, or of industry in general.

The role of certain professional groups in planning maj also be characteristic of an industry-based class of companies. The significant relationship between key variables and managers with engineering training is probably characteristic of the electronics and other bigh technolosy industries. This relationship nay also be characteristic of companies in this life cycle stage. The extent to which operational product or engineering concerns dowinate financial or more general concerns may diminish as this industry matures and as individual companies grow, mature, and diversify.

These conclusions are not inconsistent with the results of other 
research (Schoeffler et al 1974, Hofer 1975, Chandler 1964) which relates strategy and company structure. Previous work does, however, discount the significance of industry type and tends to emphasize the market structure of the particliar business a company is in ratiner tran the general maiket environment of the company as a whole.

Historical or Cultural Concerrs Unioue to a Particlilar
Organization. The results of this study suggest that an origanization imposes constraints on strategic thining. If this were not true, plars for a sinfle company would sho: the same sinilarity coefficient pattern as case studies and the variance explained by factor analysis woula be more evenly spread over the factors identifiec.

The similarity of incivioual manajers' responses to plan content sugbests that degree of howogeneity is a reflection of corporate cultire and history. This analysis suggests a mechanisi whereby corporate stratefic logic rewains internally consistent and howozeneous despite the corporate intent to diversify. The siwilarity of responses aworio those with lonser lenEth of service rather than with higher managenent level suggests an infortal rather than a forwal training prograw. The inplied long-tern, experience-based and inforaal prozran Ior individuals' strategic development sugsests that corporate integration. through a common strategic perspective is not directly managed for in this company.

The study approach used here leaves key questions open about tile significance of plan content for identifying strategic logic. The logic behind a company's strategic plans may not be unique at all. Instead, the planners may share a unique company plannine language. Variables 
such as "strong technological position" and "high product quality" may carry unique company definitions. The list of unexpected key variable pairs in this corporation's plans may reflect more conventional lojic once planners define these terms.

Supplenental Evaluation Hethods for Stratejic Plans

This modified model requires that plan content be evaluated not only against the expected content model but against otrer expectations as well. The expected content model provides a generally recogrized standard for plan logic against which short-ters and unique corporate concerns can de balanced.

Clearly if short-teri, corporate-wide concerns were effectively being integrated into plan logic, these variables would be colpled with others as predicted by the expected content model. If top rianasers dio not use the business planning process for short terr concerns, there would be few variables associated with plan year. If top nanagers were attemptinê over the years to develop a more diverse stratefic approach, the variables should load stratefic factors differently with tive. This evaluation method allows a neasure of the injact of strateric thinisine which is not consistent with an expected content rodel. Once the relationship of actual content to this expected content is established, managers and staff can asle which short-ters and unique corporate concerns should dominate Eeneral logic. This evaluation technique allows staff to pinpoint which logic is inconsistont. and possibly which groups share this logic. This helps identify which procedures should be changed, which training programs for which audiences must be implemented, and which top mariagenent leadership 
efforts have been successful in changing widdle management stratejic attitudes.

Techniques from this exploratory effort which appear viable in evaluating these expectations include: the identification of significant variable pairs, the identification of strategic factors, the characterization of corporate hosozeneity relative to the diversity reflected in case studies, and the comparison of manager planning loilc with unique aspects of corporate strategy.

\section{RECOIIIEIDATIOIS}

Recormenciations are aired at the several major auciences identified in the introductory section: top nanarewent, wicide management, corporate planning staff, and those doinf further researcis in strateaic planning. Recomendations are based not only on the specific findings of this study of a single firi, but on the exploratory nature of this study. Because this study is exploratory, recomendations emphasize opportunities for further study and the value of plan evaluation methods which address these additional dinensions of plannins.

Top lanazement

Current "new planning" models place top managers in the role of "ringmasters" or portfolio managers attempting to integrate and balance a number of diverse businesses. A recent Business Heek article (Decenber 18, 1978, 62) highlighted top management's need for tools which would change this role frow a passive balancing act to a more pusitive leadership role. 
Developing a moré positive leadership role may require developing a more global strategic perspective which is more that the sum of the separate business strategies. Current tools for integratine business plans (for example, the "spot and dot" chart (Boston Consultine Group 1974)) which depend on the portfolio management nodel of the top management function are inadequate in at least three ways:

1) Tools based on the portfolio managewent model are often inappropriate for the majority of companies which are not coupletely decentralized and diversified. For exauple, the portfolio model assuries that poorly financially perforwing businesses can be divested without impacting other businesses. This is often not the case in a confany which is only partially decentralized.

2) These tools are useful only for addressinit financial integration. Other resources incluoing tive, people, experience, tectnology, market inage, and warket position are acidressed indirectly if at all. These are often the nost difficult resources to use or develop synergistically.

3) These methods are based on data which are often unavailable, inaccurate, or biased in favor of a politically correct ansier or wishful thinking. It is impossible within the context of tizese tools to evaluate the validity of the assumptions behind the figures since the figures are presented as facts, and the assumptions are not presented at all.

The proposed evaluation model addresses these problens: it assumes that the study company is not completely decentralized; it addresses non-financial issues; and it depends on infornation about 
attiludes, not financial forecast data. Because the proposed evaluation model allows the measurement of additional dimensions of corporate position, it provides a supplenent to the above types of analysis.

By trying to pinpoint the ways in which plan content and logic produced by middle managers do not meet expectations, a picture of current management strategic perspective can be established. To the extent that this perspective represents top wanagewent perspective, these results can be used in evaluating current corporate business definitions and nei business opportunities. To the extent that this perspective is not coincident with top managenent perspective; these results identify opportunities for top wanagenent leadersiip.

\section{Liidile lianazienent}

This modified evaluation model sugbests three dinensions for evaluating plans in addition to the expected content model. These sugsest a new perspective for the evaluation of the short- and lon:-tert: viability of a particular business. This is, of course, inportant at the top management level, but it is also important at the midile management level for career planning and for establishing resource expectations. These dimensions help explain top manageuent decisions to support some businesses while divesting others counter to the recoumendations of conventional financial analysis.

The classification of plan content into that required by General business planning practices, that required for short-tern corporate reasons, and that required for corporate or industry cultural reasons is an aid in sorting and balancing plan assuruptions and logic which may seem contradictory. This classification schewe for plan content 
provides an aid for the individual manager in the developnent of his own stratesic logic model.

The analysis of managers' planning lofic nay be particularly useful to middle management in career planning. This analysis sugsestei that with length of service in a particular company, nanagers developed more similar strategic logic. This more local planning perspective, while useful in the quick solution of furctional problems, may waise tine search for alternative strategies nore difficult for those with longer . length of service.

The strategic plannine effort at the division or business unit level is parallel to, if more constrained than, the process required to develop a corporate definition. Plans developed at this level directly reflect the strategic perspective of the business manajement tear. This study confirus that at least some functional concerns iupact business strategy. General managers are faced with the tasis of assembling a tean for strategy forkiulation which reflects the desired level of homogeneity or diversity of perspective. This is particliarly important in the wany stratesic situations where accurate data are unavailable.

\section{Corporate Plannine Staff}

Corporate staff often attempt to apply general planring logic such as the expected content model in evaluating business plans. Staff are often frustrated when their comments are ifnored or dismissed with: "We're different. Those rules don't apply to us." Frustration mounts because managers often can't state explicitly which rules do apply. This method helps identify explicitly the ways in which nanagers feel 
their company does not need to conforri to general business ruies. Logic based on these unstated rules which is potentially out-of-date or internally contradictory can be examined more carefully. The valio strategic relations can be incorporated into the staff's expected content model of expectations.

The results and conclusions of this study sugeest that ti:is evaluation approach is viable and provides sone additional informetion about corporate stratesy which is not available through other netiods. The techniques for analyzing plan content are simple with the aid of the stanaard SPSS package. (liie et al, 1974)

The experience with this study subgests sone podifications in the evaluation process:

1) It was difficult to draw conclusions about the plan process frow the plan content. The planning process appears as a coiplex iterative process with no single one-way löic detectable. Part 5 of this questionnaire was rot useful.

2) Content variables should be chosen relative to corporate concerns and expectations for what variable linirages should be included in forwal plans. The expected content codel shown in Table I (F. 7 ) represents a first cut at a generally acceptable maciel for industrial products manufacturers in a high technology warket. Other expected significant variables and linkages may be nore relevant to other companies and industries.

3) The results of this technique should be evaluated against a specific set of expectations. In this study, the expected content model provided that set of expectations. Once plan content has been 
evaluated, these results provide a benchmarl or a new set of expectations against which later evaluation reslilts can be compared.

\section{For Further study}

Topics for further study based on this researci include:

Specific Variables. This study raised several questions about tre complex nature of key condition variables. It is not clear wisether the particular variables chosen were not defined closely enouibl or whether these coinion strateüic planning concepts are really more complex tian supposed. For exanple, when hich market frowth rate (v1) loads heavily on two major factors, is this because one factor is describing a Erouth rate of $25 \%$ and the other a Erowth rate of $35 \%$ ? Or is this because any market growth rate assuruption poses conplex questions for business strategists?

\section{Explicitness of Planning. This study was distinctly linited by} the evaluation method which identified positive correlations and positive matcies only. This approach meant that the whole topic of "generally understood and accepted but not explicitly stated" strateg̈ic lofic could not be directly addressed. If content variables hed been evaluated as either absent, false, or present, (instead of just present), plan evaluation may have revealed a richer pattern of strategic logic.

Classes of Organization and Strategy. This study provides little direct evidence which allows the distinction anong strategic 10jic characteristics of different classes of company. It is unclear whether the relationship between growth and profit objectives is characteristic of all electronics companies, all companies in growing narliets, or all 
companies. Comparative studies of other companies using this method would aliow wore definite conclusions.

Planninz Process and Stratery. Despite the necessary conclusion about the validity and widespread use of the normative plannine process, the issues raised by Sahal (1976) about the process of organization adaptation are sisnificant. A deeper case study of a particular planning effort may address the question of the extent to which organizations choose their environrents rather than adaptine to environmental pressures. Study techniques such as direct decision observation are required in orcier to exanine these issues.

Optimuri Corporate Streteric Perspective. While a measure of corporate homogeneity of perspective was established through factor analysis and similarity coefficient exercises, this study has offered little guidance to managers or staff in recomending an optiwuri wix of stratefic factors or plan sirilarity. Additional studies comparine: these results with results of other companies would be necessary to identify the relationship between these characteristics and other company characteristics such as size, sales, and asset levels.

Stratesic Plannine Training The matrix illustratins alternative approaches to strategic planning training (Figure 11, p.107)sugsests ideas about strategic perspective development which might be tested in a comparative study of large corporations. Results of such a study way suggest which of the three approaches discussed in Chapter II (p.37) for developing corporate "coherence" (Sarrazin 1977) is most effective under which conditions. 
REFERENCES CITED

Allison, Graham T. 1971. Essence of Decision, Boston, Little, Brown \& Co.

Ansoff, H. Igor 1965. Corporate Strategy, New York, Penguin.

Ansoff, H. Igor 1969. "Toward a Strategic Theory of the Firm," in H. Igor Ansoff, ed. Business Strategy, Penguin, Baltimore, 1969.

Ansoff, H. Igor and John Stewart 1967. "Strategies for a Technology Based Business", Harvard Business Beyiew, 45(6), 71-83.

Boston Consulting Group, Inc. 1974. (untitled slide presentation on concepts for evaluating business strategy), (unpublished).

Cannon, J. T. 1968. Business Strategy and Policy, San Francisco, Harcourt, Brace and World.

Chandler, A. D. 1964. Strategy and Structure, Cambridge, MA, The M. I. T. Press.

Clarkson, G. P. E. 1962. Portfolio Selection: A Simulation of Irust Investment, Englewood Cliffs, NJ, Prentice Hall.

Cooper, R. G. 1979. "The Dimensions of Industrial New Product Success and Fallure," Journal of Marketing, 43(Summer), 93-103. Corporation.

Cyert, R. M. and J. G. March 1963. A Behavioral Theory of the Firm, Englewood Cliffs, NJ, Prentice Hall.

Cyert, R. M. et al 1956. "Observation of A Business Decision," Journal of Business, $29(4), 237-248$.

Drucker, Peter F. 1973. Management, New York, Harper and Row.

Emshoff, James R. and Ian Mitroff 1978. "Improving the Effectiveness of Corporate Planning," Business Horizons, 21(5), 49-60.

Emshoff, James R. and Ian Mitroff 1979. "On Strategic AssumptionMaking: a Dialectical Approach to Policy and Planning," Academy of Management Revieu, 4(1), 1-12. 
1980. MForum 15: Division Managers Discuss Planning Process," Technology Report, Fast Delta Corporation, April, 3-23.

Gale,Brady 1977. "The Value of a Scientific Basis for Corporate Strategic planning," Strategic Planning Institute.

Gedrich, S. F. 1976. "Business Planning at Sperry Rand," Long Range Planning, 9(2), 38-49.

Greiner, Larry E. 1972. MEvolution and Revolution as Organizations Grow," Harvard Business Review, 50(4), 37-46.

Guth, W. D. 1976. "Toward a Social System Theory of Corporate Strategy," Journal of Business, 49(3), 374-388.

Hammermesh, R. G. et al 1978. "Strategies for Low Market Share Businesses," Harvard Business Review, 56(3), 95-102.

Hedley, Barry 1976. "A Fundamental Approach to Strategy Development," Long Range Planning, $9(6), 2-11$.

Hobbes, J. M. and D. F. Heany 1977. "Coupling Strategy to Operating Plans," Harvard Business Reviek, 55(3), 119-126.

Hofer, C. W. 1975. "Toward A Contingency Theory of Business Strategy," Academy of Management Journal, 18(4), 784-810.

Koontz, H. 1976. "Making Strategic Planning Work," Business Horizons, $19(2), \quad 37-47$.

Lawrence, Paul R. and J. W. Lorsch 1967. Organization and Environment: Managing Differentiation and Integration, Homewood, IL, Richard D. Irwin Co.

Levitt, T. 1965. "Exploit the Product Life Cycle," Hacvard Business Revier, 43(6), 81-94.

Leyshon, M. 1976. "Marketing Planning and Corporate Planning," Long Range Planning, 9(2), 29-37.

Mendenhall, W. 1975. Introduction to Probability and Statistics. North Scituate, MA, Duxbury Press.

Miller, Danny 1979. "Strategy, Structure and Environment: Context Influences upon Some Bivariate Associations," Journal of Management Studies, 16(3), 294-336.

Mintzberg, H. 1973. "Strategy Making in Three Modes," California Management Review, 16(2), 44-53.

Mintzberg, H. et al 1976. "The Structure of Unstructured Decision Processes," Administrative Sciences Quarterly, 21(2), 246-275. 
12/18/78. "The New Planning," Business Week, 62-66.

Newall, A., J. C. Shaw, and H. A. Simon 1958. "Elements of a Theory of Human Problem Solving," Psychological Review, 65, $151=166$.

Nie, Norman $H$. et al 1975. SPSS: Statistical Package for the Social Sciences. New York, Mc Graw Hill Book Co.

Paul, Ronald N., Neil B. Donavan, and James W. Taylor 1967. "The Reality Gap in Strategic Planning, "Harvard Business Review, 56(3), 124-130.

Quinn, James B. 1977. "Strategic Goals: Process and Politics,n Sloan Management Review, 19(1), 21-37.

Quinn, James B. 1978. "Strategic Changes: Logical Incrementalism," Sloan Management Review, 20(1), 7-21.

Rumelt, Richard 1979. "Evaluation of Strategy: Theory and Models," in D. E. Shendel and C. E. Hofer, eds., Strategic Management, Boston, Little and Brown Co., 196-244.

Rummel, R. J. 1976. Applied Factor Analysis, Evanston, IL, Northwestern University Press.

Sahal, D. 1976. "Homeorhetic Regulation and Structural Stability," Cybernetica 19(4), (preprint).

Sahal, D. unpublished. "Principles of Regulation and Control."

Sarrazin, J. 1977-78. "Decentralized Planning in a Large French Company: An Interpretive Study," International Studies of Management and Organization, 7(3-4), 35-59.

Schoeffler, Sidney, et al 1974. "Impact of Strategic Planning On Profit Ferformance," Harvard Business Review, 52(2), 137-144.

Schoeffler, Sidney, et al 1977-78. PIMS Letters \$1-\$10, Boston, Strategic Planning Institute.

Sokol, R. R. and Peter Sneath, 1963. Numerical Taxonomy, San Francisco, W. H. Freeman.

Steiner, George A. 1969. Top Management Planning, New York, MacMillan and Co.

1977. Strategic Planning Manual, Fast Delta Corporation.

Taylor, Bernard 1976. "Managing the Process of Corporate Development," Long Range Planning, 9(3), 81-99. 
Tilles, Seymour 1963. "How to Evaluate Corporate Strategy," Harvard Business Review, 41(4), 111-121.

Tilles, Seymour 1966. "Strategies for Allocating Funds," Haryard Business Review, 44(1), 72-80.

Thompson, James D. 1967. Organizations in Action, San Francisco, Me Graw Hill Co.

Vancil, R. F. 1976. "Strategy Formulation in Complex Organizations," Sloan Management Review, 17(2), 1-18.

Wilcox, J. W. 1972. A Method for Measuring Decision Assumptions, Cambridge, MA, The M. I. T. Press. 
A P P E D I C E S 


\section{APPEI!DICES}

APPEIEDIX

PAGE

A Glossary • • • • . . . • . • • 123

E Saz̃ple Plan and Codin- Illustration . . . 125

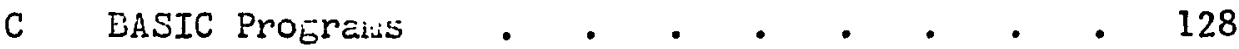

D Sarple Questionnaire and Codin'̈ Illustration . 140

E Case Study References and Coded Content Lata . 146 
APPEINDIY A

GLOSSARY

Teminology relatine to planning, especially business plannin ${ }_{i}$, is still not rigidly specific despite the nearly 25 years of plannine literature. Below are sone recent dejinitions and distinctions anon̈̈ teriss wizich vere used in this paper.

Eusiness (stratej) planning: typically strategic planninë at ti:e business level (see business unit). Toward goals set at the corporate level, business strateoy planning analyzes the strengths, wealnesses, threats, and opportunities in developing the stratejy for a firis's approach to a particular business. (Eusiness Veck Decenider 18, 1970, 62), (Hofer, 1975)

Business unit (or strateric business unit): "a unit or the coupany iitin its own mission and its own colpetitors and capable of developing an independent long tert: strategj". (Taylor, 1976) fi business unit way or way not be the sane as the unit used ror operating or adninistrative purposes. At Fast Delta Corporation stratëic business units are aduinistrative units for operating as well as strategic purposes.

Corporate (strateri) planninz: typically strategic plannnine at the corporate level (involving top manajecient or corporate officers). Toward the goal of unifying business lines and aiming them at a comon Eoal, corporate stratęic planning considers alternative investrent 
programs in its portfolio of businesses and the developient for acquisition) of new businesses. (Business Week Decenber 18, 1970, 62), (Hofer, 1975)

Entrepreneurial planning: "concerns itself witi creating the profit potential for the firn." (Ansoff 1978) That is, entrepreneurial planning deals with areas of opportunity such as new prociucts, nei: markets, etc. Ansoff includes stratejic planning as a type of entrepreneurial planning in that 1) the empiasis is on the searcin ror anci analysis of alternatives; and 2) forecasts and plans in stratejic planning are not necessarily extrapolative and assune discontinuities and change.

Lone ranje plannini: in long range planning, "the future is wade explicit througin environnental forecasts." (Ansorff, 197ó) lasec on a forecast, goals, action prograus, and budgets are set. Typically, lon; ranise planning does not include consideration of alternative futures or contingencies.

Strateric plannins: Typically a process for setting strategy which takes place on a periodic basis, focusses on a particular organization or set of organization, and deals witin products, wrirets, and technology. Stratejic planning includes consideration of organization strengths, weaknesses, threats, and opporturities vith the emphasis on analyzin ${ }_{\tilde{E}}$ alternatives. (Ansoff 1978), (Ansoff 1965)

Stratefy: "set of decision-making rules for Euidance of organization behavior." (Ansoff 1978) Typically strateäy includes a set of goals and major policies (Tilles 1963) and provides a "prinary source of cohesiveness " to an organization. (Vancil 1976) 
APPENDIX B

SAIPLE PLAIT AIN CODIYG ILLUSTRATIOH 
TABLE OF CONTENTS Page

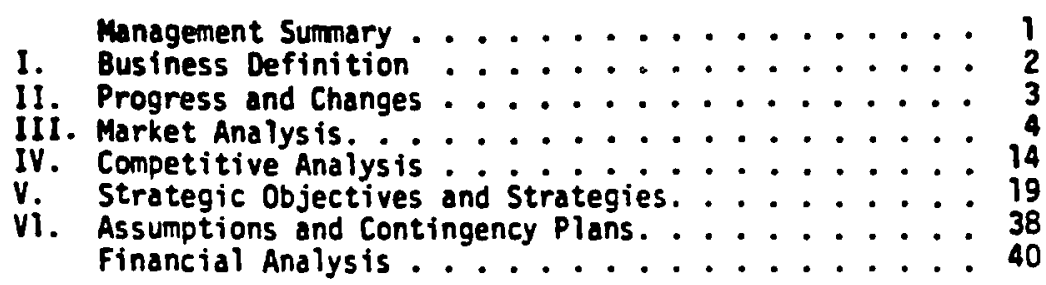

Management Summary

- Profitability Objectives: Increase income (after component allocations/ before taxes from 5 of net sales (FYCú) to Maintain current Income/Assets and Sales/Assets ratios.

- Growth Objectives: Grow orders at plan window.

In order to reach our growth objectives we intend to

- maintain our market position (Wx relative market share) in our current core businesses ( producers, distributors, equipment manufacturers and associated segments).

- establish a similar position with users in emerging

- segments.

- establish ourselves as the end users' preferred vendor of state-of-theart instruments in these segments; and, as the OEM's ( major supplier of components.

- Build on potential synergy between Products and other groups by working with to apply terinology outside the market and by marketing Products to the verticai Market.

In order to meet profitability objectives, we intend to

- maintain engineering and marketing cost of sales at current $\approx$ of net sales

- reduce manufacturing cost of sales from $\square$ of net sales to

- plan for business unit asset growth at slower than projected sales and income growth rates.

Market and Product/Market Strategies

industries will continue as our core market over the next five years. Due primarily to new distribution technologies

l. . Droducers and distributors are becoming larger portion of our potential market. (est. 35: market growth rate). We plan to address these markets

- by maintaining our traditional market strengths (strong field engineer and service force, a broad line of high quality, reliable products, active industry participation, and close high-level ties with sys tem and original equipment manufacturers);

- by extending these strengths to new markets within the $C$ industry.

technologies have opened the Industry to new equipment which corrects or enhances During rather than just testing, measuring and monitoring the buring
products which address this relatively new opportunity.

Sometime in the 5-10 year time frame, systems will become both economicaliy desirable and technically feasible. We expect that our work in processing and for today's markets will position us to enter these new application areas. 


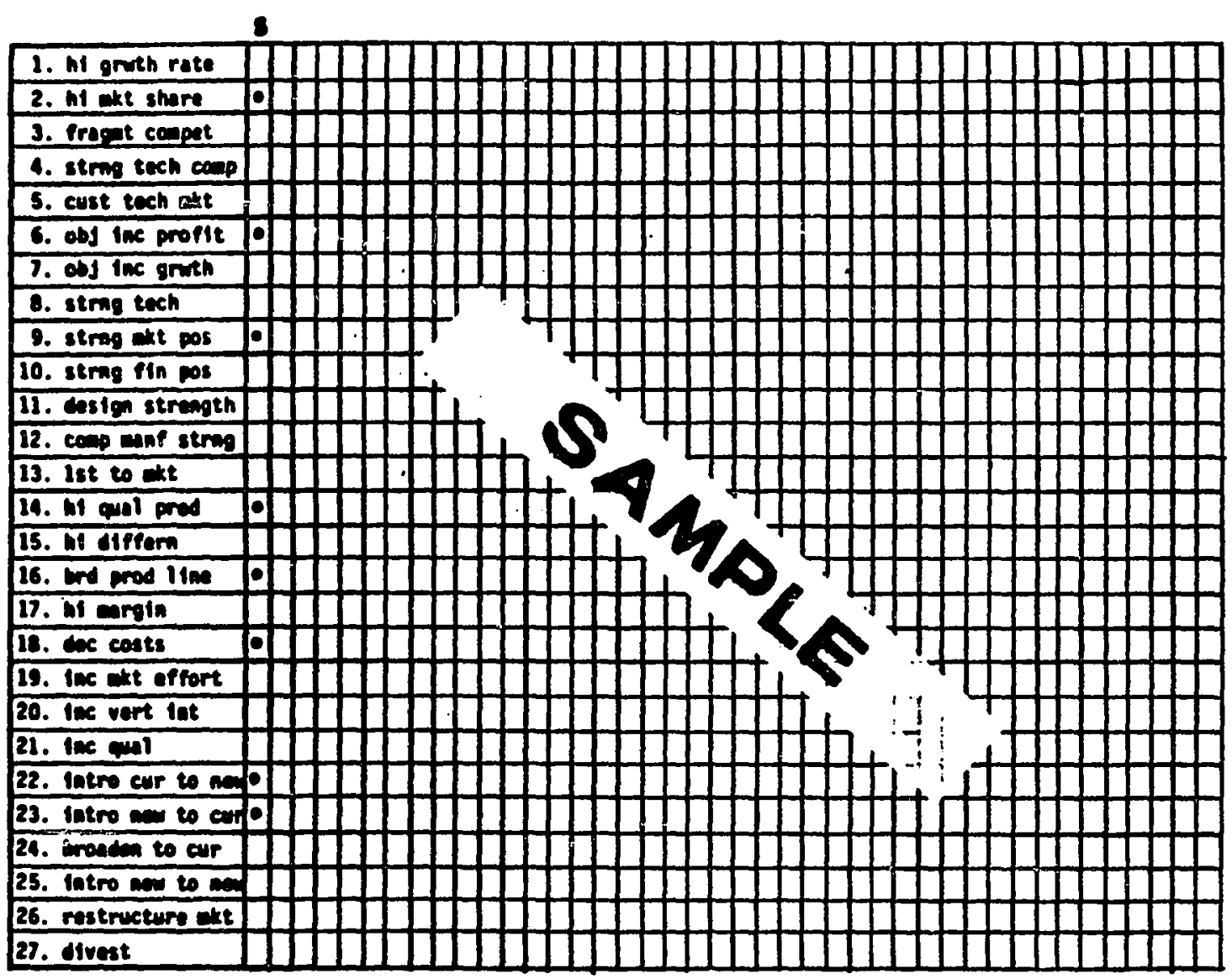


APPEIDIX C

BASIC PROGRAIS 


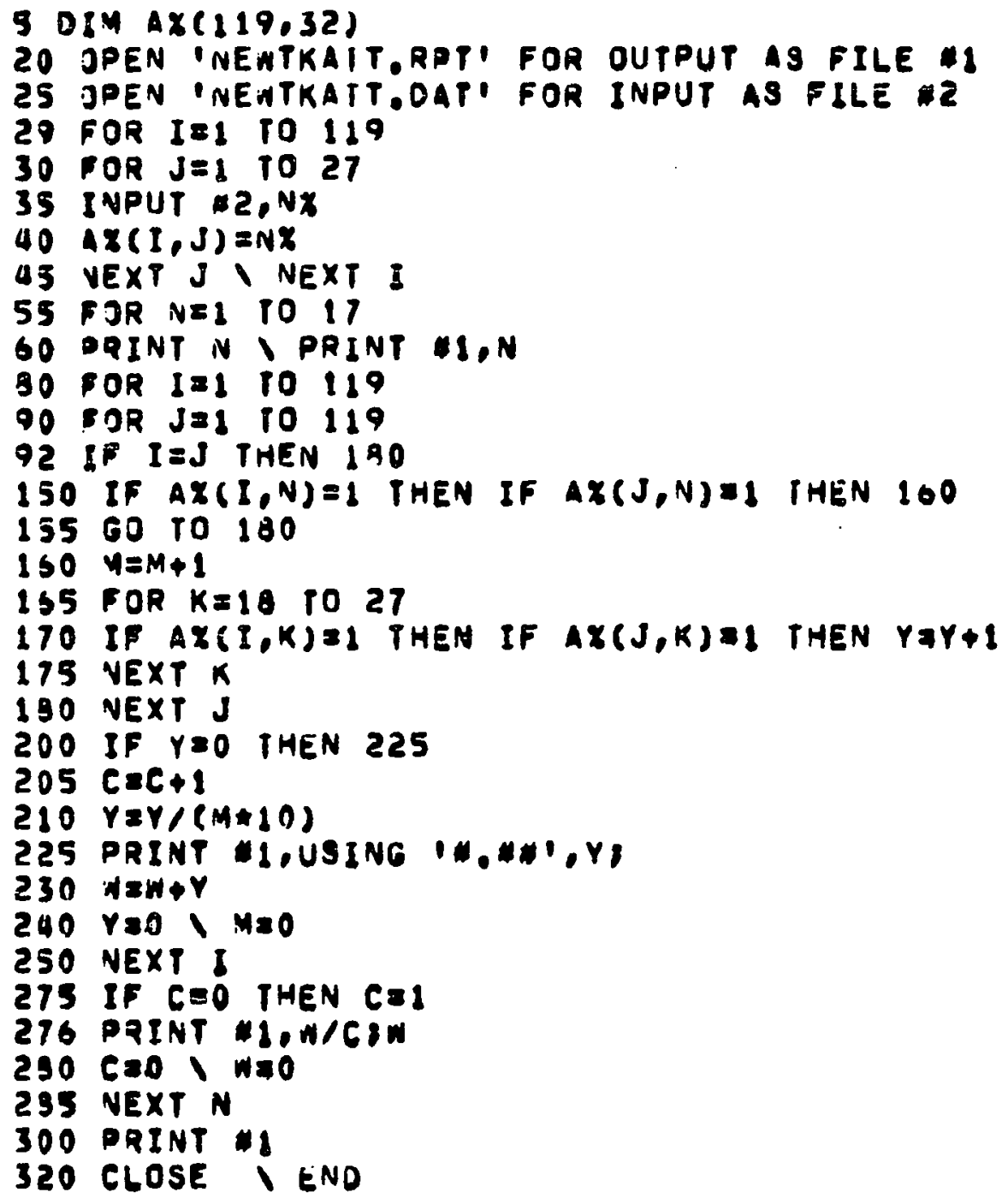




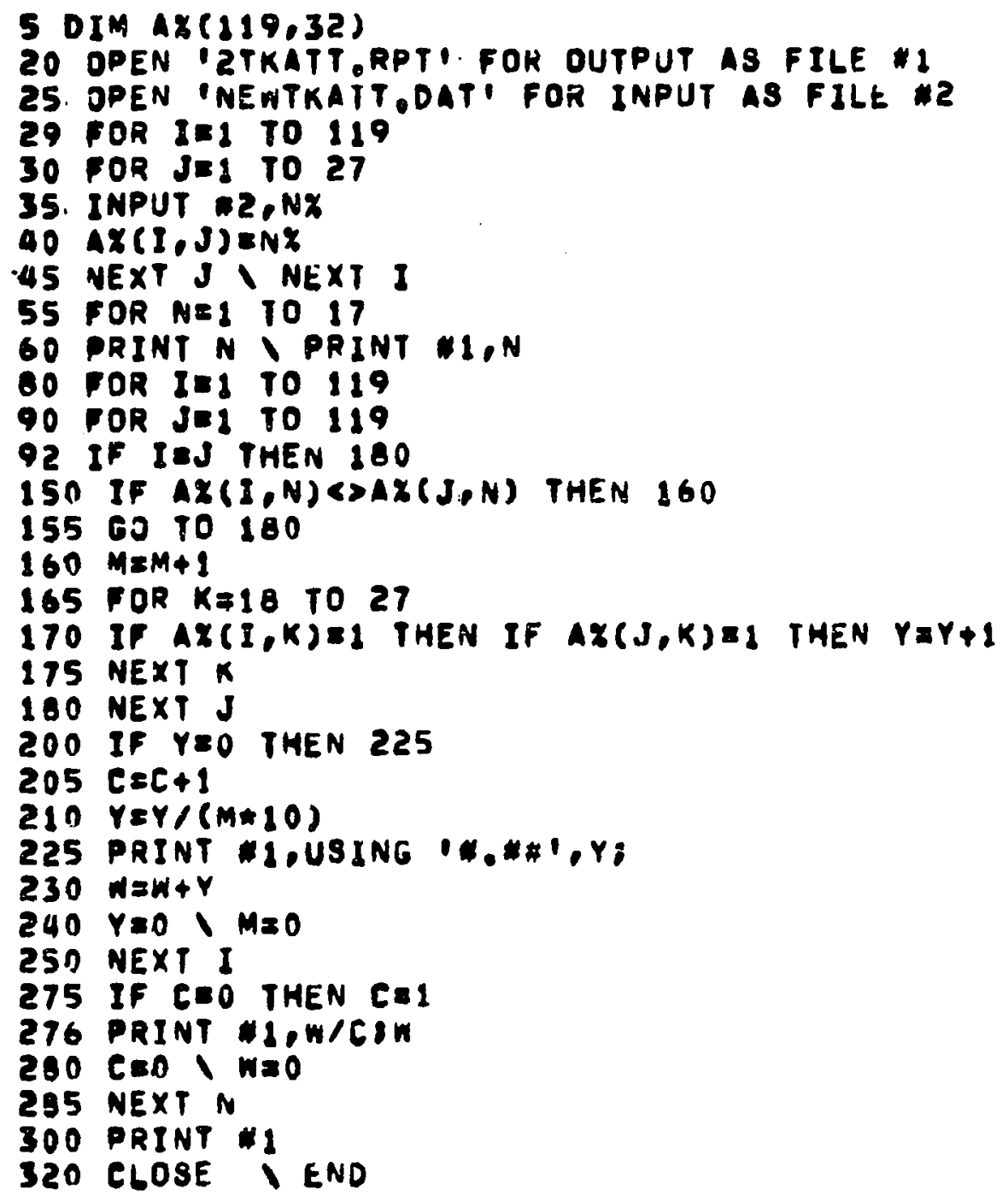




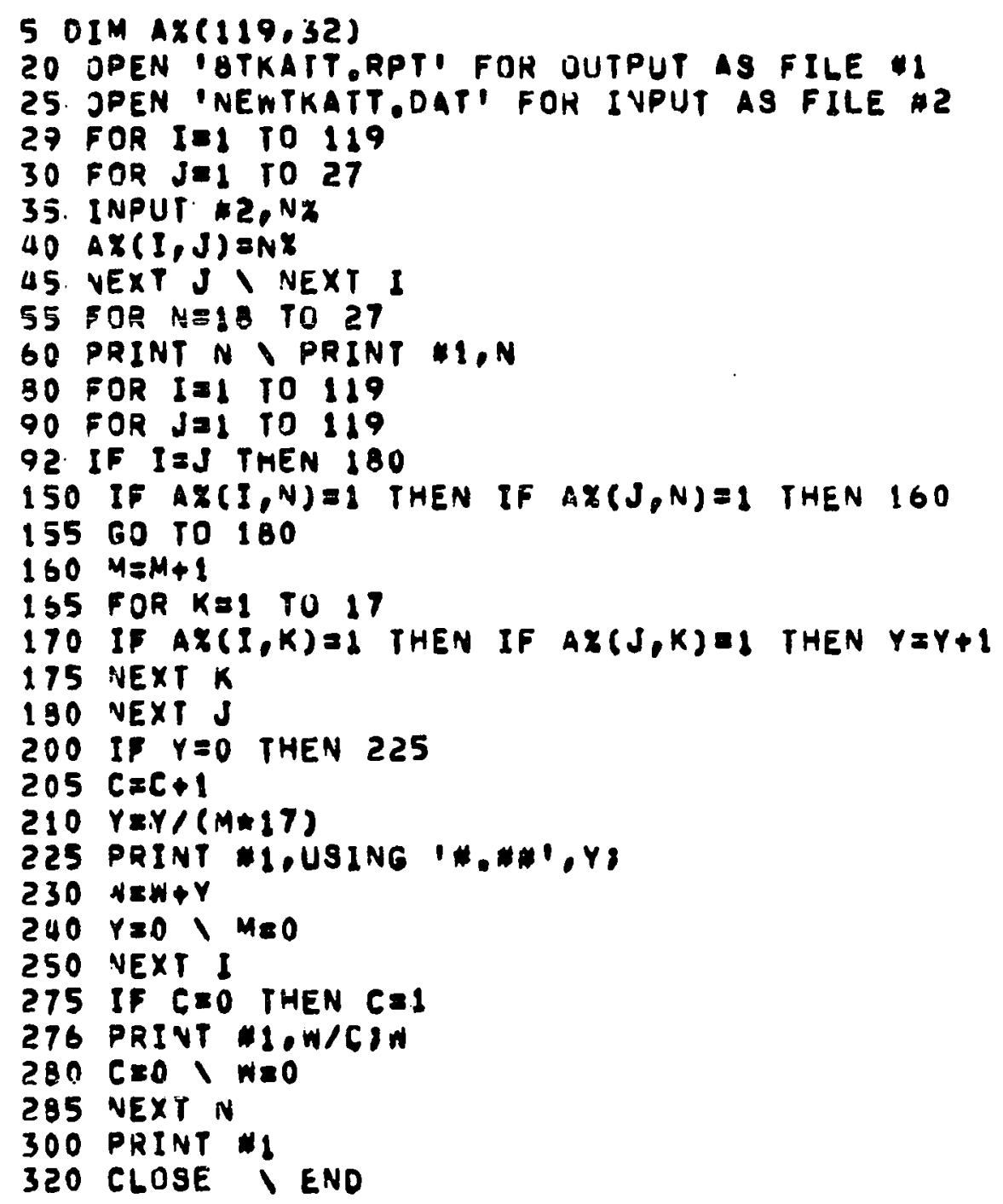


5 DIM AX( \&19.32)

20 OPEN '7TKATT.RPTI. FOR OUTPUT AS FILE

25. OPEN INEWTKATT.DATI. FOH ENPUTAS DILE WZ

29 FOR IEI TO 119

30. FOR JEI TO 27

35. INPUT $2, N X$

$40 \quad A X(I, J)=N X$

- AS NEXT J I NEXT I

55 FOR NEIA TO 27

GO PRINT $N$ I PRINT $1, N$

BO FOR IEI TO 119

Q0 FOR JEL TO 119

92 IF IEJ THEN 180

150 IF AX(I,N)CDAX (J,N) THEN 160

15560 TO 280

$160 \mathrm{MEM}+1$

165 FOR KE1 TO 17

170 IF $A X(I, K)=1$ THEN IF $A X(J, K)=2$ THEN $Y=Y+1$

175 NEXT $K$

180 NEXT $J$

200 IF $Y=0$ THEN 225

$205 C=C+1$

510 Ye.Y $(M \times 17)$

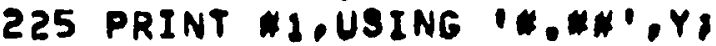

$230 W=W+Y$

$240 \quad Y=0$ I $M=0$

250 NEXT 1

275 IF CEO THEN CEI

276 PRINT $1 . W / C I N$

280 CED I $W=0$

$2 B 5$ NEXT N

300 PRINT 1

320 CLOSE I ENO 


\section{DIM $A \times(119.32)$}

20 OPEN ITTKATT.RPT\%. FOR OUTPUT AS FILE MI

25. OPEN 'NENTKATT.DAT' FOR INPUT AS FILE 2

29 POR IEI TO 189

30 FOR Jad TO 27

35. INPUT M2,NX

40. $\triangle X(I, J)=N X$

45. NEXT J I:NEXT I

55. FOR NEIB TU 27

60. PRINT N I PRINT $11, N$

80 FOR IEI TO 119

90 FOR JEI TO 119

92. IF IJU THEN 180

150 IF AX(I,N)SSAX (J,N) THEN 160

15560 TO 180

$160 \mathrm{MEM}+1$

165 FOR KaS TO 17

170 IF $A X(I, K)=I$ THEN IF $A X(J, K)=1$ THEN $Y=Y+1$

175 NEXT K

180 NEXT $J$

200 IF $Y=0$ THEN 225

$205 C a C+1$

$210 \mathrm{YaY} /(M+17)$

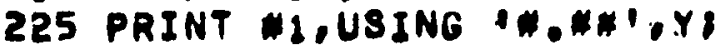

$230 W=W+Y$

$240 \quad Y=0$ \MEO

250 NEXT I

275 IF $C=0$ THEN $C=1$

276 PRINT MIOW/CBN

$280 \quad C=0 \backslash N=0$

285 NEXI N

300 PRI HT

320 CLOSE I END 
5 DIM AX(119,32)

20 OPEN ISTKATT.RPTI.FOR OUTPUT AS FILE $I$

25. OPEN 'ALLCASE.DAT' FOR INPUT AS FILE ZZ

29 FOR IEI TO 118

30 FOR JEI TO 27

35 INPUT $22, N X$

$40 \quad A X(I, J)=N X$

45 NEXT.J I NEXT I

55 FOR NEIO TO 27

60 PRINT $N$ I PRINT $11, N$

BO FOR IEI TO 118

QO FOR JEI TO 128

92 IF IOJ THEN 180

150 IF AX(I,N)=I THEN IF $A X(J, N)=1$ THEN 160

15560 To 180

$160 \mathrm{M}=\mathrm{M}+1$

165 FOR KFI TO 17

170 If $A X(I, K)=1$ THEN IF $A X(J, K)=1$ THEN $Y=Y+1$

175 NEXT K

180 NEXT J

200 IF $Y=0$ THEN 225

$205 C=C+1$

$210 Y=Y /(M * 17)$

225 PRINT 1. USING IN.WN',YI

$230 W E W+Y$

240 Yan $M=0$

250 NEXT I

275 IF. CEO THEN $E \approx I$

276 PRINT HI,W/CIW

280 CED I WOO

285 NEXT N

300 PRINT TI

320 CLOSE I END 


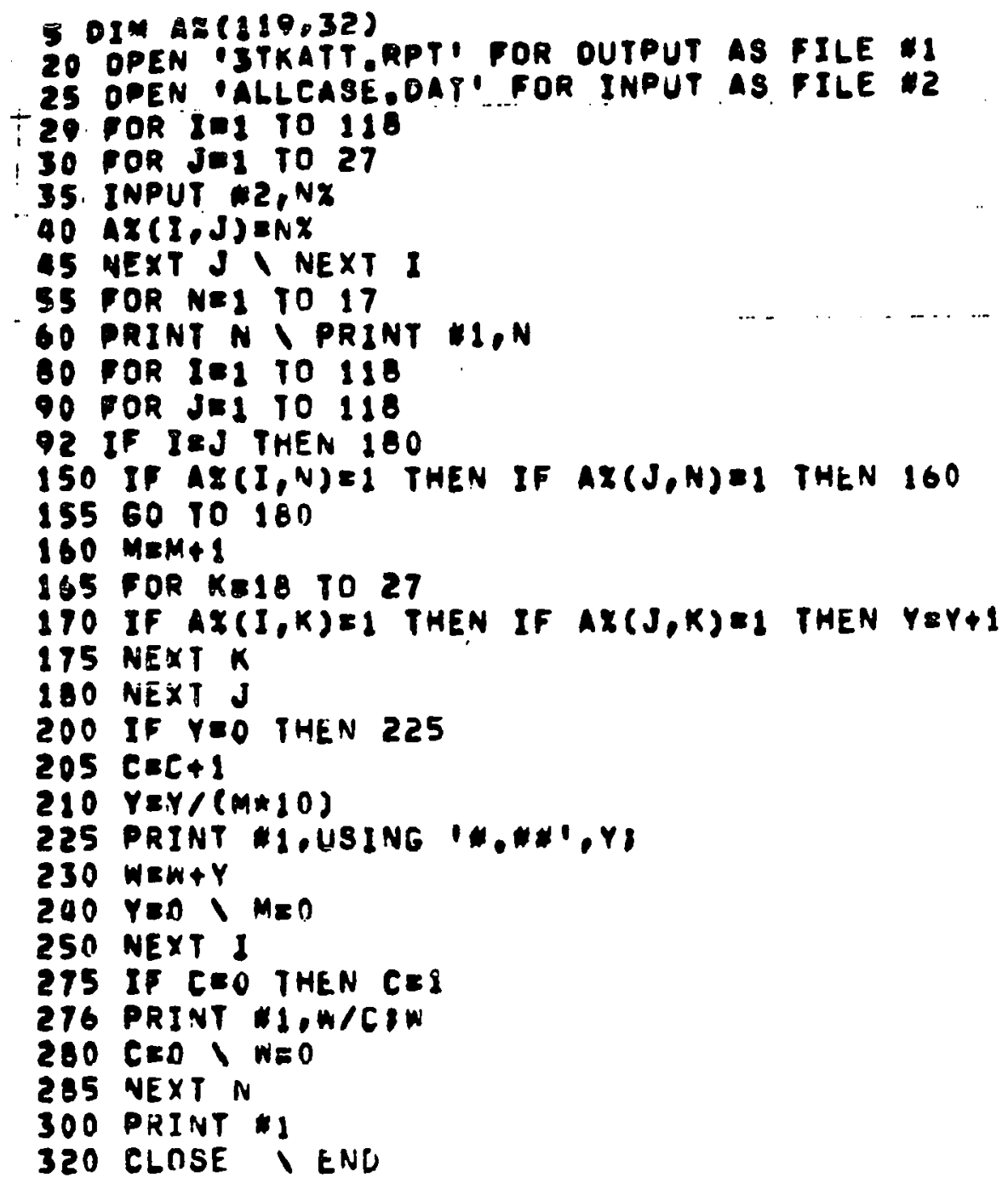




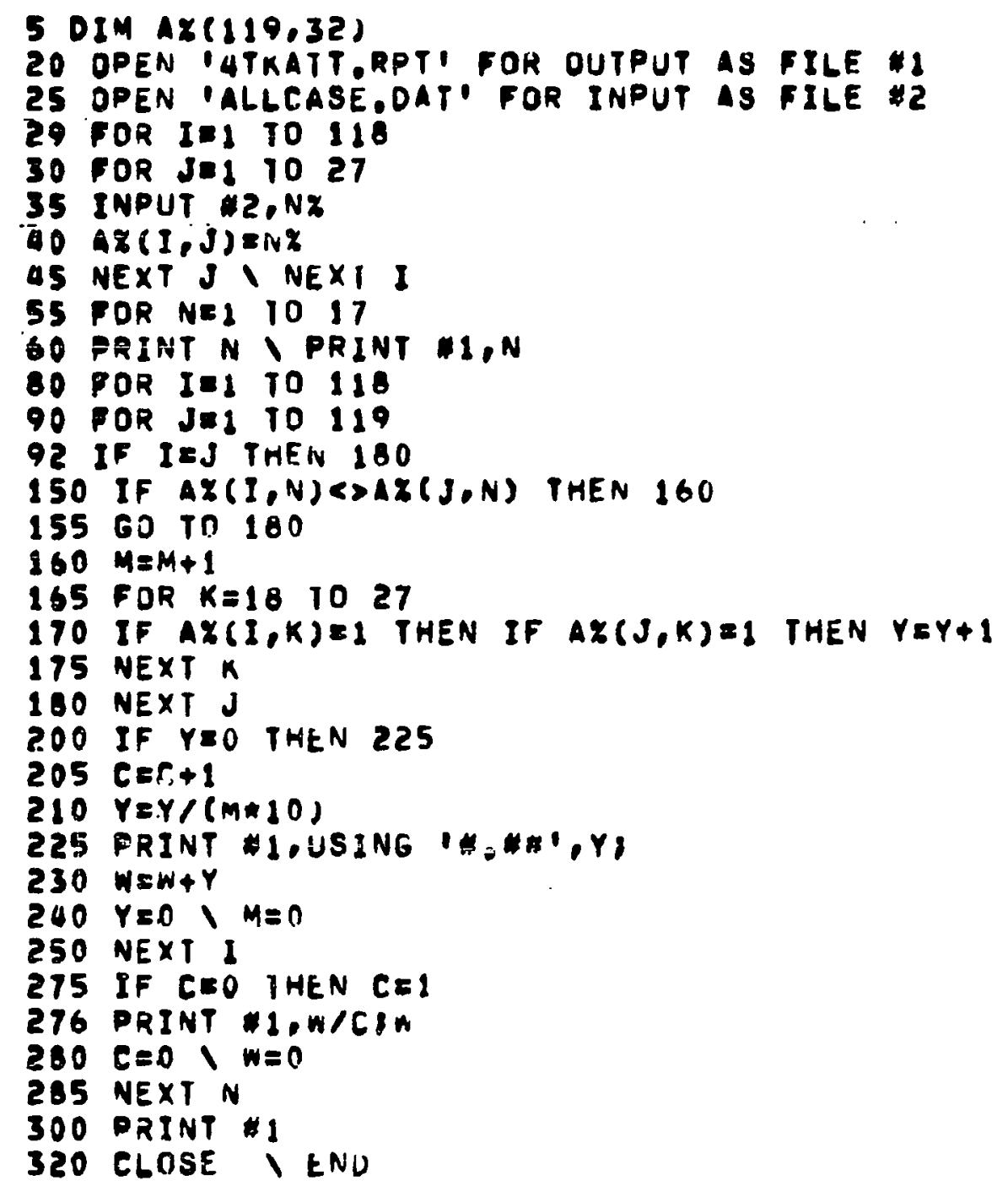




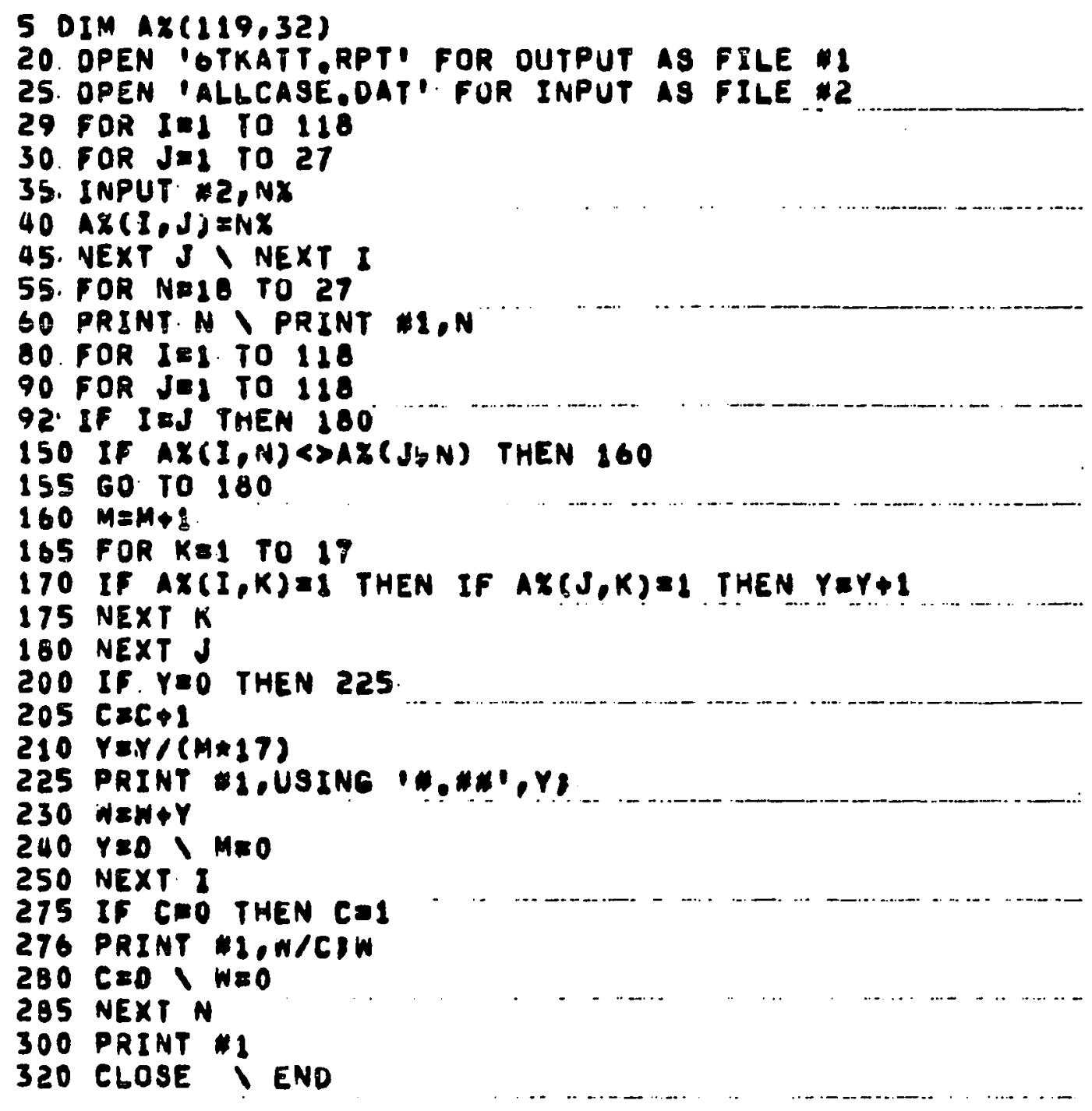




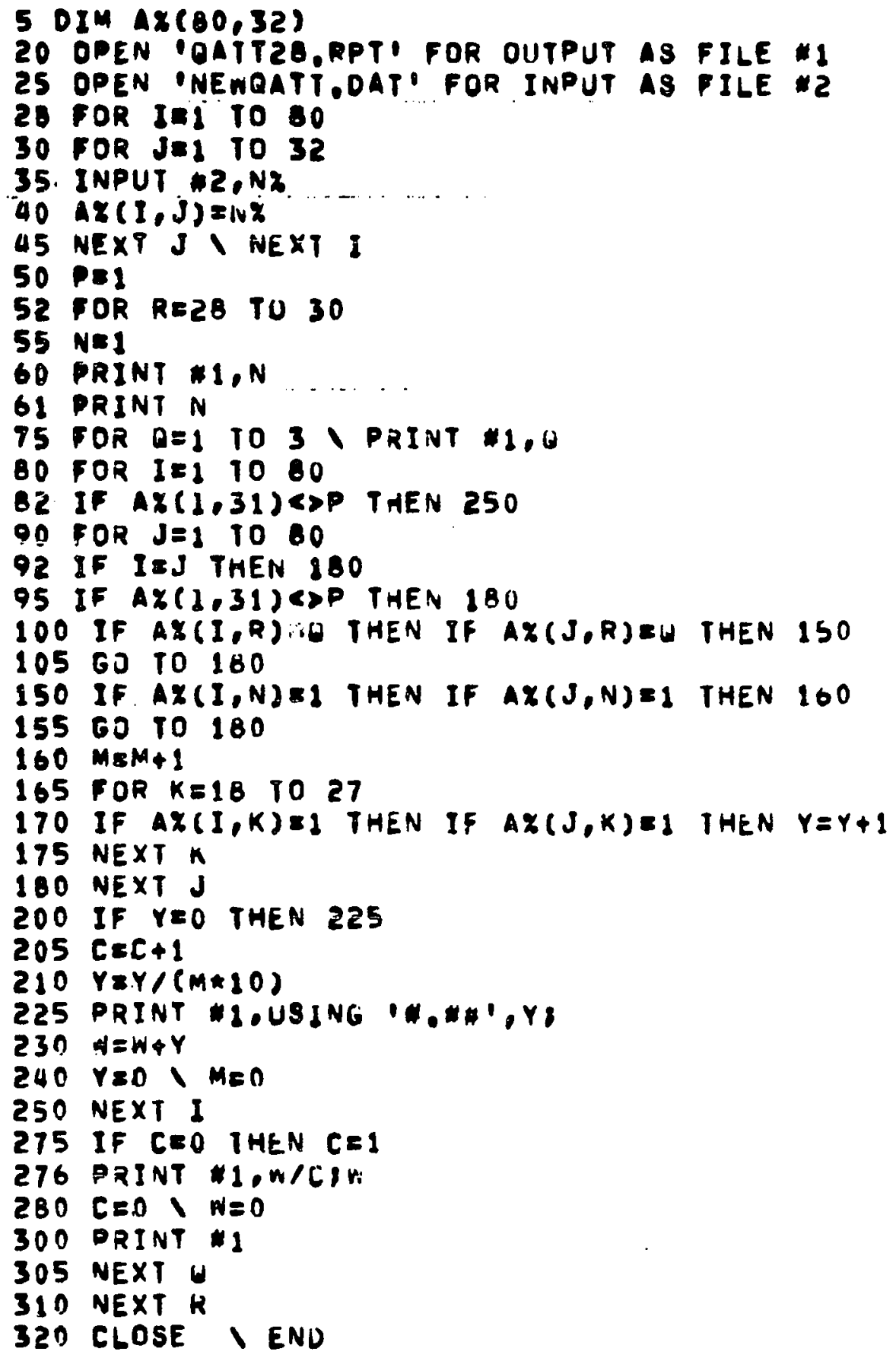




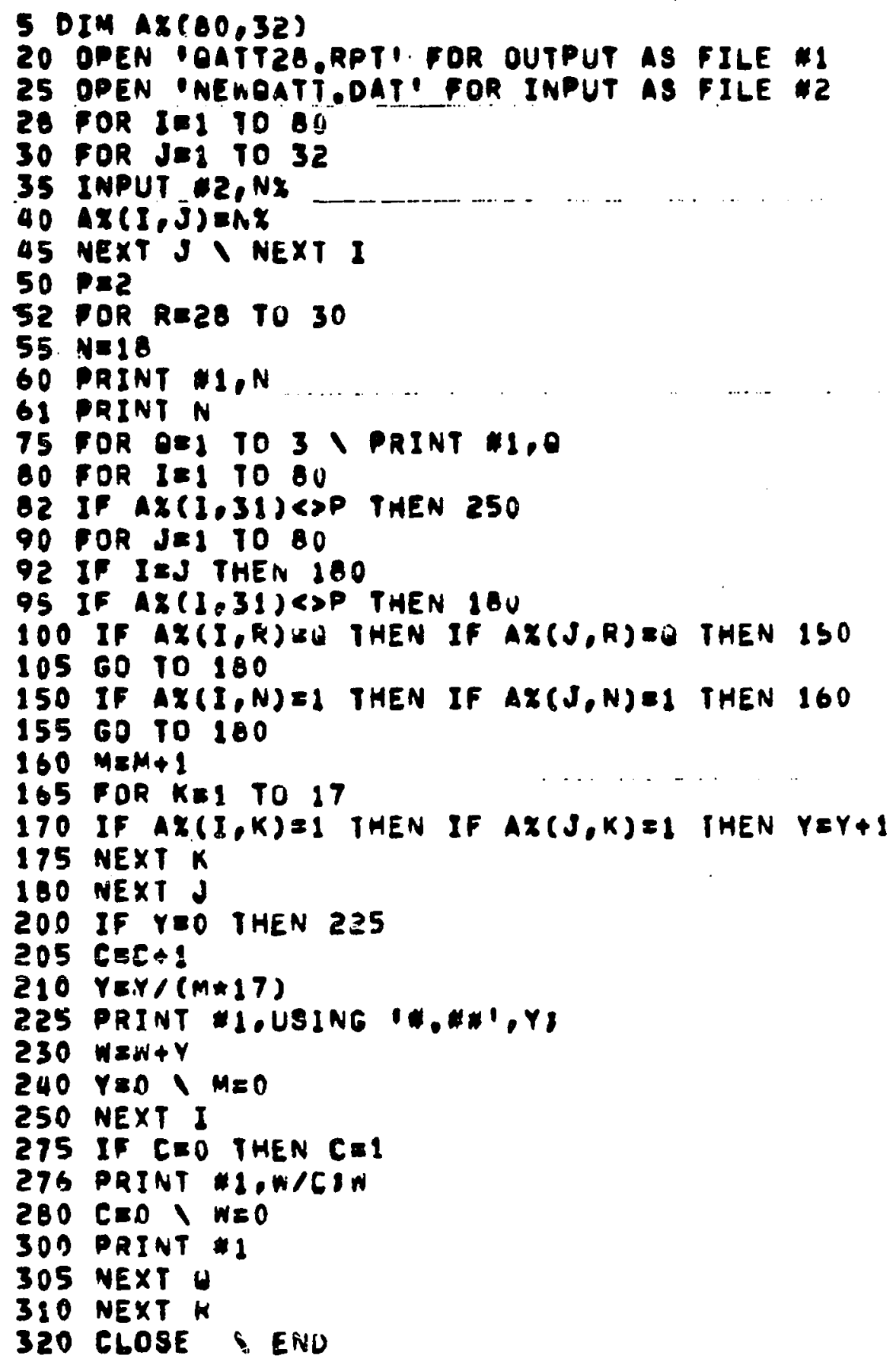


APPEHDIX D

SAHPLE QUESTIOHAIRE AND CODIHG ILLUSTRATIOH? 
QUESTIONNAIRE

Please return to Laura Doyle

$\times 4820$ del. sta. 58-667

The following questions are part of a PhD thesis on business strategy planning. Please don't spend more than 10 minutes reading and answering the following questions. Thank you for participating.

The following paragraphs describe two situations and ask for your input or advice.. Please read each paragraph and note your suggestions or response.

\section{A The situation is this:}

"We estimate the overall"eks" market is' growing at about 25\%/year. Our share is about $5 \%$ in the overall market and about $20 \%$ in the segments we specially target. These segments are also growing at $25 \% / y e a r$. The competition is small, specialized and fragmented. Our customers are two basic types: $70 \%$ OEM and $30 \%$ end-user. Our primary business strengths are the skill and experience of our product design team and our reputaticn for high quality products, and our strategic position within the company. The company expects us to put together a long range business plan which will describe a strategy for becoming more profitable and for gaining a $20 \%$ share of the total "eks" market."

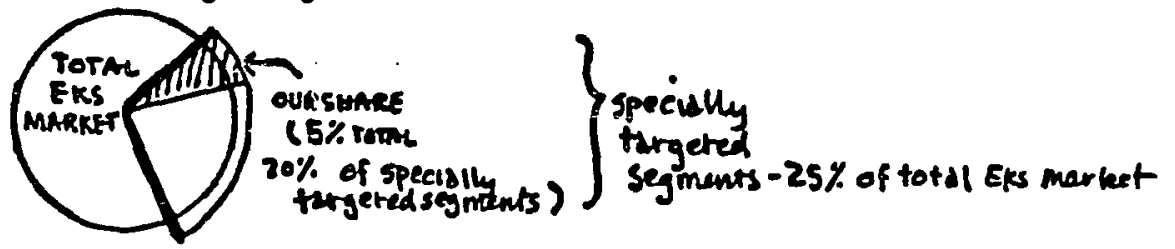

What STRATEgies SHOULD WE LOOK AT FOR POSSIBLE IEACLUSION IN OUR PLAN? 
QUESTIONNAIPE-P2

please return to

Laura Doyle 58-667

$B$ A direct report comes to you with the following proposal:

"We could develop a state-of-the-art 'isodriver' which we would market not only to our current customers but also to the liner and filler industry. We could pay for this development effort by reducing manufacturing costs on our current line."

Your response is: "That approach could work - but only if we were operating under the following conditions: ..."

WHAT CONDITIONS MOULD YOU LIST?

1. How many years have you worked at

$<8$ years _ $8-15$ years 215 years

2. In which area do you feel you have the most experience and training?

_ gengineering business_manufacturing __other (what? marketing

3. What position do you now hold?

general manager

manager of a functional area (je. marketing, manufacturing, etc.)

other (what? 
QUESTIONNAIRE

Please return to Laura Doyle

$x$ fong del. sta. 58-607

6334

Mi

The following questions are part of a PhD thesis on business strategy planning. Please don't spend more than 10 minutes reading and answering the following questions. Thank you for participating.

The following paragraphs describe two situations and ask for your input or advice. Please read each paragraph and note your suggestions or response.

\section{A The situation is this:}

"He estimate the overall"eks" market is. growing at about 25\%/year. Our share is about $5 \%$ in the overall market and about $20 \%$ in the segments we specially target. These segments are also growing at $25 \% / y e a r$. The competition is smail, specialized and fragmented. Our customers are two basic types: 70\% OEM and 30\% end-user. Our primary business strengths are the skill and experience of our product design team and our reputation for high quality products, and our strategic position within the company. The company expects us to put together a long range business plan which will describe a strategy for becoming more profitable and for gaining a $20 \%$ share of the total "eks" market."

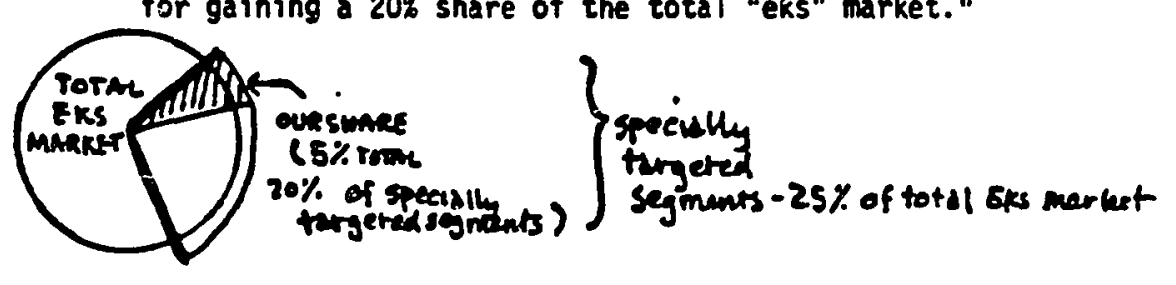

WHAT STRATEGIES SHOULD WE LOOK AT FOR PCSSIBLE INCLUSION IN OUR PLAN?

Pick product opportunities closest to our skills and experience in the rest of the market keeping in mind also our marketing channels' and Sales channels' match to those new product opportunities us tho ones we are already in. (conservative approach.)

(25) Libenal appraach (my preference) pick a totally new segment and dosign a product better than onyone elses. Se couse of our strengths and unbiases it will most likely lee a sungees 


\section{QUESTIONNAIPE-P2 \\ please return to \\ Laura Doyle 58-607 \\ 671}

$B$ A direct report comes to you with the following proposal:

"We could develop a state-of-the-art 'isodriver' wich we would market not only to our current customers but also to the liner and filler industry. He could pay for this development effort by reducing manufacturing costs on our current line."

Your response is: "That approach could work - but only if we were operating under the following conditions: ..."

WHAT CONDITIONS WOULD YOU LIST?
new product profit should be Larger than for the
old peoducts profit t the development cost of the
new product (a) calculate old profit with 17 Od products profit the the prodentate old profit with If the total profit (including the reduced mifs cost) is more tha the ne profit prodect it is not worthd

1. How many years have you worked at Tektronix?

2

2 $\longrightarrow<8$ years $\quad$ 8-15 years $\longrightarrow 15$ years

2. In which area do you feel you have the most experience and training?

(1)

$x$ engineering general business manufacturing marketing

3. What position do you now hold? general manager

+ manager of a functional area (ie. marketing, manufacturing, etc.) other (what? 


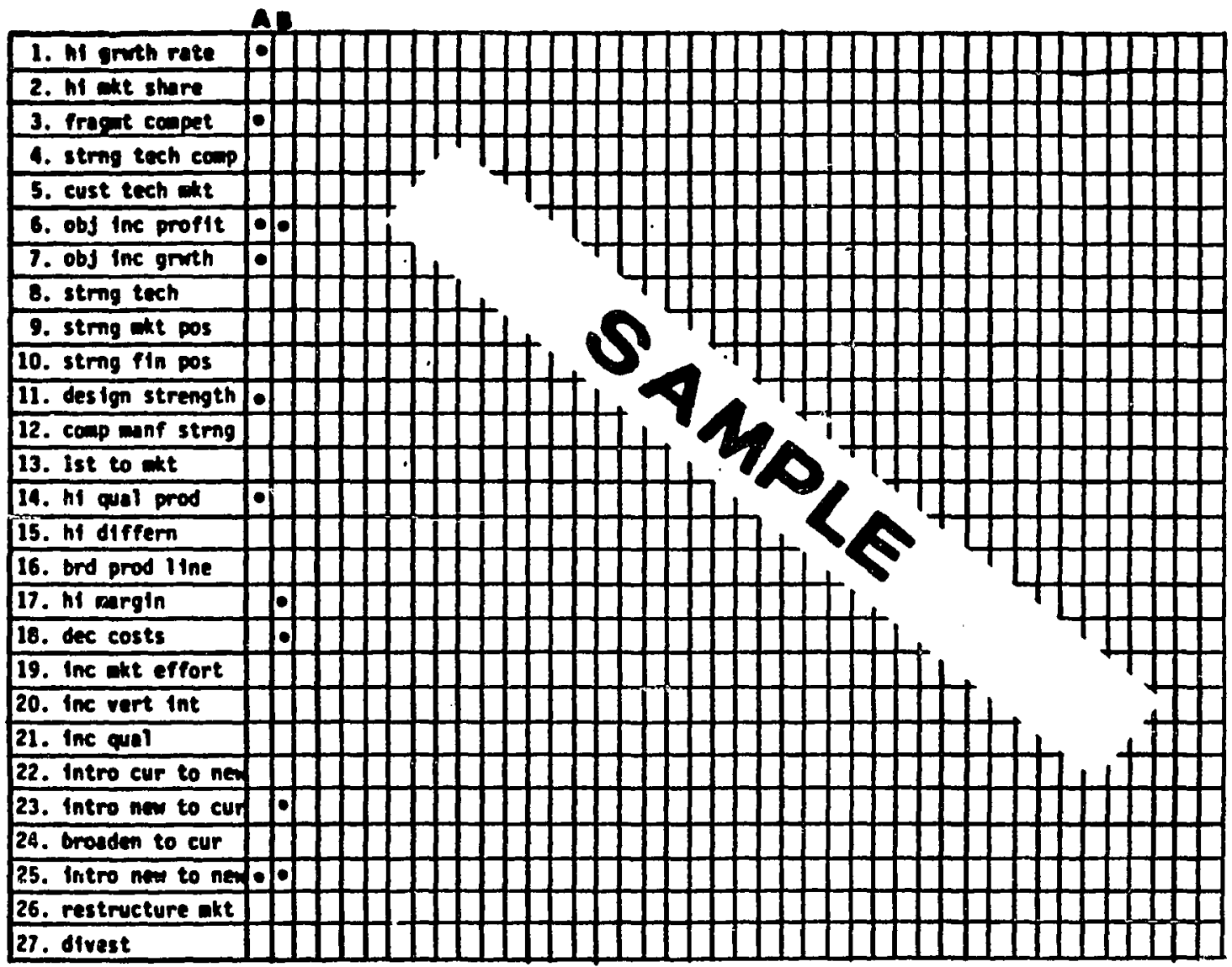


APPEISDIX E

CASE STUDY REFERENCES AHD CODED COITTEIJT DATA 
CASE STUDIES FROM ELECTRONIC BUSINESS

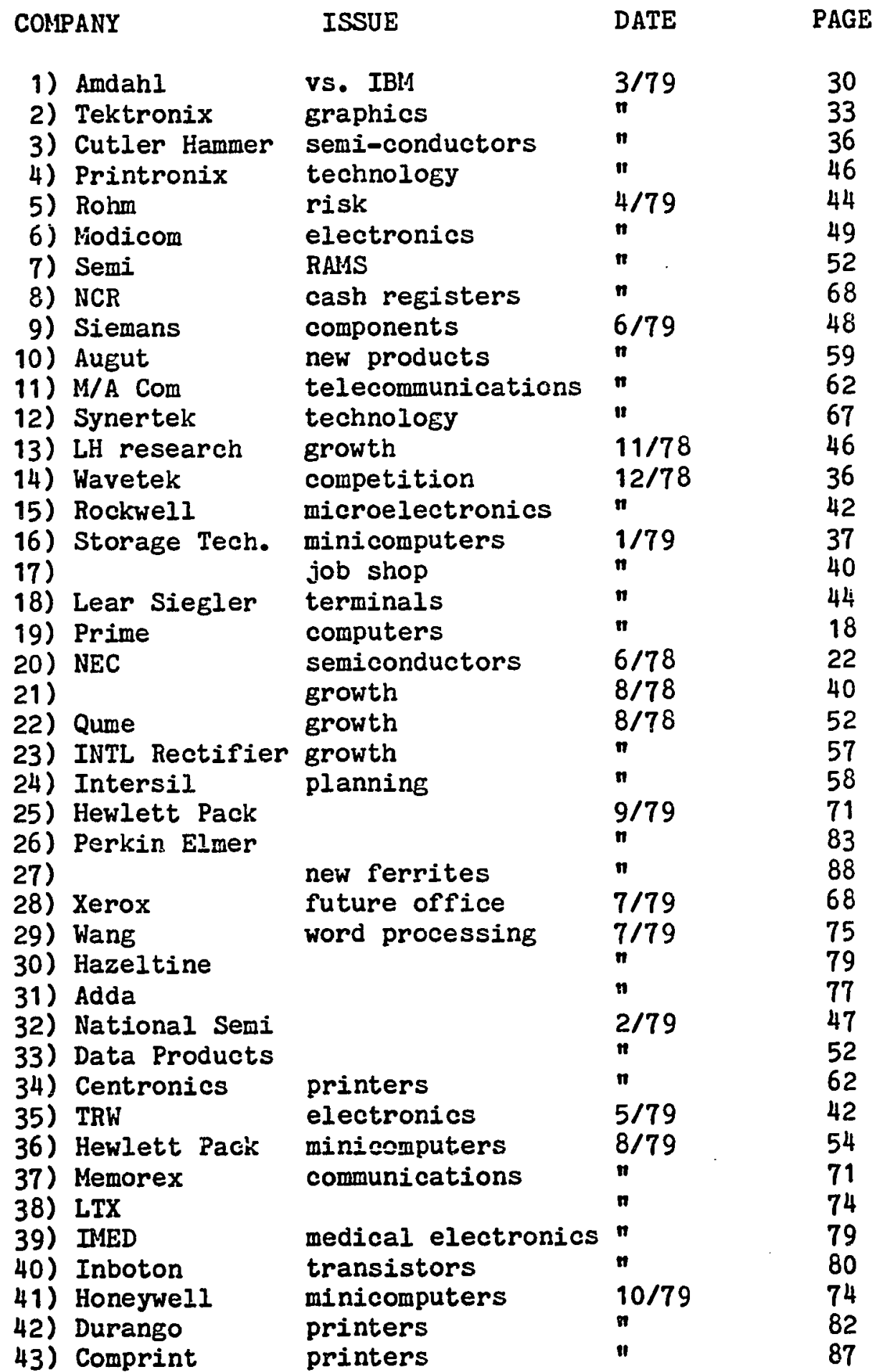




$\begin{array}{llll}\text { 44) } & \text { innovation } & 9 / 78 & 18 \\ \text { 45) Unitrode } & & \text { " } & 23 \\ \text { 46) Biomation } & \text { medical electronics } & \text { n } \\ \text { 47) Cipherdata } & & 10 / 78 & 30 \\ \text { 48) Remex } & \text { new Narkets } & n & 37 \\ \text { 49) Sanders } & \text { printers } & n & 44 \\ \text { 50) Univac Electric } & 12 / 79 & 46 \\ \text { 51) Fluke Trendar } & n & \end{array}$

\section{CASE STUDIES FROM BUSINESS WEEK}

\begin{tabular}{|c|c|c|c|}
\hline COLIF & PANY & DATE & PAGE \\
\hline 52) & Allen Group & $5 / 21 / 79$ & 108 \\
\hline 53) & Philip Morris & $4 / 2 / 79$ & 66 \\
\hline 54) & Hercules & $4 / 3 / 78$ & 94 \\
\hline 55) & Gillette & $n$ & n \\
\hline 56) & Kaufman Broad & $10 / 29 / 79$ & $\prod_{n}^{120}$ \\
\hline $\begin{array}{l}57) \\
58)\end{array}$ & $\begin{array}{l}\text { Gerber Scientific } \\
\text { Phillips }\end{array}$ & $10 / 2 / 78$ & 64 \\
\hline 59) & Green Giant & "1 & n \\
\hline 60$)$ & Narco & $11 / 5 / 79$ & 145 \\
\hline 61) & McDonnel Douglas & $10 / 23 / 78$ & 88 \\
\hline $\begin{array}{l}62) \\
62)\end{array}$ & US Steel & $10 / 9 / 78$ & $\begin{array}{l}68 \\
n\end{array}$ \\
\hline 64) & Waterford Glass & $\mathbf{n}$ & $n$ \\
\hline 65) & Gerber & $10 / 16 / 78$ & 82 \\
\hline 66) & Celanese & $10 / 8 / 79$ & 116 \\
\hline $\begin{array}{l}\text { 67) } \\
68)\end{array}$ & $\begin{array}{l}\text { Puritan Fashions } \\
\text { World Airways }\end{array}$ & $\begin{array}{l}8 / 13 / 79 \\
6 / 25 / 79\end{array}$ & $\begin{array}{l}68 \\
110\end{array}$ \\
\hline 69$)$ & Amstar & n & i \\
\hline 70) & Pitney Bowes & $n$ & $n$ \\
\hline 71) & Hoover & $6 / 18 / 79$ & 110 \\
\hline 72) & Holiday Inn & $7 / 18 / 79$ & 158 \\
\hline 73) & Dunn Bradstreet & $8 / 27 / 79$ & 72 \\
\hline 74) & Jennaire & $12 / 18 / 78$ & 73 \\
\hline 75) & Dean Foods & $12 / 18 / 78$ & n \\
\hline 76$)$ & us steel & $9 / 17 / 79$ & 78 \\
\hline 77) & Texas Instrument & $9 / 18 / 78$ & 66 \\
\hline $\begin{array}{l}\text { 78) } \\
79)\end{array}$ & $\begin{array}{l}\text { Bell \& Howell } \\
\text { Consolid. Cigar }\end{array}$ & $7 / 30 / 79$ & $\begin{array}{l}88 \\
n\end{array}$ \\
\hline $\begin{array}{l}80) \\
81)\end{array}$ & $\begin{array}{l}\text { Ralston Purina } \\
\text { Toro }\end{array}$ & $9 / 10 / 79$ & $\ln _{n}^{112}$ \\
\hline $\begin{array}{l}\text { 82) } \\
83)\end{array}$ & $\begin{array}{l}\text { Diners Club } \\
\text { Checker Motors }\end{array}$ & $1 / 15 / 79$ & $\ln _{n}^{100}$ \\
\hline 8 & olivetti & $2 / 12 / 79$ & 93 \\
\hline 85) & Alexander Baldwir & $n n$ & n \\
\hline $\begin{array}{l}\text { 86) } \\
87)\end{array}$ & $\begin{array}{l}\text { Perrier } \\
\text { GAF }\end{array}$ & $1 / 22 / 79$ & 64 \\
\hline 88) & Peoples Drug & $n$ & $\mathbf{n}$ \\
\hline
\end{tabular}




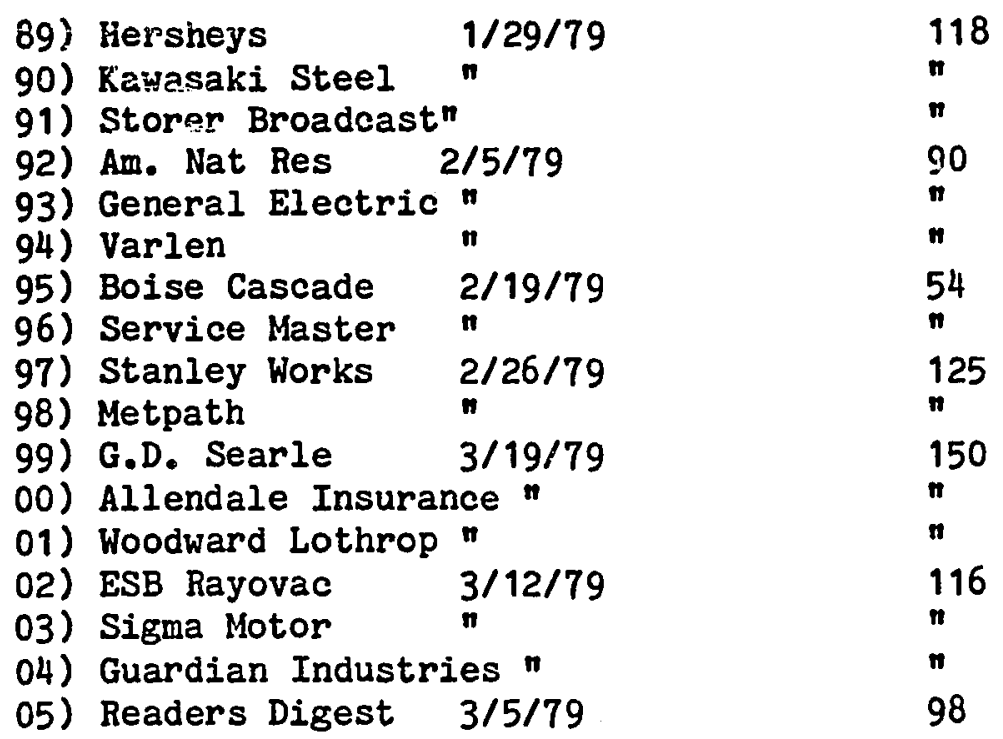




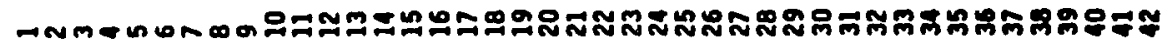

\begin{tabular}{|c|c|c|c|c|c|c|c|c|c|c|c|c|c|c|c|c|c|c|c|c|c|c|c|c|c|c|}
\hline 1. hi gruth rate & $\bullet$ & 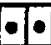 & .10 & .10 & .1. & & & $1 \bullet$ & .10 & .1. & .10 & T.:. & .1 .1 & 0.10 & $1 \cdot 10$ & 1.10 & $\bullet$ & Te & 1 & $\bullet$ & 0. & & & 0.10 & & \\
\hline 2. hi mkt share & & $\bullet$ & $\bullet$ & 0 & 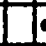 & $\bullet$ & $\bullet$ & & & $\bullet$ & & & & & 1 & & & & & & 0 & & & 0 & & \\
\hline 3. fragmt compet & & $\bullet$ & . & $\cdot 0$ & • & $\bullet$ & & 10 & 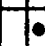 & & & & & $\bullet$ & & 0 & & & & & & & & & & \\
\hline 4. strng tech comp & 10 & $\bullet$ & & & $\bullet$ & & & & & & 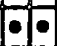 & & $\bullet$ & $\bullet$ & & & $\bullet$ & & $\bullet$ & $\bullet$ & & & .0 & & $\bullet$ & \\
\hline 5. cust tech mkt & & $\bullet$ & & & & 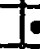 & $\bullet$ & $\bullet$ & $\bullet$ & & & & & & 6 & & - & $\bullet$ & & & & & 6 & & & \\
\hline 6. obj inc profit & & & & $\bullet$ & & & & & & $\bullet$ & $\bullet$ & $\bullet$ & & & • & 0 & $\bullet$ & $\bullet$ & & & & & & & $\bullet$ & \\
\hline 7. obj inc grwth & 6 & & $\bullet$ & & & 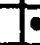 & & & $\theta$ & & 6 & 10 & 0 & $\bullet$ & & & - & e & & $\bullet$ & & & & & $\bullet$ & \\
\hline 8. strng tech & $\bullet$ & & $\bullet$ & & 1 & & & 0 & $\bullet$ & & $\bullet$ & & $\bullet$ & 0 & $\bullet$ & 0. & $\bullet$ & 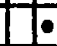 & .0 & 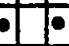 & $\bullet$ & $\bullet$ & & & & \\
\hline 9. strng nkt pos & 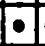 & $\bullet \bullet$ & & 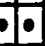 & & & & $\bullet$ & $\bullet$ & 0 & & & & & & & $\bullet$ & 6 & 0 & & $\bullet$ & & & 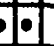 & - & \\
\hline 10. strng fin pos & & $\bullet$ & & & & & & $\bullet$ & & & & & & 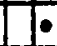 & & & & & & $\bullet$ & & & & & & \\
\hline 11. design strength & $\bullet$ & $\bullet$ & -10 & + & & & & & $\bullet$ & +1 & & & 101 & & $\bullet$ & 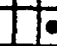 & - & & 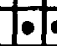 & & 0 & $\bullet$ & & 0 & $\bullet$ & \\
\hline 12. comp manf strng & $\bullet$ & $\bullet$ & & & $\bullet$ & & & & $\bullet$ & & .0 & & $\bullet$ & $\bullet$ & & & & & & $\bullet$ & & & & & & \\
\hline 13. Ist to $\mathrm{mkt}$ & $\bullet$ & $\bullet$ & & & 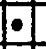 & & $\bullet$ & & & $\cdot$ & $\cdot 0$ & & & & $\bullet$ & & & & 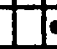 & & $\bullet$ & & & & & \\
\hline 14. hi qual prod & $\bullet$ & & $\bullet$ & 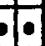 & .1 & - to & &. & $\cdot 0$ & & $\bullet$ & & $\bullet$ & e & $\bullet$ & & & & & & & & $\bullet$ & 6 & - & \\
\hline 15. hi differn & $\bullet$ & $\bullet$ & 0 & 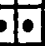 & $\bullet$ & & 0 & & e & & $\bullet$ & to & $\bullet$ & & $\bullet$ & 1.6 & $\bullet$ & 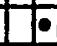 & & & $\bullet$ & 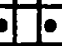 & $\bullet$ & & 6 & \\
\hline 16. brd prod line & & $\bullet$ & & & & 6 &. & 0 & & & & 10 & & & - & & $\bullet$ & & $\bullet$ & & & & & & & \\
\hline 17. hi margin & $\bullet$ & $\bullet$ & & & & & & & & & & & & & & & & & & & & & & & & \\
\hline 18. dec costs & & & 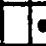 & & & 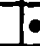 & 0 & & 1 & & & & 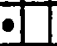 & & 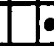 & 0 & & $\bullet$ & & $\bullet$ & $\bullet$ & & & & $\bullet$ & \\
\hline 19. inc akt effort & & & & & & $\bullet$ & & & & & & $1 \bullet$ & $\bullet$ & $\bullet$ & & & & $\bullet$ & & $\bullet$ & & $\bullet$ & $\bullet$ & & & \\
\hline 20. inc vert int & $\bullet$ & & & & 01 & & 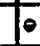 & 0 & & & & & $\theta$ & & 0 & 0 & & & & 00 & 10 & 0 & & & & \\
\hline 21. Inc qual & 6 & & & & & & & & & & & & & & & & $\bullet$ & 6 & 0 & $\bullet$ & & $\bullet$ & & & & \\
\hline 22. intro cur to new & & & $\bullet$ & to & $\bullet$ & & & & $\bullet$ & $\bullet$ & $\bullet$ & - & 0 & $\bullet$ & $\bullet$ & 0 & 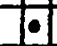 & 0 & & $\bullet$ & $\bullet$ & - & & 0 & & \\
\hline 23. Intro new to cur & & $\bullet$ & & & & & & e & & & $\bullet \cdot$ & & 6 & & $\bullet$ & - & $\bullet$ & $\bullet$ & & $\bullet$ & & & & & & \\
\hline 24. broaden to cur & & $\bullet$ & & & 18 & & 10 & 0 & 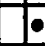 & & & e- & - & $\bullet$ & 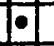 & 0 & & & $E$ & & $\bullet$ & & & & & \\
\hline 25. Intro new to new & & - & & & & & $\bullet$ & & & 10 & . & & & & & & $\bullet$ & $\bullet$ & & & & 10 & .10 & & & \\
\hline 26. restructure nkt & 1 & $\bullet$ & & & & & & & & & & & & & & & & & & & & & & & & \\
\hline 27. divest & & & & & & & & & & & & & & & & & & & & & & & & & & \\
\hline
\end{tabular}




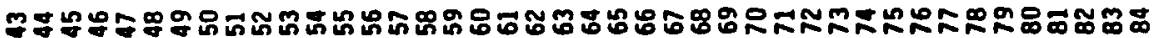

\begin{tabular}{|c|c|c|c|c|c|c|c|c|c|c|c|c|c|c|c|c|c|c|c|c|c|c|c|c|c|c|c|c|c|}
\hline 1. hi grwth rote & $\bullet$ & & $\bullet$ & & $\bullet$ & & e & & $\bullet$ & & $\bullet$ & & $\cdot \bullet$ & & & & & $\bullet$ & $\cdot \cdot \cdot$ & & & 10 & & 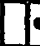 & & 010 & 01 & & \\
\hline 2. hi mkt share & & & $\bullet$ & & & & $\bullet$ & & & & $\bullet \cdot$ & 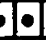 & e & 0 & & & - & $\cdot \bullet$ & $\theta$ & & & 0 & 0 & & & & & & \\
\hline 3. fragnt compet & $\bullet$ & & & & & & & e. & & & & & & 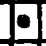 & & & & $\bullet$ & 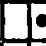 & & & & & 0 & & & & $\bullet$ & \\
\hline 4. strng tech comp & 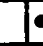 & & $\bullet$ & & & & $\bullet$ & & & & & & & & $\bullet$ & & & e & $\bullet$ & & & $\bullet \cdot$ & 0 & & & $0 \cdot$ & & & $\bullet$ \\
\hline 5. cust tech mkt & & & $\bullet$ & - & & & 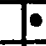 & & $\bullet$ & & & & & & & & & $\bullet$ & & & & & & & & 0 & & & $\bullet$ \\
\hline 6. obj inc profit & & & & & & & $\bullet$ & 0 & & 0 & $\bullet$ & $\cdot$ & & 0 & $\cdot 1 \cdot$ & 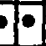 & $\bullet$ & - & $\bullet$ & & & $\bullet$ & & & & & & & $\bullet$ \\
\hline 7. obj inc grwth & & & & & 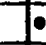 & $\bullet$ & 0 & & & & & & $\bullet$ & & & 0 & & & & $\bullet$ & $\bullet$ & & $\overline{0}$ & $=1$ & efo & $1 \cdot$ & +e & $\bullet$ & \\
\hline 8. strng tech & & $\bullet$ & $\bullet$ & & $\bullet$ & & & & $\bullet$ & & $\bullet$ & & & & & & & & 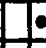 & 0 & & 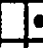 & & & & 0. & & & \\
\hline 9. strng akt pos & & & & - & & 0 & $\bullet$ & 0 & & - & & & - & 0 & 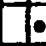 & & $1 \bullet$ & $\cdot 1 \cdot$ & $\bullet$ & & & $\bullet$ & & & 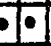 & 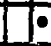 & & & \\
\hline 10. strng fin pos & - & & & & & & & & & & & & & & & & & & & & & & & & & je & & & \\
\hline 11. design strength & 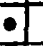 & $\bullet$ & $\bullet$ & & & & & & $\bullet$ & & - & & & & & & & & $\bullet$ & $\bullet$ & & & $\bullet$ & & & & & & \\
\hline 12. comp manf strng & & & & & & & & & & & & & & & & & & & & & & $\theta$ & & & & & & & \\
\hline 13. Ist to mkt & 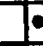 & & $\bullet$ & & & & & & 0 & & & & & & & & & & & 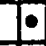 & & & 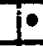 & & & & & & \\
\hline 14. hi qual prod & & $\bullet$ & & & & & & & $\bullet$ & & & & - & & & & & & 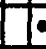 & 0 & -1) & & & & & 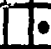 & & & \\
\hline 15. Hi differn & & 01 & 010 & 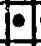 & $\bullet$ & & $\bullet$ & & & & $\bullet$ & & & & & 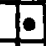 & & & 5 & $\bullet \cdot$ & & & & & & & 10 & & \\
\hline 16. brd prod line & & & & & & & $\bullet \cdot$ & & & $\bullet$ & & & & $\bullet$ & & & $\bullet$ & $\cdot 1$ & $\bullet$ & $\bullet$ & & & & & $\bullet$ & $\bullet$ & & & \\
\hline 17. hi margin & & & & & & & & & & & & & & & & & & & & & & & & & & & & & \\
\hline 18. dec costs & $\bullet$ & 6 & & & & & $\bullet$ & & & 0 & 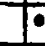 & & & & $\bullet$ & $\bullet$ & $\bullet$ & & $\bullet$ & & . & 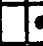 & & - & & 10 & 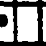 & & \\
\hline 19. Inc mkt effort & & el & & & 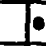 & 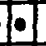 & $\bullet$ & & & 10 & & & $\bullet$ & & 2 & & & & & & 10 & & & $\bullet$ & $\bullet \cdot$ & 10 & 0 & $\bullet$ & \\
\hline 20. Inc vert int & & & & & & & & & & & & & & & & & & & & & & & & & & 0 & & & \\
\hline 21. inc qual & & & & & & & & $\theta$ & & & & & & & 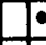 & & & & & & 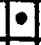 & & & & & $\bullet$ & $\bullet$ & & \\
\hline 22. intro cur to new & & e & & & 6 & & & & & & & & & & & $\bullet$ & & & & & & & & & & 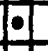 & $\theta$ & & \\
\hline 23. intro new to cur & & & & $\bullet$ & 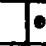 & & & & & 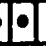 & & & 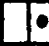 & $1 \cdot 1$ & & & & $\bullet$ & $\bullet$ & & 10 & 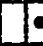 & & & $\bullet$ & & & & 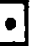 \\
\hline 24. broaden to cur & & & & & & & - & & & & 0 & & & & & & $\bullet$ & & & & & & & & & 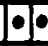 & & $\bullet$ & \\
\hline 25. Intro new to new & & 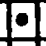 & & & $\bullet$ & & & $\bullet$ & $\bullet$ & 0 & - & $\theta$ & $\cdot$ & & 0 & & & & & & - & & $\bullet$ & $\bullet$ & & & & $\bullet$ & \\
\hline 26. restructure akt & & & - & & & - & & & & & & & & & & & & & & & & & & & & & & & \\
\hline 27. divest & & & & & & & & & & & $\bullet$ & & & & & & $?$ & & 9 & & & $\bullet$ & & & $\bullet$ & & & & \\
\hline
\end{tabular}




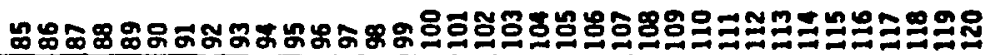

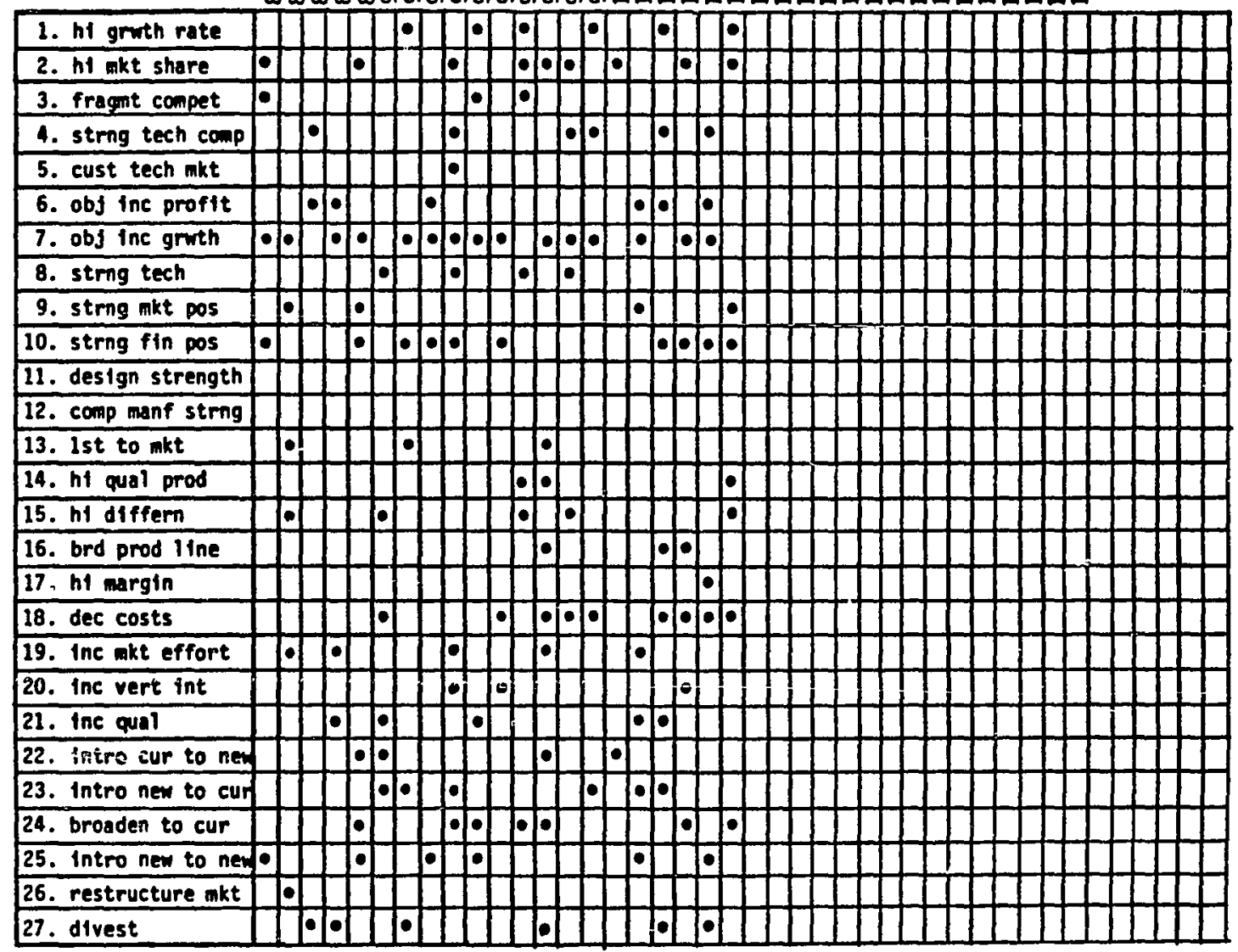

